\title{
Abundance, distribution and trend of the lesser spotted eagle (Aquila pomari- $n a)$ breeding population in Slovakia
}

\author{
Početnost', distribúcia a trend vývoja hniezdnej populácie orla krikl’avého (Aquila pomari- \\ na) na Slovensku
}

\author{
Miroslav DRAVECKÝ, Boris MADERIČ, Ján TOPERCER, Ján KICKO, Štefan DANKO, \\ Dušan KARASKA, Zuzana GUZIOVÁ \& Karol ŠOTNÁR
}

\begin{abstract}
Several estimates of the lesser spotted eagle breeding population in Slovakia were published in 1955-2002. In this study we estimate the breeding population of the lesser spotted eagle by 1997 and 2014. By 1997, the estimated size of the breeding population was 762 pairs. In 2002 an estimate of the population size by 2000 was published at $800-900$ pairs. By 2014 we estimate the breeding population of the lesser spotted eagle in Slovakia at 600-800 pairs and the declining population trend in 2000-2013 at -23\%. Our estimate is supported by the extrapolation from data obtained in 2011-2013 in eight selected Special Protection Areas (SPAs) within a framework of the project LIFE09 NAT/SK/000396 "Conservation of Aquila pomarina in Slovakia". When analyzing abundance, density and trends in the species' entire breeding range in Slovakia we first summarised the numbers of breeding pairs, their densities and trends within the selected SPAs and then explored the differences among them using ANOVA and cluster analysis. For the eight SPAs as a whole $(n=8)$ or partitioned by a grid of the Databank of Slovak Fauna ( $n=119$ squares) we calculated the interval estimates of the mean number of pairs (unweighted and weighted arithmetic means and medians). By summarising these estimates and extrapolating to the species' entire breeding range in Slovakia (c. $28,935 \mathrm{~km}^{2}$ ) while increasing the sample size $(\mathrm{n}=8,9,11$ and 12 SPAs), the size estimates stabilise at a level of 670 (mean with $95 \% \mathrm{LCL}=$ 507 and $95 \% \mathrm{UCL}=834$ ) or 765 (median with $95 \% \mathrm{LCL}=393$ and $95 \% \mathrm{UCL}=841$ ) breeding pairs. The most reliable estimate of the breeding population of the lesser spotted eagle in Slovakia by 2014 is a median of 765 pairs with a $95 \%$ confidence interval from 393 to 841 pairs and an interquartile range from 418 to 835 pairs. We estimate a $23 \%$ decrease in the breeding population during 2000-2013, i.e. a small decrease -1 (20-49\%). Three methods of estimating were used: 1$)$ comparing the numbers of pairs in the selected SPAs between 2000 and 2014 - indicates a decrease of -26\%; 2) comparing the numbers of pairs from long-term monitoring in five areas (orographic units Vihorlatské vrchy Mts, Laborecká vrchovina Upland, Volovské vrchy Mts, Orava and Horné Ponitrie Regions) by the 1990s and 2014 - indicates a decrease of $-20 \%$; 3) comparing the numbers of pairs by 1997 in selected areas within the boundaries of the current SPAs with the number of pairs in the same SPAs by 2014 - indicates a decrease of $-23 \%$. In the eight selected SPAs the estimated decline was even more pronounced, reaching a median trend of $-35 \%$ in the $95 \%$ confidence interval from $-54 \%$ to $+25 \%$. The estimate by 1997 fits in with an increasing trend of published breeding population estimates in Slovakia during 1955-2002. The estimate by 2014 is lower than the estimate by 2000, and for the first time ever a declining trend is recorded. By 2014 the breeding grounds of the lesser spotted eagle in Slovakia embrace an area of c. $28,935 \mathrm{~km}^{2}$. Taking an estimate of $600-800$ breeding pairs, the mean density varies between $2.1-2.8$ pairs.100 km-2.
\end{abstract}

Abstrakt: Odhad početnosti hniezdnej populácie orla krikl'avého na Slovensku bol publikovaný v rokoch 1955-2002 V tejto štúdii odhadujeme početnost' hniezdnej populácie orla krikl'avého k rokom 1997 a 2014 . K roku 1997 bol odhadnutý celkový počet 762 párov. V roku 2002 bol publikovaný odhad početnosti k roku 2000 vo výške $800-900$ párov. K roku 2014 odhadujeme početnost' hniezdnej populácie orla krikl'avého na Slovensku na 600-800 párov a klesajúci trend vývoja populácie $\mathrm{v}$ rokoch 2000-2013 priemerne -23\%. Náš odhad je podložený výsledkami extrapolácie údajov, získaných v rokoch 2011-2013 z ôsmich vybraných chránených vtáčích území v rámci riešenia projektu LIFE09 NAT/SK/000396 „Ochrana orla krikl’avého na Slovensku“. Pri štatistickej analýze početnosti, hustôt a trendov pre celý areál hniezdneho rozšírenia druhu na Slovensku sme vychádzali zo sumarizovaných počtov hniezdnych párov, ich hustôt a trendov vo vybraných územiach a z ich stratifikácie podl'a výsledkov ANOVA a zhlukovej analýzy. Pre 8 chránených vtáčích území vcelku $(\mathrm{n}=8)$ i v členení podl’a kvadrátov Databanky Fauny Slovenska $(n=119)$ sme vypočítali intervalové odhady stredných hodnôt počtu párov (prosté i vážené aritmetické priemery a mediány). Ich sumarizáciou pri postupnom zväčšovaní vzorky ( $\mathrm{n}=8,9,11$ a 12) a extrapoláciou na celý areál hniezdneho rozš́renia druhu na Slovensku (ca $28935 \mathrm{~km}^{2}$ ) sa výsledné odhady stredných hodnôt stabilizovali na úrovni 670 (aritmetický priemer s 95\%LCL = 507 a 95\%UCL = 834) resp. 765 (medián s 95\%LCL = 393 a 95\%UCL = 841) hniezdnych párov. Ako najspol'ahlivejší odhad početnosti hniezdnej populácie orla krikl'avého na Slovensku k roku 2014 vychádza medián 765 párov v $95 \%$-nom intervale spol'ahlivosti od 393 do 841 párov a s medzikvartilovým rozpätím od 418 do 835 párov. Odhadujeme 23 \%-ný pokles celoslovenskej populácie v rokoch 2000-2013, čo predstavuje mierny pokles -1 (20-49 \%). 
Vychádza z troch spôsobov odhadovania: 1) porovnanie počtu hniezdnych párov vo vybraných chránených vtáčích územiach k roku 2000 a 2014 - poukazuje na pokles $-26 \%$; 2) porovnanie počtu hniezdnych párov v piatich dlhodobo monitorovaných územiach orografických celkov Vihorlatské vrchy, Laborecká vrchovina, Volovské vrchy a regiónov Orava a Horné Ponitrie v 90tych rokoch 20. storočia a k roku 2014 - poukazuje na pokles -20 \%; 3) porovnanie počtu hniezdnych párov k roku 1997 vo vybraných územiach $\mathrm{v}$ hraniciach súčasných chránených vtáčích území s počtom hniezdnych párov $\mathrm{v}$ tých istých chránených vtáćích územiach $\mathrm{k}$ roku 2014 - poukazuje na pokles $-23 \%$. V 8 vybraných chránených vtáćích územiach bol štatisticky odhadnutý pokles početnosti hniezdnej populácie $A$. pomarina ešte výraznejší, a to až na úrovni mediánového trendu -35\% v $95 \%$-nom intervale spol'ahlivosti od $-54 \%$ do $+25 \%$. Odhad k roku 1997 zapadá do vzostupného trendu vývoja publikovaných odhadov početnosti hniezdnej populácie druhu na Slovensku v rokoch 1955-2002. Odhad k roku 2014 ukazuje už menší počet hniezdnych párov v porovnaní s odhadom $\mathrm{k}$ roku 2000 a prvýkrát v histórii sa zaznamenáva klesajúci trend. K roku 2014 sa hniezdny areál orla krikl'avého na Slovensku rozprestiera na ploche ca $28935 \mathrm{~km}^{2}$ a pri odhadovanom počte $600-800$ hniezdnych párov je denzita priemerne 2,1-2,8 hniezdnych párov.100 $\mathrm{km}^{-2}$.

Key words: ecology, conservation, population status, research

Miroslav Dravecký, Boris Maderič, Štefan Danko, Zuzana Guziová, Raptor Protection of Slovakia, Kuklovská 5, SK-841 04 Bratislava, Slovakia.E-mail: dravecky@dravce.sk,maderic@dravce.sk, dankostef@gmail.com, guziova@dravce.sk.

Ján Topercer, Comenius University in Bratislava, Botanical Garden, Detached Unit, SK-038 15 Blatnica 315, Slovakia. E-mail: topercer@rec.uniba.sk.

Ján Kicko, Podtureň 506, SK-033 01 Liptovský Hrádok, Slovakia. E-mail: jano.kicko@gmail.com.

Dušan Karaska, Stodolisko 261, SK-027 41 Oravský Podzámok, Slovakia. E-mail: karaska@vtaky.sk.

Karol Šotnár, Školská 17/12, SK-972 17, Kanianka, Slovakia. E-mail: karol_sotnar@post.sk.

Acknowledgements: Gratitude goes to all of the following collaborators, who contributed to the knowledge of biology and ecology of the lesser spotted eagle in Slovakia. They are: Tomáš Bělka, Ladislav Bohačík, Adriana Burešová, Štefan Cvíčela, Miroslav Demko, Andrej Dubravský, Ivana Fabianová, Marko Fábry, Tomáš Flajs, Erik Gulak, Bedřich Hájek, Ervín Hapl, Stanislav Harvančík, Milan Hlivák, Jirko Hološka, Ján Holmma, Martin Hromada, Ervín Hrtan, Jozef Chavko, Miroslav Chrumka, Jaroslav Jaroš, Pavol Kaňuch, Alojz Kaššák, Dušan Kerestúr, Julián Kňazúr, Ján Korňan, Ján Kurinec, Alexander Kürthy, Miroslav Lehocký, Ján Lipták, Miroslav Madera, Miloš Majda, Bernd-Ulrich Meyburg, Jozef Mihók, Štefan Mikiara, Marian Mojžiš, Aristid Mošanský †, Bohumil Murin, Milan Olekšák, Stanislav Ondruš, Jozef Kohulák, Anton Krištín, Rudolf Kropil, Jozef Palášthy, Štefan Pčola, Vladimír Pečeňák, Peter Pjenčák, Zdeno Pochop, Juraj Popovics, Štefan Porubčanský, Radoslav Potočný, Roman Reištetter, Martin Riník, Slavomír Senk, Pavol Siman, Slávka Siryová, Jozef Sládek, Dominik Sloboda, Oldřich Suchánek, Ladislav Šimák, Ladislav Šnírer, Oldřich Šreibr, Ján Švehlík, Marcel Uhrin, Peter Vrlík, Jozef Voskár, Josef Vrána and Ján Žigraj. Monitoring of the lesser spotted eagle breeding population in the years 2011-2013 was carried out within a framework of the project LIFE09 NAT/SK/000396 "Conservation of Aquila pomarina in Slovakia". The project is implemented by Raptor Protection in Slovakia (RPS) in cooperation with Stredoslovenská energetika, a. s., Stredoslovenská energetika - Distribúcia, a. s. and Východoslovenská energetika Holding, a. s. and cofinanced through the LIFE - Financial Instrument for the Environment of the European Union and the Ministry of the Environment of the Slovak Republic. Our true gratitude goes to Alexander Kürthy for preparation of some maps.

\section{Introduction}

Abundance, distribution and population trend are basic ecological attributes used in studies of bird breeding distribution (Št’astný et al. 1987, Hagemeijer \& Blair 1997, Danko et al. 2002, BirdLife International 2004) and in conservation tools such as red data books and red lists (Hudec 1979, Baruš 1981, Baruš et al. 1988, 1989, Sedláček et al. 1988, Tucker \& Heath 1994, Krištín 1998, Krištín et al. 1998, 2001, Baláž et al. 2001, Jedlička et al. 2007, Demko et al. 2013) or European action plans (Schäffer \& Gallo-Orsi 2001). These attributes are also indispensable in conservation plans for threatened species, for compiling lists of Important Bird Areas (IBAs) (Hora \& Kaňuch 1992, Rybanič et al. 2004), in management plans for Natura 2000 sites and in the assessment of species' conservation status (Polák \& Saxa 2005). Analysing them one can identify threats to individual species populations and design appropriate preventive or corrective measures, if needed. Amendment of national or European legislation or the provision of specialised action plans are other possible outcomes.

Tucker \& Heath (1994) assigned the lesser spotted eagle (Aquila pomarina) to the "SPEC 3" category (SPECs - Species of European Conservation Concern; 
SPEC 3 - Species with an unfavourable European conservation status, but with less than half of the global breeding or wintering population within Europe). According to data on the population decline, the species was reassigned to "SPEC 2" (Species with an unfavourable European conservation status and with more than half of the global breeding or wintering population concentrated in Europe), among declining species whose breeding populations are concentrated in Europe and whose conservation status in Europe is unfavourable (BirdLife International 2004, 2014). The lesser spotted eagle is also included in Annex 1 of the Birds Directive (2009/147/ES).

The aims of this study are (1) to summarise the knowledge on abundance, distribution and trends in the breeding population of the lesser spotted eagle in Slovakia by 1997 and 2014; (2) to compare the breeding population abundance and trends in two periods (by 2000 and 2014), when surveys were conducted using different study designs and (3) to estimate the breeding population size of the lesser spotted eagle in Slovakia by 2014 .

O v e r vi e w of $\mathrm{know}$ le d g e

The breeding range of the species spreads from the Balkan Peninsula, Greece and Turkey in the south up to the Baltic Sea in the north. Its western boundary stretches from north-eastern Germany through Poland, Slovakia, Hungary and Croatia. The eastern boundary of the breeding range in Ukraine and in Russia has not yet been surveyed well (Bergmanis et al. 1997). On the western boundary of the breeding range, even though a gradual decrease in the abundance is stated and the breeding range of this species is shrinking in Germany, in the last decade individual breeding attempts were recorded west of the boundary of this area, namely in France, Czech Republic and Spain. In France, near the border with Switzerland, an attempted breeding was recorded in 2004, and in 2005 a fledging took place in France for the first time (Michelat 2005). Individual birds were also recorded in several other locations (François 2007, Bosch \& Meyburg 2012). In Czech Republic the lesser spotted eagle bred again after 20 years. In 2010 at first two individuals were seen together, in 2011 a pair and in 2012 and 2013 this pair successfully raised a single young bird (Bělka 2014). Most recently an unsuccessful breeding attempt by 1 pair was recorded in 2011 in Catalonia in Spain. In 2012 only one bird of the pair occupied the nest at this site (Bosch \& Mey- burg 2012). The predominant part of the lesser spotted eagle breeding population is concentrated in central, eastern and south-eastern Europe. The abundance of the breeding population is estimated at approximately 20,000 pairs (Meyburg 1996, BirdLife International 2004). Nearly half of the world population breeds in Belarus (approx. 3200-3800 pairs), Latvia (2000-5200 pairs), Romania (2500-2800), Poland (1700-1900), Lithuania (900-1200) and Slovakia (800-900) (BirdLife International 2004). In many European countries, however, the estimate of the abundance of this species is probably strongly underestimated due to their large size and the small number of ornithologists - specialists (e.g. Romania, Turkey, Bulgaria, Russia).

In Slovakia by 2000 , on the basis of assessment for the period from 1980-1999 according to the methodology of mapping the bird distribution in Slovakia, the occurrence of 800-900 breeding pairs of the lesser spotted eagle was assumed (Karaska \& Danko 2002). The abundance of the species breeding population in Slovakia was estimated as early as the 1950s (Sládek 1955) and in eastern Slovakia in the 1970s (Mošanský 1972, Voskár 1976, 1977). For the territory of Czechoslovakia (the entire population bred in Slovakia) the breeding population was estimated in the 1980s and 1990s (Št'astný et al. 1987, Mrlík \& Danko 1989, 1990, Danko 1992b, Murin et al. 1994, Danko et al. 1994). On the basis of mapping the bird distribution in Slovakia (1980-1999), the distribution and abundance of the breeding population of the lesser spotted eagle in Slovakia was also reported (Fig. 1) (Karaska \& Danko 2002) through marking the occupancy of grid squares of the Databank of Slovak Fauna (DFS) (http://dfs.fns.uniba.sk/mapy/komentar.htm, Kroupová 1980, Stloukal 2001, Stloukal \& Grujbárová 2004). The size of a DFS grid square is approximately $12 \times 11 \mathrm{~km}(10$ degrees of longitude $\times 6$ degrees of latitude), that is, an area of about $132 \mathrm{~km}^{2}$ (Danko et al. 2002).

A specialised survey of the species by members of the Group for Research and Protection of Raptors and Owls (SVODAS) contributed to better knowledge of the distribution of the lesser spotted eagle in Slovakia, the results of which were presented in the Report on the activities of SVODAS for the individual years 1975-1992 (Danko 1976, 1977a, b, 1978-1985, 1987-1991, 1992a, 1994a, b), 1993-1995 (Danko et al. 1995a, b, 2000) and in the years 2004-2012 published in the Reports of Raptor Protection of Slovakia (RPS) (Maderič 2005, Dravecký 2006-2013). The publications 


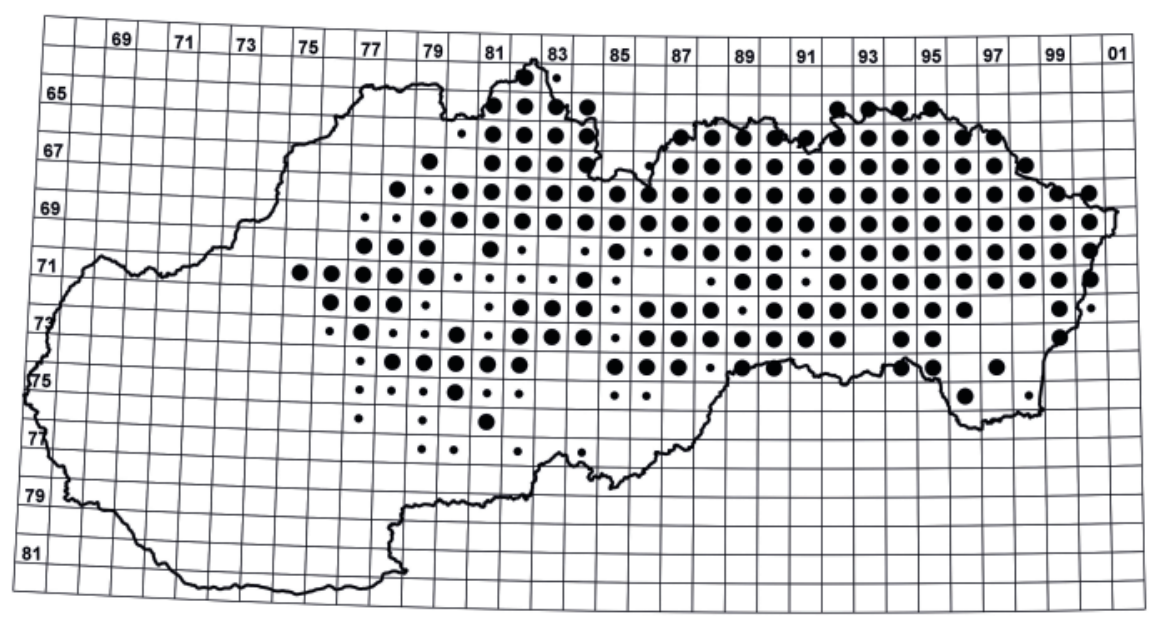

Fig. 1. Distribution of the lesser spotted eagle breeding population in Slovakia by 2000 according to the results of mapping the distribution of birds in Slovakia 1980-1999. Large black point - confirmed breeding, small black point - probable breeding (modified according to Karaska \& Danko 2002).

Obr. 1. Distribúcia hniezdnej populácie orla kriklavého na Slovensku v roku 2000 podla výsledkov mapovania rozšírenia vtákov na Slovensku 1980 - 1999. Vel'ký čierny bod dokázané hniezdenie, malý čierny bod - predpokladané hniezdenie (upravené podl'a Karaska \& Danko 2002). inform about the number of checked breeding sites, the productivity of pairs in the individual years and also express the extent of activities of each member of the specialised working group during research and protection of this species on the territory of the former Czechoslovakia and later in Slovakia. The growth in knowledge on the population of the lesser spotted eagle has led to a continuously increasing estimates of abundance of the breeding population from the 1950s, with a peak during the period around the year 2000 .

\section{Methods}

The abundance and distribution of the lesser spotted eagle breeding population were assessed in two periods: (A) by the year 2000 (period 1980-1999) and (B) by 2014 (period January $1^{\text {st }}, 2011-$ December 31 ${ }^{\text {st }}, 2013$ ). We used a maximum number of unique territories within the spatial and temporal units specified in the individual data sets (Data sets by 2000, and Data sets by 2014, see below). The estimate of the breeding population trend in Slovakia is derived from the comparison of maximum

Tab. 1. Division of mapping units (districts) and map-makers in the questionnaire of the breeding distribution of the lesser spotted eagle in Slovakia by 1997 (evaluated period: 1986-1996).

Tab. 1. Rozdelenie mapovacích jednotiek (okresov) a mapovatel'ov v dotazníkovej akcii hniezdneho rozšírenia orla kriklavého na Slovensku k roku 1997 (hodnotené obdobie rokov 1986-1996).

\begin{tabular}{|c|c|c|c|c|c|}
\hline $\begin{array}{l}\text { no. I } \\
\text { č. }\end{array}$ & $\begin{array}{l}\text { district / } \\
\text { okres }\end{array}$ & $\begin{array}{l}\text { coordinator / } \\
\text { koordinátor }\end{array}$ & $\begin{array}{l}\text { no. / } \\
\text { č. }\end{array}$ & $\begin{array}{l}\text { district / } \\
\text { okres }\end{array}$ & $\begin{array}{l}\text { coordinator / } \\
\text { koordinátor }\end{array}$ \\
\hline 1. & Trebišov & Danko & 19. & Zvolen & Krištín, Kropil \\
\hline 2. & Michalovce & Danko & 20. & Levice & Krištín \\
\hline 3. & Humenné & Maderič, Mikiara & 21. & Žiar n. Hronom & Sloboda, Kurinec \\
\hline 4. & Vranov n. Topl'ou & Kaňuch, Pjenčák & 22. & Prievidza & Šotnár, Chrumka, Cvíčela \\
\hline 5. & Svidník & Maderič & 23. & Martin & Bohačík \\
\hline 6. & Bardejov & Hromada & 24. & Žilina & Porubčanský \\
\hline 7. & Stará L'ubovňa & Bělka, Šrejbr, Vrána & 25. & Čadca & Korňan J. \\
\hline 8. & Prešov & Potočný & 26. & Považská Bystrica & Kaššák \\
\hline 9. & Košice $(m+o)$ & Dravecký, Mihók & 27. & Trenčín & Harvančík \\
\hline 10. & Rožňava & Hapl, Danko, Hlivák, Uhrin, Pochop & 28. & Topol'čany & Harvančík \\
\hline 11. & Spišská Nová Ves & Dravecký, Hájek & 29. & Nitra & Harvančík \\
\hline 12. & Poprad & Danko, Fábry, Jaroš & 30. & Trnava & Chavko \\
\hline 13. & Dolný Kubín & Karaska & 31. & Senica & Chavko, Kürthy, Hološka \\
\hline 14. & Liptovský Mikuláš & Murin, Vrlík, Jaroš & 32. & Bratislava $(m+o)$ & Chavko \\
\hline 15. & Banská Bystrica & Ondruš & 33. & Galanta & Chavko \\
\hline 16. & Rimavská Sobota & Kohulák & 34. & Dunajská Streda & Chavko \\
\hline 17. & Lučenec & Kohulák & 35. & Komárno & Chavko \\
\hline 18. & Vel'ký Krtíš & Krištín & 36. & Nové Zámky & Chavko \\
\hline
\end{tabular}


numbers in two reference periods: (1) by 2000 and (2) by 2014 . For categorisation of the breeding population trend in Slovakia the following scale was used: large decrease $-2(\geq 50 \%)$, small decrease $-1(20-49 \%)$, stable trend $( \pm 19 \%)$, small increase $+1(20-49 \%)$, large increase $+2(\geq 50 \%)$ (Hagemeijer \& Blair 1997, Danko et al. 2002).

$\mathrm{D}$ a t a s e t s b y 2000

- 800-900 pairs - an estimate published by 2000 for the period 1980-1999 (Karaska \& Danko 2002). A total of 271 observers collected data on the occurrence of all bird species in Slovakia (including the lesser spotted eagle) within the period 1980-1999. The results were grid maps of breeding and wintering distribution and abundance of species in the territory of Slovakia (Fig. 1) with accompanying text about each species.

- 762 breeding pairs - a maximum number of unique territories drawn from questionnaires gathered from 56 respondents (Tab. 1) in Slovakia by 1997 (period January $1^{\text {st }}, 1986-$ December $31^{\text {st }}, 1996$ ) and evaluated in this study. The territory of Slovakia was divided into 36 regions (former administrative districts in the years 1990-1996, Fig. 2) and a regional compiler was appointed for each of them. Respondents estimated the breeding population of the lesser spotted eagle by 1997 (period 1986-1996, Appendix 1). Three categories of breeding evidence were distinguished:

a) confirmed breeding pairs - a nest was found at

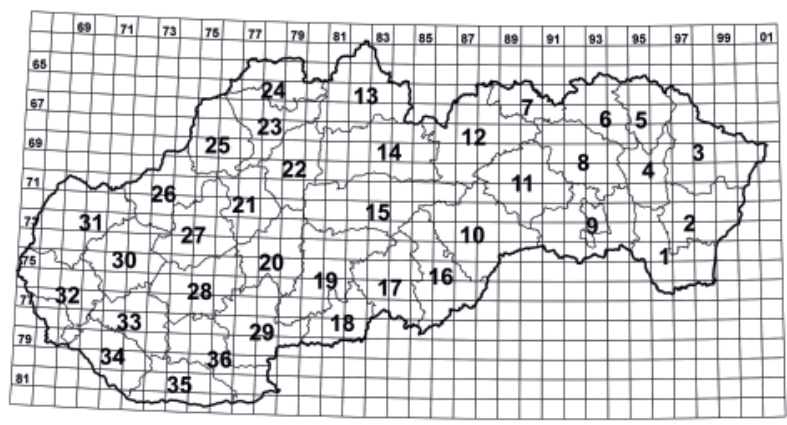

Fig. 2. Mapping units (former districts) for surveying the distribution and abundance of the lesser spotted eagle breeding population in Slovakia by 1997 (evaluated period: 1986-1996).

Obr. 2. Mapovacie jednotky (bývalé okresy) na zist'ovanie distribúcie a početnosti hniezdnej populácie orla kriklavého na Slovensku k roku 1997 (hodnotené obdobie rokov 1986-1996). least once in the reference period, or an adult was recorded entering the forest habitat and carrying food in the breeding season (site positioned by a GPS device and shown on map by a solid black circle);

b) probable breeding pairs - a pair or an individual observed in a suitable nesting habitat once or several times in the reference period (site positioned by a GPS device and shown on map by an empty circle);

c) possible breeding pairs - the numbers were estimated for each region at unvisited sites, where the regional compiler expected their breeding on the basis of habitat suitability and density in the adjacent similar habitats (site not positioned and not shown on the map). As the estimates in this category are, unlike the first two, tied to specific sampling units (districts), we avoided the risk of pseudoreplication by resampling these pairs into the DFS grid squares by 1997 by consulting the original respondents.

- The breeding population sizes given in the National List of Proposed SPAs (ŠOP SR 2014) by 2003 for these SPAs: SKCHVU002 Bukovské vrchy Mts, SKCHVU008 Horná Orava, SKCHVU011 Laborecká vrchovina Upland, SKCHVU018 Nízke Tatry Mts, SKCHVU025 Slanské vrchy Mts, SKCHVU027 Slovenský kras Mts, SKCHVU030 Tatry Mts, SKCHVU035 Vihorlatské vrchy Mts, SKCHVU036 Volovské vrchy Mts (in these SPAs the lesser spotted eagle meets the criterion K1, i. e. the individual SPAs hosts more than $1 \%$ of the national population) and SKCHVU053 Slovenský raj Mts.

- Selected well-monitored model regions over the long term by 2000: 1) The orographic unit (OrU) Vihorlatské vrchy Mts and adjacent area 1970-1999, 2) OrU Laborecká vrchovina Upland and adjacent area 1985-1999, 3) OrU Volovské vrchy Mts and adjacent area 1990-1999, 4) Orava Region 1982-1999 and 5) Horné Ponitrie Region 1990-1999. Boundaries and names of orographic units are according to Mazúr \& Lukniš (1980).

\section{$\mathrm{D}$ a t a s e t s b y 2014}

- An estimate of the breeding population size in Slovakia by 2014 using extrapolation from a sample of c. 160 breeding pairs obtained as an outcome of the project LIFE 09NAT/SK/000396 "Conservation of 
Aquila pomarina in Slovakia" (hereinafter only the "LIFE project") in the period January $1^{\text {st }}$, 2011-December 31 st 2013 , within the eight project SPAs: SKCHVU008 Horná Orava, SKCHVU011 Laborecká vrchovina Upland, SKCHVU018 Nízke Tatry Mts, SKCHVU025 Slanské vrchy Mts, SKCHVU027 Slovenský kras Mts, SKCHVU030 Tatry Mts, SKCHVU035 Vihorlatské vrchy Mts and SKCHVU036 Volovské vrchy Mts.

- Updated numbers of breeding pairs by 2014 from the results of the LIFE project and surveys of the working group for the lesser spotted eagle within the RPS from SKCHVU002 Bukovské vrchy Mts, SKCHVU008 Horná Orava, SKCHVU011 Laborecká vrchovina Upland, SKCHVU018 Nízke Tatry Mts, SKCHVU025 Slanské vrchy Mts, SKCHVU027 Slovenský kras Mts, SKCHVU030 Tatry Mts, SKCHVU035 Vihorlatské vrchy Mts, SKCHVU036 Volovské vrchy Mts and SKCHVU053 Slovenský raj Mts in the period January $1^{\text {st }}, 2011-$ December $31^{\text {st }}, 2013$.

- The numbers of breeding pairs in DFS grid squares within the boundaries of the present SPAs: by comparison of the questionnaire results by 1997 with the results of the LIFE project in the period January $1^{\text {st }}$, 2011-December 31 2013.

- The breeding population size in selected well-monitored model regions in the period January $1^{\text {st }}$, 2011-December 31 st 2013: a) OrU Vihorlatské vrchy Mts and the adjacent area, b) OrU Laborecká vrchovina Upland and the adjacent area, c) OrU Volovské vrchy Mts and the adjacent area, d) Orava Region and 5) Horné Ponitrie Region.

D a t a exploration and processing prior to analysis inc 1 u d e d:

- Correcting obvious errors and fixing discrepancies between the raw data sets from the individual SPAs and from the questionnaire vs the LIFE project so as to achieve their consistency and comparability.

- Removing the effects of changes in SPA boundaries (the national list of proposed SPAs vs declared SPAs) from each data set.

- Representing each data set (SPAs and remaining areas) spatially using the Geographical Information System (GIS) ESRI ArcMap 9.1.

- Rrepresenting the distribution and numbers of breeding pairs in the DFS grid squares for each SPA and remaining areas (including the resampling of the possible breeding pair numbers by 1997).

- Representing both data sets as states of the breeding population by 2000 (reference) and 2014 .

The model region approach seemed to be the most appropriate methodological framework for the analysis. As model regions we choose those of the declared SPAs that (1) were sampled most completely and accurately in both periods; (2) show the least interobserver variability both within and between periods (ideally, the same observer); (3) after removing the effects of changes in SPA boundaries have a sample size of at least 8 confirmed breeding pairs and (4) as a whole set provide sufficiently representative coverage of the Slovakian/western Carpathian part of the species' breeding range.

A total of eight SPAs meet these requirements: Horná Orava, Slanské vrchy Mts, Laborecká vrchovina Upland, Volovské vrchy Mts, Tatry Mts, Vihorlatské vrchy Mts, Nízke Tatry Mts and the Slovenský kras Mts. In subsequent analyses we treated the distribution, breeding pair numbers or densities and population trends in these SPAs as (1) a set of eight sites $(n=8)$ and (2) a set of eight sites, divided by the DFS grid into 119 squares $(n=119)$.

Using the procedures of data screening (to check the completeness, accuracy and reliability of the data, detect missing values, outliers, collinearity, dependence of observations, problems with interactions, double zeros and zero inflation) including the tests of normality of distributions and homogeneity of variances we found that (1) in the first approach $(n=8)$ c. $40 \%$ of the data violate the assumptions of normality, homogeneity of variances and linearity of relationships (but not too significantly, as the small sample suggests), while in the second approach $(\mathrm{n}=119)$ all data did so at a high significance level $(\alpha<0.001)$; (2) missing values and outliers were not present in the first approach and zeros in only c. $19 \%$ of cases, while in the second approach the data set was more than $49 \%$ zero-inflated and c. $10 \%$ of it were outliers.

Such different data sets also required different analyses. In the first approach we employed mostly summary statistics and both parametric (t-test and Aspin-Welch test) and non-parametric (Mann-Whitney and Kolmogorov-Smirnov) two-sample tests so as to obtain interval estimates of the mean values (median, unweighted and weighted arithmetic mean $\pm 95 \%$ confidence interval) and their variability (interquartile range, unbiased standard deviation) for linear extrapol- 
ation of the breeding pair numbers, densities and trends to the entire breeding range in the Slovak Republic.

The second approach involved (1) testing the significance of differences by 1997 and 2014 using twosample tests; (2) testing the significance of differences in the breeding pair numbers and densities between the eight selected SPAs using one-way Kruskal-Wallis analysis of variance (ANOVA) with correction of ties and post-hoc Kruskal-Wallis multiple comparison z-value test taking Bonferroni corrections for all pairs; (3) subsequent descriptive classification of the structure of relationships among the eight selected SPAs using cluster analysis, particularly the hierarchical agglomerative algorithm (technique of unweighted pair group means, UPG) and a divisive fuzzy algorithm for the purpose of stratification and extrapolation of the numbers, densities and trends and (4) analysis of relationships between the numbers of all breeding pairs and factors such as year (by 1997 and 2014), site (8 SPAs) and observer (1 identical, 2 - different between periods) using Poisson loglinear regression, general linear models (GLM) and loglinear models, for which the numbers of pairs in each DFS grid square were grouped into five categories: 0, 1 (1-2 pairs), 2 (3-5 pairs), 3 (6-9 pairs) and 4 (10 or more pairs).

We performed all analyses employing the statistical system NCSS 2001 (Hintze 1997-2001). The areas of individual SPAs were calculated from the current GIS layers of the declared SPAs (provided by State Nature Conservancy of Slovak Republic) in the ESRI ArcMap 9.3 environment (Calculate Geometry module).

The monitoring in the SPA Slanské vrchy Mts in the period January $1^{\text {st }}, 2011-D e c e m b e r ~ 31^{\text {st }}, 2013$, took place only in the southern part of the SPA, falling into DFS grid squares 7294, 7295, 7394, 7395, 7494 and 7495 . The corresponding area of the monitored territory totalled $284 \mathrm{~km}^{2}$ and the density of the pairs for this section of the SPA (Slanské vrchy Mts - south) was calculated from this. To estimate the trend and to test the significance of differences, we therefore selected only data for the six DFS grid squares from the 1997 questionnaire, as well as from the monitoring in 2011-2013. Two pairs in the SPA Slanské vrchy Mts found outside the divided territory were thus not included in the analysis.

In the scope of the LIFE project in 2011-2013 several pairs of eagles were monitored which bred directly on the boundary of an SPA or had several nests, some of which were located within an SPA and some outside an
SPA. We included in the statistical analysis only those pairs of eagles by 2014 whose nest was located within an SPA. We also excluded pairs which bred several tens of metres beyond the boundary of an SPA. As we mentioned above, in the study we do not analyse those SPAs in which the number of pairs of lesser spotted eagles in the national list of SPAs were either $\mathrm{n}<8$ pairs $(<1 \%$ of the national population of the species in Slovakia, i. e. from $800-900$ pairs by year 2000 - Karaska \& Danko 2002) [SKCHVU017 Muránska planina Plateau and Stolické vrchy Mts (7), SKCHVU022 Pol'ana (6), SKCHVU050 Chočské vrchy Mts (4), SKCHVU013 Malá Fatra Mts (3), SKCHVU015 Medzibodrožie (2), SKCHVU028 Strážovské vrchy Mts (2)], or also $\mathrm{n} \geq 8$ pairs, if for comparison current data by 2014 was missing, such as in SKCHVU051 Levočské vrchy Mts (15) and SKCHVU052 Čergov Mts (21). However, we did use data from the first mentioned group of SPAs for verifying the validity of the estimates.

\section{Results and discussion}

The abundance and density of the lesser spotted eagle breeding population in Slovakia is not the same (Fig. 3) but changes according to the conditions of the environment and their suitability for this species. The lesser spotted eagle inhabits areas with deciduous, coniferous and mixed forests from the Východoslovenská nížina

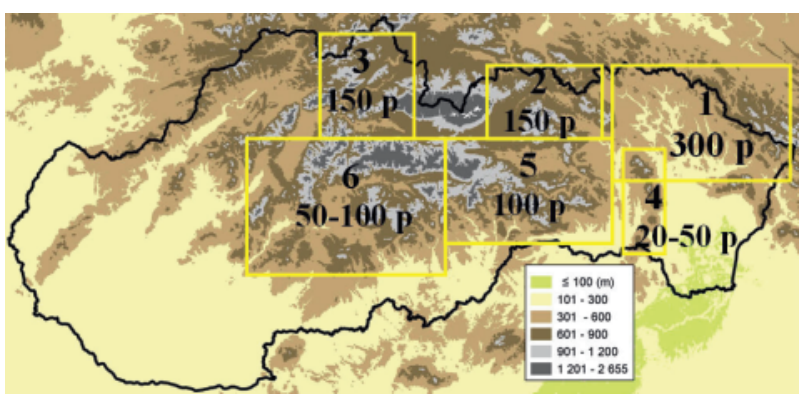

Fig. 3. Schematic illustration of the abundance and density of the lesser spotted eagle population according to hypsographical division of Slovakia (in m a.s.I.) 1 - 300 pairs, 4.8-5.0 p.100 km-2; 2 - 150 pairs, 6.4 p. $100 \mathrm{~km}^{-2}$; 3 - 150 pairs, 6.25-9.7 p.100 km-2; $4-20-50$ pairs; 5 - 100 pairs, $0.26-2.0$ p.100 km-2; $6-50-100$ pairs (modified according to Dravecký et al. 2006).

Obr. 3. Schematické znázornenie početnosti a hustoty hniezdnej populácie orla kriklavého podla hypsografického členenia Slovenska (v m n. m.) 1 - 300 párov, 4,8-5,0 p.100 km²; 2 150 párov, 6,4 p.100 km-2; 3 - 150 párov, 6,25-9,7 p.100 km-2; 4 - 20-50 párov; 5 - 100 párov, 0,26-2,0 p.100 km-2; 6 50-100 párov (upravené podl'a Dravecký et al. 2006). 
Lowland and the Podunajská nížina Lowland (approx. $100 \mathrm{~m}$ a.s.1.), through the hills and uplands up through mountain forests at elevations from $900-1100 \mathrm{~m}$. The highest abundance of the breeding population was recorded in the north of eastern Slovakia (Ondavská vrchovina Upland, Laborecká vrchovina Upland, Bukovské vrchy Mts, Beskydské predhorie Foothills, Slanské vrchy Mts, Spišsko-šarišské medzihorie Mts and the Črgov Mts) in a total of approximately 500 breeding pairs. Locally, however, we also record high breeding density in other regions, e.g. in the Žiarska kotlina Basin up to more than 10 pairs. $100 \mathrm{~km}^{-2}$ (Kicko 2006a, b). Maderič et al. (1995) gives 4.8 pairs. $100 \mathrm{~km}^{-2}$ for the western part of the Humenné district $\left(929 \mathrm{~km}^{2}\right)$, Pčola (in Karaska \& Danko 2002) 5 pairs. $100 \mathrm{~km}^{-2}$ for the Snina district, and Potočný (1991) gives 2 pairs. $100 \mathrm{~km}^{-2}$ for the Prešov district $\left(1414 \mathrm{~km}^{2}\right)$. In the region of the Spišská Magura Mts, the Lubovnianska vrchovina Upland, the Spišsko-šarišské medzihorie Mts and the Levočské vrchy Mts a density of 6.4 pairs. $100 \mathrm{~km}^{-2}$ was recorded (Dravecký et al. 2006). A similarly high abundance was also found in northern central Slovakia (Podbeskydská brázda Furrow, Podbeskydská vrchovina Upland, Oravská vrchovina Upland, Oravská kotlina Basin, Skorušinské vrchy Mts, Podtatranská brázda Furrow, Liptovská kotlina Basin with the adjacent slopes of the Západné and Nízke Tatry Mts), where approximately 150 pairs bred. In the Orava Region for the former district of Dolný Kubín $\left(1661 \mathrm{~km}^{2}\right)$ 100-120 pairs and a density of 6.25 pairs. $100 \mathrm{~km}^{-2}$ is given (Karaska in Danko et al. 1994). In the area of the Volovské vrchy Mts, Košická kotlina Basin, Rožňavská kotlina Basin, Slovenský kras Mts, Čierna hora Mts, Slovenský raj Mts, Hornádska kotlina Basin and Branisko Mts the breeding population is estimated at 100 pairs (Dravecký et al. 2006). Dravecký (2000) gives for the Volovské vrchy Mts - central part $\left(375 \mathrm{~km}^{2}\right)$ a density of only 0.26 pairs. $100 \mathrm{~km}^{-2}$ and from the territory of the Slovensky kras Mts and the Volovské vrchy Mts $\left(1900 \mathrm{~km}^{2}\right) 1.47$ pairs. $100 \mathrm{~km}^{-2}$ (Dravecký 2004a). In the areas of the Kremnické vrchy Mts, Zvolenská kotlina Basin, Pol'ana Mts, Vtáčnik Mts, Žiarska kotlina Basin, Štiavnické vrchy Mts, Pliešovská kotlina Basin, Javorie Mts, Hornonitrianska kotlina Basin, Žiarska and Turčianska kotlina Basins approx. 80-120 breeding pairs were estimated (Kicko 2006a, b, Šotnár 2006, Bohačík 1976, 1988).

In Slovakia the majority of the lesser spotted eagle breeding population occurs in habitats at an elevation of
$300-700 \mathrm{~m}$ with a mosaic of forested units, meadows, pastures, fields, flooded areas and a network of watercourses (Laborecká vrchovina Upland, Ondavská vrchovina Upland). The more moderately modelled flysch mountains of northern and eastern Slovakia are especially densely inhabited. The lesser spotted eagle breeds in coniferous, deciduous and mixed forests, often at the interface of large forested complexes at elevations of 500-800 m and connected to an open landscape (Vihorlatské vrchy Mts, Slanské vrchy Mts). In submontane and mountain basins it breeds at the interface of mountain forests (Slovenské Rudohorie Mts, Nízke Tatry Mts, Západné Tatry Mts, Oravské Beskydy Mts, Oravská Magura Mts, Vtáčnik Mts) and basins of non-forest formations of meadows, pastures and fields in the Hornádska, Popradská, Oravská, Liptovská, Hornonitrianska, Zvolenská and Žiarska kotlina Basins. It avoids extensive forest complexes and forests above $1000 \mathrm{~m}$ a.s.l. (Dravecký 2000). The breeding of 1 pair was rarely recorded in the Nízke Tatry Mts at an elevation of $960 \mathrm{~m}$ a.s.l. (Kicko \& Vrlík in prep.). It breeds only exceptionally in lowland areas. Danko found an occupied nest in a lowland forest on the Východoslovenská nížina Lowland (Karaska \& Danko 2002). Among the highest documented findings were nests in the Nízke Tatry Mts at elevations of 880, 950 and $960 \mathrm{~m}$ (Kicko \& Vrlík in prep.) and in the Slovenský raj Mts at an elevation of $870 \mathrm{~m}$ (Dravecký 2004b).

Results of abundance estimates of the lesser spotted

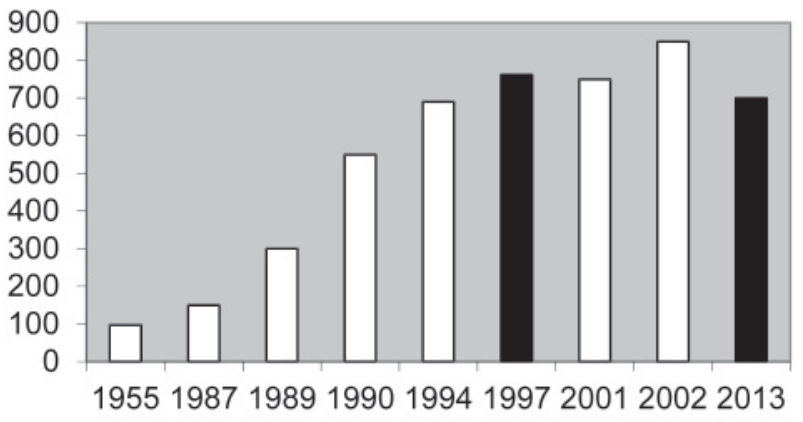

Fig. 4. Development of abundance estimates of the lesser spotted eagle breeding population in 1950-2013. Data from 1997 and 2013 are the results of this study. White column - published data, black column - results of this study.

Obr. 4. Vývoj odhadov početnosti hniezdnej populácie orla kriklavého v rokoch 1950-2013. Údaje za roky 1997 a 2013 sú výsledkami tejto štúdie. Biele stípce - publikované údaje, čierne stípce - výsledky tejto štúdie. 
eagle breeding population in Slovakia from the 1950s were published as follows: in 1955: 75-120 pairs (Sládek 1955, Mošanský 1972, Voskár 1976, 1977), 1987: 150 pairs (Št’astný et al. 1987), 1989: 300 pairs (Mrlík \& Danko 1989, 1990), 1990: 500 or 500-600 pairs (Danko 1992b, Murin et al.1994, Danko et al. 1994), 1994: "up to 700 pairs" (Karaska in Danko et al. 1994), 2001: "more than 700 pairs" (Meyburg et al. 2001), with the highest estimate of abundance in the period from 2000: 800-900 pairs (Karaska \& Danko 2002). This development of abundance estimates is supplemented by the results of this study by 1997 , with an estimate of 762 pairs, and by 2014, with an estimate of 600-800 pairs (Fig. 4). The estimate by 1997 falls into an increasing trend of development of published abundance estimates of the species' breeding population in Slovakia from 1955-2002. The estimate by 2014 is already showing a smaller number of breeding pairs in comparison with the estimate by year 2000 and for the first time in history a declining trend is being recorded.

De termination of a b und a n c e of the breeding population b y 1997

By 1997 the total estimate of the lesser spotted eagle breeding population included 762 pairs in 36 districts (mapping units) in which were then the three administrative regions of Eastern, Central and Western Slovakia (Appendix 1). The total estimate was made up of three categories of conclusive breeding: 353 confirmed pairs (CP), 276 probable pairs (PP) and 133 possible pairs (PoP). Within Slovakia the largest portion of the population bred in eastern Slovakia - 505 pairs with a density of 3.1 pairs. $100 \mathrm{~km}^{-2}$, in central Slovakia with 252 pairs (1.4 pairs. $100 \mathrm{~km}^{-2}$ ) and in western Slovakia only 5 pairs $\left(0.03\right.$ pairs. $\left.100 \mathrm{~km}^{-2}\right)$. The density of pairs in the individual mapping units (districts) achieved a range of 0.1-8 pairs. $100 \mathrm{~km}^{-2}$ (calculated from all tree categories: CP, PP, PoP). In eastern Slovakia five districts were found with a density higher than 4 pairs. $100 \mathrm{~km}^{-2}$ Vranov nad Topl'ou (4.3), Bardejov (4.4), Svidník (5.2), Humenné (5.3) and Stará L'ubovňa (8). Four of these five districts are located in north-eastern Slovakia in the OrU Laborecká and Ondavská vrchovina Uplands. The highest density of pairs in the eastern part and in all of Slovakia was found in the Stará Lubovňa district (8 pairs. $100 \mathrm{~km}^{-2}$ ) in north-eastern Slovakia near the border with Poland in the OrU Levočské vrchy Mts, Lubovnianska vrchovina Upland, Popradská kotlina
Basin, Spišská Magura Mts and Spišsko-šarišské medzihorie Mts. In central Slovakia a density higher than 4 pairs. $100 \mathrm{~km}^{-2}$ was found only in the Dolný Kubín district, with a density of 7 pairs. $100 \mathrm{~km}^{-2}$. In western Slovakia not even one district exceeded a density of 0.2 pair. $100 \mathrm{~km}^{-2}$ (Appendix 1, Fig. 5). The distribution of breeding pairs in the individual districts of Slovakia by 1997 and their densities is supplemented by processing the distribution of the two most demonstrable categories of breeding occurrence, namely confirmed (CP) and probable pairs (PP), expressed by the sum of $\mathrm{CP}$ and $\mathrm{PP}$ for each DFS grid square (Fig. 6; the darker the shadow, the higher the number of pairs in the relevant DFS grid square). The highest numbers of pairs in the DFS grid squares were recorded in the Dolný Kubín district in the range of 9-15 pairs and in Stará Lubovña in the range of 9-11 pairs. In north-eastern Slovakia are several DFS grid squares with 8-10 pairs, but squares with values of 4-8 pairs have a larger area representation. A relatively larger number of DFS grid squares with a count of 1 pair are mainly found in central Slovakia. Pairs of the $3^{\text {rd }}$ category, with the lowest conclusiveness of breeding (possible pairs, PoP), are not included in this evaluation due to their numbers being determined only by expert estimate but without information on the exact or at least geographical positions of breeding sites of the individual pairs.

The breeding of the lesser spotted eagle in Slovakia by 1997 was recorded at elevations of 100-1100 m (Fig. 7). From the two commonly evaluated categories of confirmed and probable pairs, by 1997 only 1 pair $(0.16 \%)$ was recorded at an elevation from $0-100 \mathrm{~m}, 7$ pairs $(1.13 \%)$ from $101-200 \mathrm{~m}$ and 44 pairs $(7.13 \%)$ from $201-300 \mathrm{~m}$. A decreasing tendency in the number of pairs is visible at elevations above $900 \mathrm{~m}$, namely with 23 pairs $(3.73 \%)$ from $901-1000 \mathrm{~m}, 6$ pairs $(0.97 \%)$ at $1001-1100$ and no pairs found at $1101-1200 \mathrm{~m}$. The highest number of pairs (112 pairs, $18.16 \%$ ) was recorded at elevations of 601-700 m. We see a nearly uniform distribution of pairs at elevations of 301-900 m, namely $80-100$ pairs (13-15\%) for each $100 \mathrm{~m}$ (Tab. 2, Fig. 8). With intervals of elevation levels of $300 \mathrm{~m}$ the population of the lesser spotted eagle by 1997 was distributed as follows: 52 pairs $(8.43 \%)$ from $0-300 \mathrm{~m}, 269$ pairs $(43.6 \%)$ from $301-600 \mathrm{~m}, 267$ pairs (43.27\%) from $601-900 \mathrm{~m}$ and 29 pairs (4.7\%) from 901-1200 m (Tab. 2, Fig. 9). From the mentioned it follows that the elevation distribution of the breeding population of the lesser spotted eagle in 

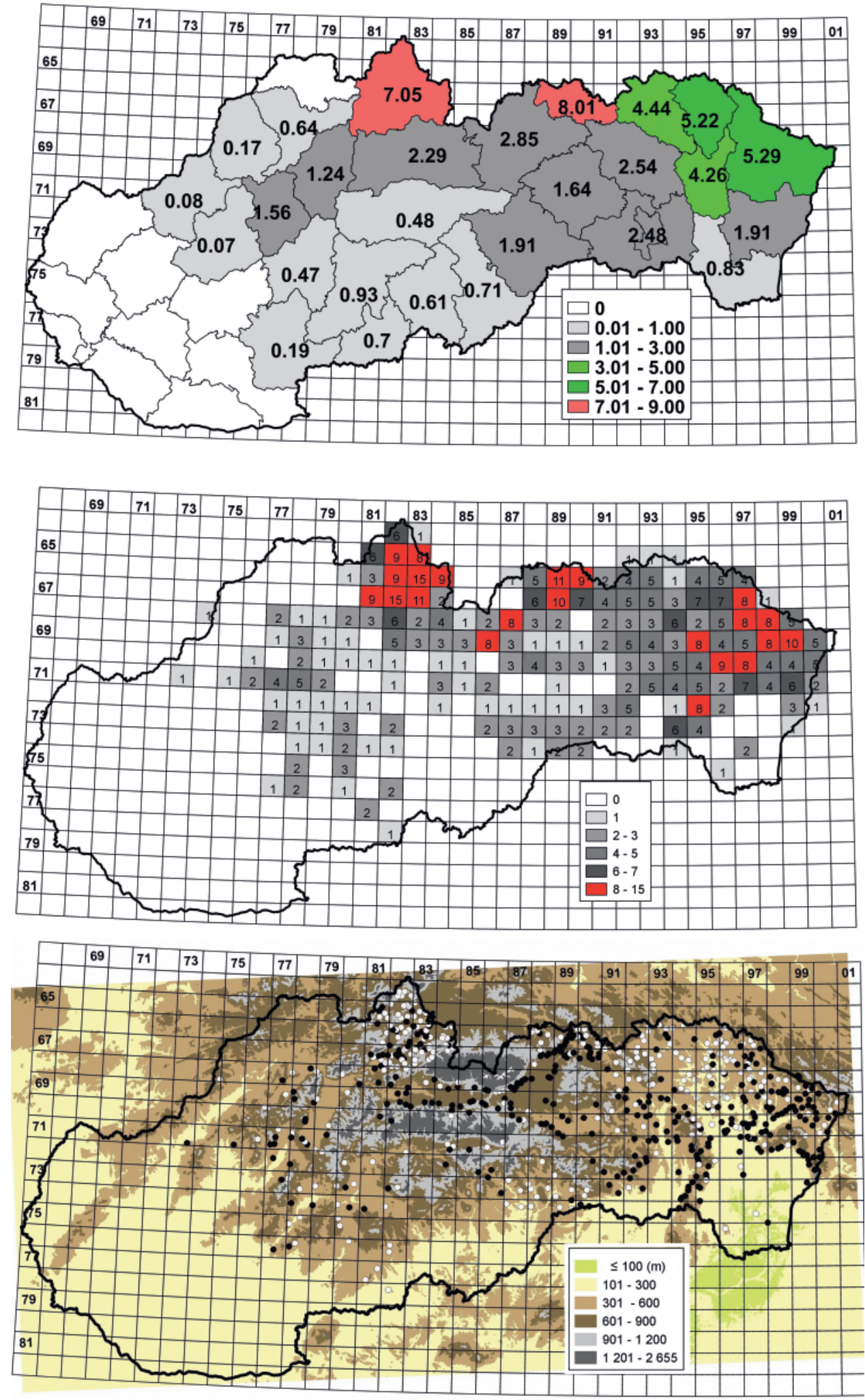

Fig. 5. Density of the lesser spotted eagle breeding population in the mapping units (districts) in Slovakia by 1997 (in pairs. $100 \mathrm{~km}^{-2}$ ).

Obr. 5. Hustota hniezdnej populácie orla krikl'avého $\mathrm{v}$ mapovacích jednotkách (okresoch) na Slovensku k roku 1997 (v pároch. $100 \mathrm{~km}^{-2}$ ).

Fig. 6. Abundance of confirmed and probable breeding pairs (together) of the lesser spotted eagle in the DFS grid squares by 1997 .

Obr. 6. Početnost' zistených a predpokladaných hniezdnych párov (spolu) orla kriklavého $v$ sieti kvadrátov DFS k roku 1997.

Fig. 7. Distribution of the lesser spotted eagle breeding population in Slovakia according to hypsographical division of Slovakia with localisation of confirmed and probable breeding pairs by 1997 according to this study. Black circle - confirmed pairs, white circle - probable pairs. Hypsographical scale - elevation in $m$ a.s.l.

Obr. 7. Distribúcia hniezdnej populácie orla kriklavého na Slovensku podla hypsografického členenia Slovenska s lokalizáciou zistených a predpokladaných hniezdnych párov k roku 1997 podl'a tejto štúdie. Čierny krúžok - zistené páry, biely krúžok - predpokladané páry. Hypsografická škála nadmorská výška v m n. m. 

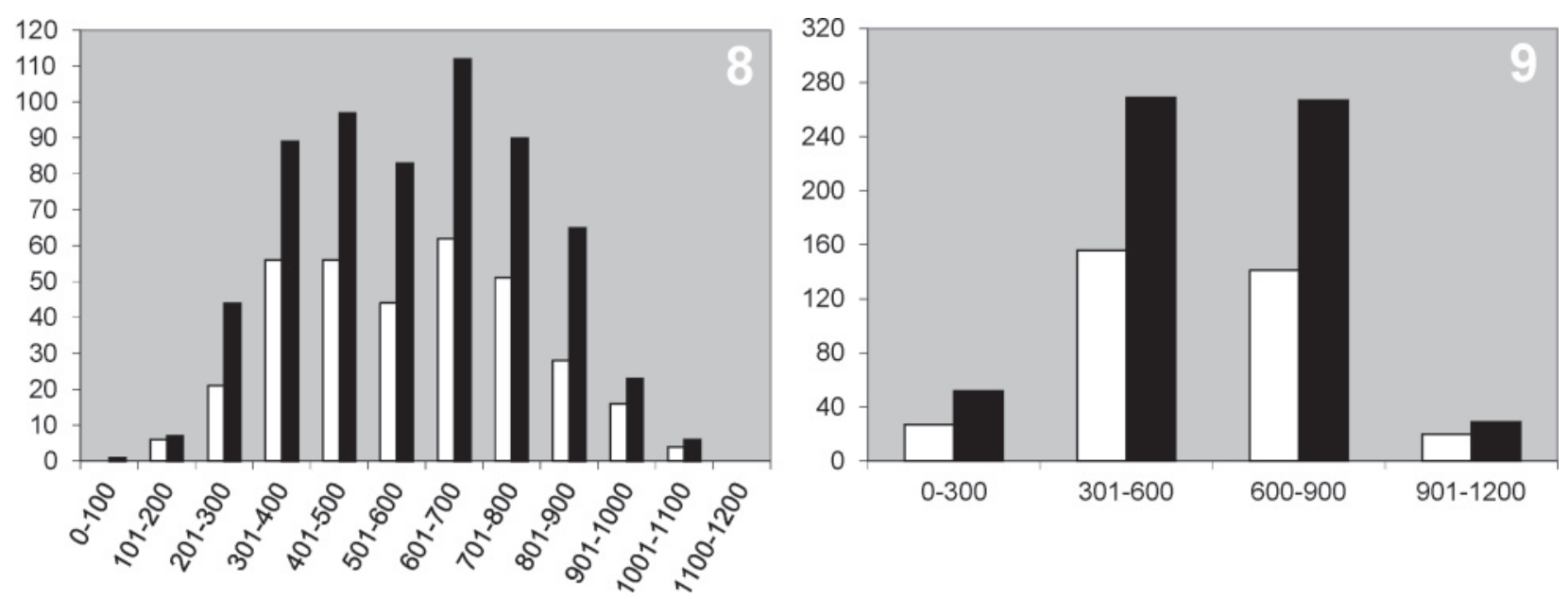

Figs 8-9. Hypsographical division of confirmed and probable breeding pairs of the lesser spotted eagle in $100 \mathrm{~m}$ elevation intervals in Slovakia by 1997 (8). Hypsographical division of confirmed and probable breeding pairs of the lesser spotted eagle in $300 \mathrm{~m}$ elevation intervals in Slovakia by 1997 (9). White columns - confirmed pairs, black columns -confirmed and probable pairs together. Obr. 8-9. Hypsografické rozdelenie zistených a predpokladaných hniezdnych párov orla kriklavého v $100 \mathrm{~m}$ výškových intervaloch na Slovensku k roku 1997 (8). Hypsografické rozdelenie zistených a predpokladaných hniezdnych párov orla kriklavého v $300 \mathrm{~m}$ výškových intervaloch na Slovensku k roku 1997 (9). Biele stípce - zistené páry, čierne stípce - zistené a predpokladané páry spolu.

\begin{tabular}{|c|c|c|c|c|c|c|}
\hline \multirow{2}{*}{$\begin{array}{l}\text { altitude above } \\
\text { sea level / } \\
\text { nadmorská } \\
\text { výška } \\
\mathrm{m} \\
\end{array}$} & \multicolumn{2}{|c|}{$\begin{array}{l}\text { confirmed } \\
\text { pairs / } \\
\text { zistené } \\
\text { páry }\end{array}$} & \multicolumn{2}{|c|}{$\begin{array}{l}\text { probable } \\
\text { pairs / } \\
\text { predpokladané } \\
\text { páry }\end{array}$} & \multicolumn{2}{|l|}{$\Sigma$} \\
\hline & $(\mathrm{CP})$ & $\%$ & (PP) & $\%$ & (CP \& PP) & $\%$ \\
\hline $0-100$ & 0 & 0.00 & 1 & 0.37 & 1 & 0.16 \\
\hline $101-200$ & 6 & 1.74 & 1 & 0.37 & 7 & 1.13 \\
\hline $201-300$ & 21 & 6.10 & 23 & 8.42 & 44 & 7.13 \\
\hline $301-400$ & 56 & 16.28 & 33 & 12.09 & 89 & 14.42 \\
\hline $401-500$ & 56 & 16.28 & 41 & 15.02 & 97 & 15.72 \\
\hline $501-600$ & 44 & 12.80 & 39 & 14.29 & 83 & 13.45 \\
\hline $601-700$ & 62 & 18.00 & 50 & 18.32 & 112 & 18.16 \\
\hline $701-800$ & 51 & 14.83 & 39 & 14.29 & 90 & 14.59 \\
\hline $801-900$ & 28 & 8.14 & 37 & 13.55 & 65 & 10.53 \\
\hline $901-1000$ & 16 & 4.65 & 7 & 2.56 & 23 & 3.73 \\
\hline $1001-1100$ & 4 & 1.16 & 2 & 0.73 & 6 & 0.97 \\
\hline $1100-1200$ & 0 & 0.00 & 0 & 0.00 & 0 & 0.00 \\
\hline $0-300$ & 27 & 7.85 & 25 & 9.16 & 52 & 8.43 \\
\hline $301-600$ & 156 & 45.35 & 113 & 41.39 & 269 & 43.60 \\
\hline $601-900$ & 141 & 40.99 & 126 & 46.15 & 267 & 43.27 \\
\hline $901-1200$ & 20 & 5.81 & 9 & 3.30 & 29 & 4.70 \\
\hline$\Sigma$ & 344 & 100.00 & 273 & 100.00 & 617 & 100.00 \\
\hline
\end{tabular}

Tab. 2. Division of confirmed (CP) and probable (PP) breeding pairs of the lesser spotted eagle in Slovakia by 1997 according to elevation in $100 \mathrm{~m}$ and $300 \mathrm{~m}$ elevation intervals, respectively.

Tab. 2. Rozdelenie zistených (CP) a predpokladaných (PP) hniezdnych párov orla kriklavého na Slovensku k roku 1997 podla nadmorskej výšky v 100 m a 300 m výškových intervaloch.
Slovakia is concentrated at two elevation levels (301-600 $\mathrm{m}$ and 601-900 m), at which they are nearly identical. The smallest numbers of breeding pairs were recorded at elevations from 0-300 m and 901-1200 m.

The lowest breeding ground lay at an elevation of about $100 \mathrm{~m}$, in the Trebišov district in the
Východoslovenská nížina Lowland, and the highest breeding ground was situated again in the Nízke Tatry Mts. A dominant portion of the Slovak population was located in north-eastern Slovakia in the Laborecká and Ondavská vrchovina Uplands, with an elevation range of 200-600 $\mathrm{m}$ a.s.1. A high local abundance, 


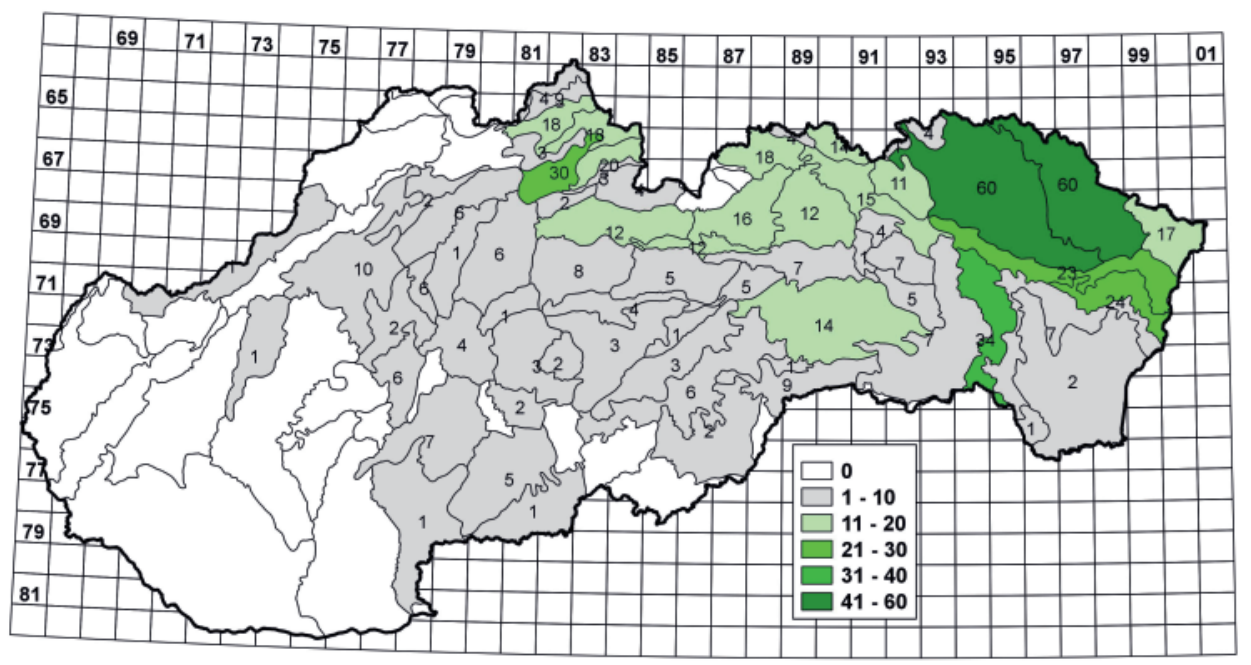

Fig. 10. Spatial distribution and overall numbers of confirmed and probable breeding pairs of the lesser spotted eagle in orographic units of Slovakia by 1997.

Obr. 10. Priestorová distribúcia a celkové počty zistených a predpokladaných hniezdnych párov orla kriklavého $v$ orografických celkoch Slovenska k roku 1997.

however, was found in the Lubovnianska vrchovina Upland at elevations of 300-900 m a.s.l. and in Horná Orava at 600-900 $\mathrm{m}$ a.s.l. We located the highest breeding pairs in the Tatra Mts and Nízke Tatry Mts at elevations of 600-1100 m. Hunting grounds of lesser spotted eagles in Slovakia are predominately at elevations of 200-700 m. In exceptional cases they climb up to bare open spaces and clear-cut sites at elevations of 900-1000 m in the Nízke Tatry Mts, Oravské Beskydy Mts, Oravská Magura Mts and Skorušinské vrchy Mts. Flyovers of eagles from breeding grounds to hunting grounds and back were also recorded at elevations of 1000-1500 m.

Within the whole of Slovakia breeding grounds were located in a range from 100-1100 $\mathrm{m}$ a.s.l. In eastern Slovakia they lay in a range from 100-900 m a.s.l., in central Slovakia from 200-1100 m a.s.l. and in western Slovakia from $200-600 \mathrm{~m}$ a.s.l. The nests found in Slovakia were located in a range from $100-960 \mathrm{~m}$ a.s.l., from 100-900 $\mathrm{m}$ a.s.l. in eastern Slovakia, from 300-960 m a.s.l. in central Slovakia and from 400-500 m a.s.1. in western Slovakia (Appendix 2). In comparison, e.g. with the Baltic states (Lithuania, Latvia, Estonia), breeding and hunting grounds in Slovakia are at significantly higher elevations, but in comparison, e.g. with Romania, Ukraine and Poland, the location of breeding pairs in the Carpathian Mountains is approximately the same.

Tab. 3. Abundance and density of the lesser spotted eagle breeding population in selected SPAs in Slovakia in 2013. Source: $\left.{ }^{*}\right)$ Regulations of Ministry of Environment of SR, ${ }^{* *}$ ) GIS layers of SPAs - State Nature Conservancy of SR. The latter data on areas of individual SPAs are used for analyses in the paper. Calculated population density is the same for the both sources of SPAs' area. Tab. 3. Početnost' a hustota hniezdnej populácie orla kriklavého vo vybraných CHVú Slovenska v roku 2013. Zdroj: *) Vyhlášky MŽP $\left.S R,{ }^{* *}\right)$ GIS vrstvy CHVÚ - ŠOP SR. Posledne menované dáta boli používané v analýzach. Vypočitaná hustota populácie je rovnaká pre oba zdroje rozlôh CHVÚ.

\begin{tabular}{|c|c|c|c|c|c|c|c|}
\hline $\begin{array}{l}\text { SPA / } \\
\text { CHVÚ }\end{array}$ & $\begin{array}{l}\text { confirmed } \\
\text { pairs / } \\
\text { zistené } \\
\text { páry }\end{array}$ & $\begin{array}{l}\text { probable } \\
\text { pairs / } \\
\text { predpokl. } \\
\text { páry }\end{array}$ & $\begin{array}{l}\text { possible } \\
\text { pairs / } \\
\text { odhad. } \\
\text { páry }\end{array}$ & $\Sigma$ & $\begin{array}{l}\text { area } \\
\text { of SPA* / } \\
\text { rozloha } \\
\text { CHVú* }\end{array}$ & $\begin{array}{l}\text { area } \\
\text { of SPA }{ }^{* \star} / \\
\text { rozloha } \\
\text { CHVÚ }^{\star *}\end{array}$ & $\begin{array}{l}\text { density / } \\
\text { denzita }\end{array}$ \\
\hline & $(\mathrm{CP})$ & (PP) & $(\mathrm{PoP})$ & & {$\left[\mathrm{km}^{2}\right]$} & {$\left[\mathrm{km}^{2}\right]$} & {$\left[\mathrm{p} .100 \mathrm{~km}^{-2}\right]$} \\
\hline Horná Orava & 24 & 5 & 7 & 36 & 587,38 & 591 & 6.1 \\
\hline Slanské vrchy Mts (south / juh) & 13 & 3 & 0 & 16 & - & 284 & 5.6 \\
\hline Laborecká vrchovina Upland & 40 & 9 & 0 & 49 & 1028,14 & 1029 & 4.8 \\
\hline Slovenský kras Mts & 10 & 2 & 0 & 12 & 438,60 & 448 & 2.7 \\
\hline Vihorlatské vrchy Mts & 7 & 4 & 0 & 11 & 482,86 & 479 & 2.3 \\
\hline Tatry Mts & 5 & 3 & 3 & 11 & 546,11 & 547 & 2.0 \\
\hline Volovské vrchy Mts & 12 & 0 & 0 & 12 & 1214,21 & 1218 & 1.0 \\
\hline Nízke Tatry Mts & 5 & 2 & 0 & 7 & 981,69 & 982 & 0.7 \\
\hline$\Sigma$ & 116 & 28 & 10 & 154 & & 5578 & \\
\hline
\end{tabular}


The suitability of the habitats and the density of breeding pairs of the lesser spotted eagle associated with it also depends on the geomorphologic characteristics of the OrU. The distribution of pairs in the individual OrU of Slovakia is shown in Fig. 10. The highest number of confirmed and probable pairs together were recorded in these OrU: Laborecká vrchovina Upland 60 , Ondavská vrchovina Upland - 60, Slanské vrchy Mts - 34, Oravská vrchovina Upland - 30, Vihorlatské vrchy Mts -24 , Beskydské predhorie Foothills -23 , Skorušinské vrchy Mts - 20, Oravská kotlina Basin 18, Podbeskydská vrchovina Upland - 18, Spišská Magura Mts - 18, etc. (Appendix 3). The highest densities with more than 5 pairs. $100 \mathrm{~km}^{-2}$ were found in these OrU (pairs.100 $\mathrm{km}^{-2}$ ): Oravská vrchovina Upland - 10.7; Skorušinské vrchy Mts - 10.3; Lubovnianska vrchovina Upland (west) - 8.6; Oravská kotlina Basin 7.9; Pieniny Mts - 7.6; Podbeskydská vrchovina Upland - 7.3; Kozie chrbty Mts - 7, Vihorlatské vrchy Mts 6.7; Podbeskydská brázda Furrow - 6.7; Slanské vrchy Mts - 6.4; Spišská Magura Mts - 5.3; Laborecká vrchovina Upland - 5.2, etc. (Appendix 4).

De term in a t i o n of bre ed ing population abundance by

2014

By 2014 the results of intensive monitoring of the breeding population of the lesser spotted eagle in the selected eight SPAs for the period from January $1^{\text {st }}$, 2011-December 31 ${ }^{\text {st }}, 2013$, were summarised in the framework of the LIFE project. In the selected project territories a total of 154 breeding pairs were recorded by 2014 , from this 116 confirmed, 28 probable and 10 possible (Tab. 3). The largest number of 49 breeding pairs was recorded in the SPA Laborecká vrchovina Upland, 36 breeding pairs in the SPA Horná Orava and 16 breeding pairs in the southern part of the SPA Slanské vrchy Mts. The largest density of breeding pairs emerged from SPA Horná Orava (6.1 pairs. $\left.100 \mathrm{~km}^{-2}\right)$, then from SPA Slanské vrchy Mts - south (5.6 pairs. $100 \mathrm{~km}^{-2}$ ) and SPA Laborecká vrchovina Upland (4.8 pairs. $100 \mathrm{~km}^{-2}$ ). Densities in the range of $1-3$ pairs. $100 \mathrm{~km}^{-2}$ were found in SPA Slovenský kras Mts (2.7 pairs.100 km-2), SPA Vihorlatské vrchy Mts. (2.3 pairs. $100 \mathrm{~km}^{-2}$ ) and SPA Tatry Mts. (2 pairs. $100 \mathrm{~km}^{-2}$ ). We recorded the smallest densities in SPA Volovské vrchy Mts. (1 pair.100 km-2) and SPA Nízke Tatry Mts. (0.7 pair.100 km-2 all Tab. 3). Figs $11-18$ present the breeding pairs distribution in the project territories by
2013. The project territories (SPAs) are ranked according to the decreasing abundance of the breeding population of the lesser spotted eagle thus: Laborecká vrchovina Upland, Horná Orava, Slanské vrchy Mts, Slovenský kras Mts, Volovské vrchy Mts, Vihorlatské vrchy Mts, Nízke Tatry Mts and Tatry Mts.

The western and southern boundaries of the associated distribution range of the breeding population of the lesser spotted eagle in Slovakia by 2014 were determined on the basis of knowledge on the breeding pairs distribution in individual DFS grid squares by an envelope curve as follows: in the direction from north to south from the state border with Poland through the cadastral territory of settlements or areas Oravská Lesná - Kubínska hol’a - Žilina - Bytča - Považská Bystrica - Púchov (Karaska in verb.) - Trenčianske Teplice - Topol'čany Klátová Nová Ves (Harvančík, Šnírer, Dubravský, Prešinský in verb.) - Nová Baňa - Pliešovce - Ábelová (Krištín in verb.) - Mýtna - Málinec - Lukovištia Teplý vrch (Kerestúr, Mojžiš in verb.) - Gemerská Ves Dlhá Ves - state border with Hungary (Dravecký, Gulak in verb.). The northern, eastern and southern boundaries of the breeding range of the lesser spotted eagle in Slovakia is formed by the state border of Slovakia with Poland, Ukraine and Hungary. This defined breeding range of the lesser spotted eagle in Slovakia covers an area of about $28,935 \mathrm{~km}^{2}$ (Fig. 19). With an estimated number of $600-800$ breeding pairs, the density is on average $2.1-2.8$ breeding pairs. $100 \mathrm{~km}^{-2}$.

Trend of development of the b reeding population in $2000-2014$

\section{Comparison of the trend of the breeding populations in SPAs}

By comparing data on the number of breeding pairs of the lesser spotted eagle from the national list of proposed SPAs (ŠOP SR 2014) and from monitoring the population of the species within the LIFE project in eight SPAs (supplemented by two other SPAs with comparable data by 2014), a total decline by 64 breeding pairs was determined by 2014 (i. e. for the period of 14 years). In relative expression this means a $26 \%$ decrease, which represents a small decrease $-1(20-49 \%)$ of abundance of the species breeding population in Slovakia (Appendix 5). If we evaluate the breeding population of the lesser spotted eagle in the 10 individual SPAs, a decline is found in eight of them for the given period and growth in the abundance occurred in 
Dravecký M, Maderič B, Topercer J, Kicko J, Danko Š, Karaska D, Guziová Z \& Šotnár K: Abundance, distribution and trend of the lesser spotted eagle (Aquila pomarina) breeding population in Slovakia
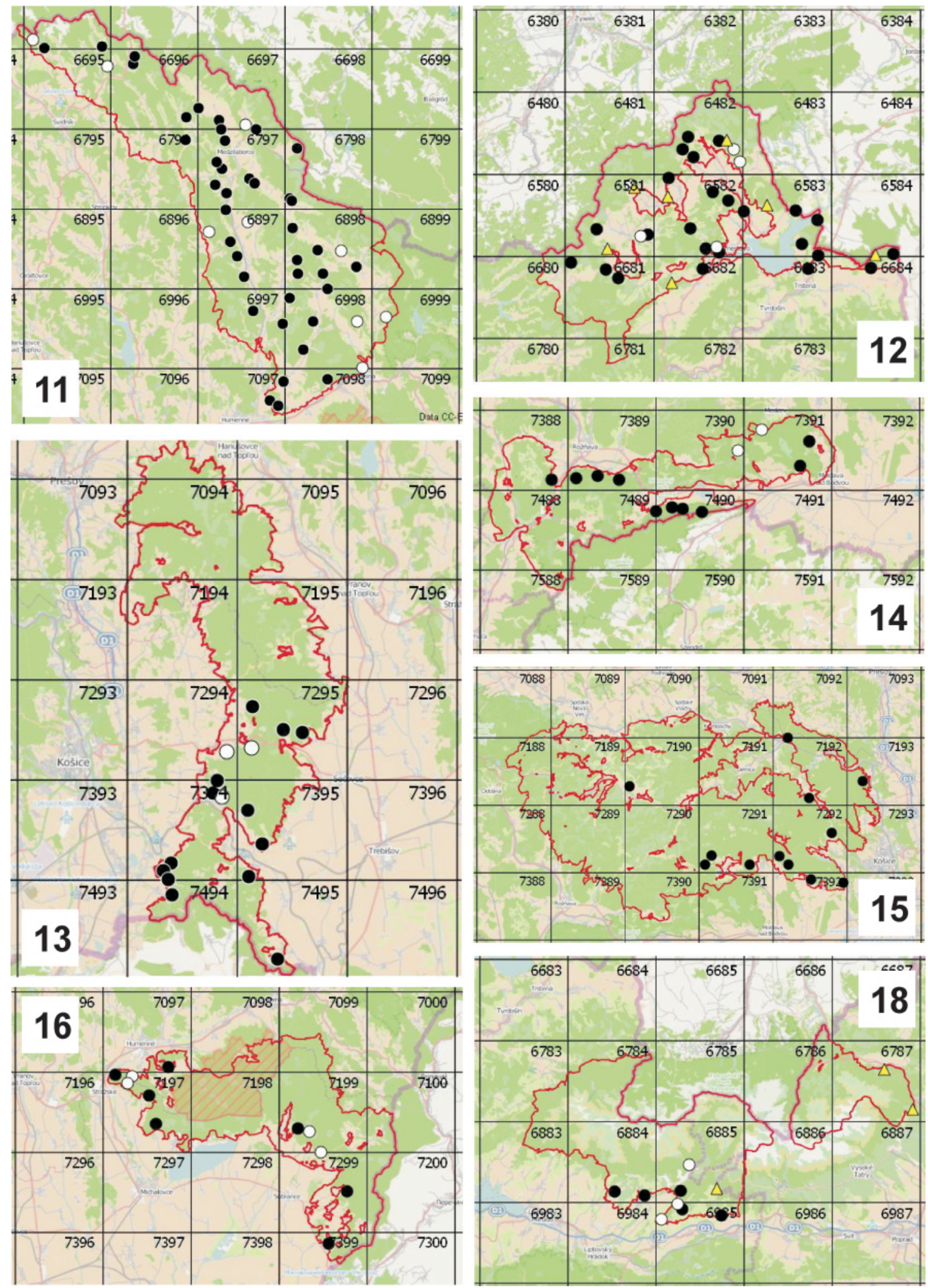


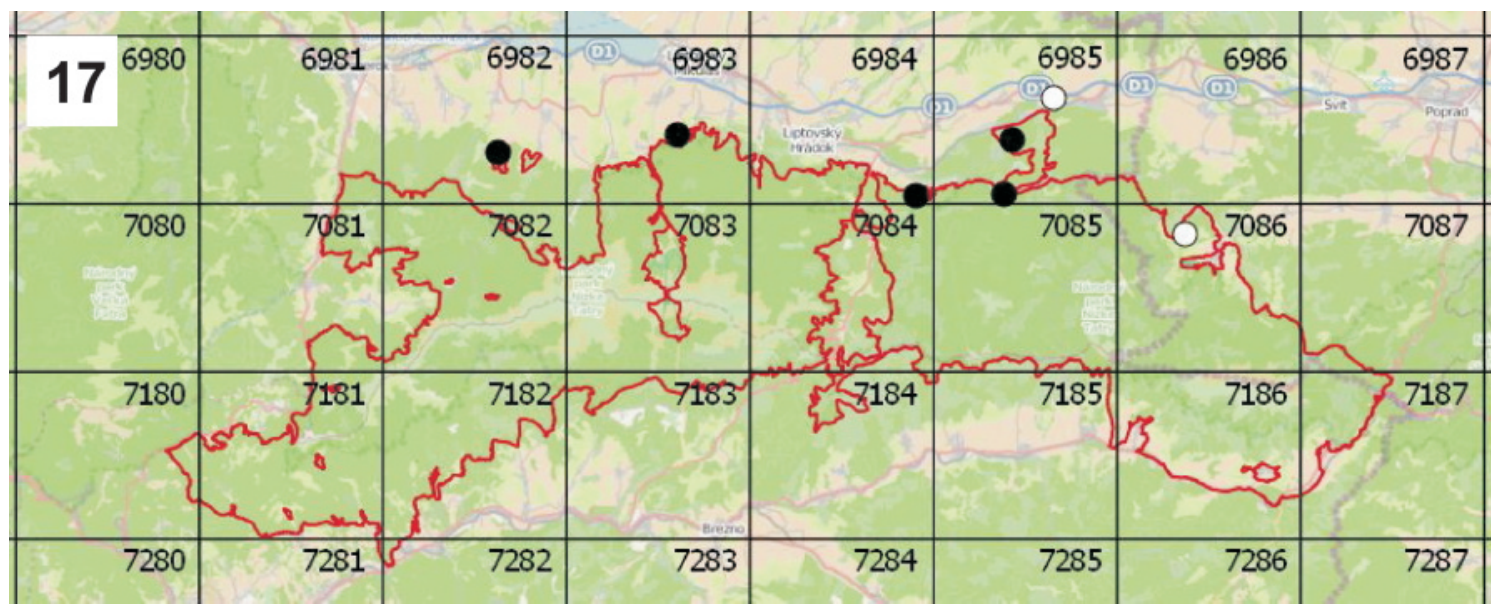

4 Figs 11-18. Distribution of breeding pairs of the lesser spotted eagle in the network of DFS squares in individual SPAs by 2013. Black circle - confirmed pairs, white circle - probable pairs, yellow triangle - possible pairs. The project territories are ranked in descending order according to abundance of the breeding population: Laborecká vrchovina Upland (11), Horná Orava (12), Slanské vrchy Mts (13), Slovenský kras Mts (14), Volovské vrchy Mts (15), Vihorlatské vrchy Mts (16), Nízke Tatry Mts (17) and Tatry Mts (18).

4 Obr. 11-18. Distribúcia hniezdnych párov orla kriklavého v sieti kvadrátov DFS v jednotlivých CHVÚ k roku 2013. Čierny krúžok - zistené páry, biely krúžok - predpokladané páry, žltý trojuholník - odhadované páry. Projektové územia sú zoradené zostupne podla početnosti hniezdnej populácie: Laborecká vrchovina (11), Horná Orava (12), Slanské vrchy (13), Slovenský kras (14), Volovské vrchy (15), Vihorlatské vrchy (16), Nízke Tatry (17) a Tatry (18).

only two of them. In three of the 10 SPAs monitored (Volovské vrchy Mts, Nízke Tatry Mts and Slovenský raj Mts) a large decrease $-2(\geq 50 \%)$ was recorded in the abundance of the breeding populations, and in the other five (Horná Orava, Slanské vrchy Mts, Vihorlatské vrchy Mts, Tatry Mts and Bukovské vrchy Mts) a small decrease -1 (20-49\%). In two SPAs we recorded growth in the abundance - small increase $+1 \quad(20-49 \%)$ in the Laborecká vrchovina Upland and large increase $+2(\geq 50 \%)$ in the Slovenský kras Mts. This method of comparing data suggests an overall negative trend in the development of the lesser spotted eagle breeding population in the selected SPAs in the category of small decrease $-1(20-49 \%)$.

\section{Comparison of the trend of breeding populations in selected well-monitored model regions}

Orographic unit Vihorlatske vrchy Mts and the adjacent territory: The territory is among the best- and longest-monitored in Slovakia in terms of checking the development of abundance and distribution of the lesser spotted eagle breeding population. The boundary of the monitored territory is depicted in the study of Danko \& Pčola (2008) with the plotting of all breeding pairs of the species found. In the 1990s 32 breeding grounds of lesser spotted eagles were recorded in this territory (the book incorrectly states that " 32 breeding pairs were found"), namely with inspected nests, where young birds were also checked. The authors assumed breeding of the species at another two breeding sites. In the year 2000 one more breeding site (33rd) was found near Modra nad Cirochou (Maderič in verb.). Twenty-three of them were located in the current SPA. It is important to note, however, that not all of the nesting sites were

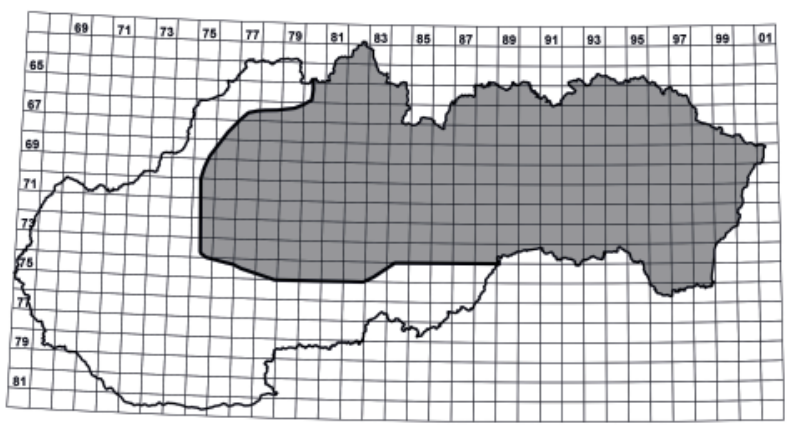

Fig. 19. The distribution range of the lesser spotted eagle breeding population in Slovakia by 2013 in the network of DFS grid squares (the area of the Slovakian part is about $28,935 \mathrm{~km}^{2}$ ).

Obr. 19. Areál rozšírenia hniezdnej populácie orla kriklavého na Slovensku k roku 2013 v sieti kvadrátov DFS (rozloha slovenskej časti areálu ca 28935 km²). 
checked in a single year. Eagles only bred one time in some nesting sites, only sporadically in some, and several traditional nesting sites began to vanish in the late 1990s. However, the authors did not have as a goal determining the maximum number of breeding pairs in one year. Danko tracked in detail only the southern part of the OrU Vihorlatské vrchy Mts with the adjacent part of the territory of the Východoslovenská pahorkatina Hills from the Ukraine border at Vyšné Nemecké Ruský Hrabovec along the Laborec River. From 1995 he recorded 20 nesting sites on this territory, at which a maximum of 15 pairs were found in 1997 and 1999. The northern part of the territory from Brekov through Zemplínske Hámre was checked by Maderič and from the village of Dlhá nad Cirochou through Ubla Dúbrava by Pčola. In 2004 Danko checked 19 nesting sites, at which 14 pairs were present, while Maderič found 4 pairs and Pčola 5 pairs. Thus, in 2004 a total of 23 nesting sites in the OrU Vihorlatské vrchy Mts were occupied by lesser spotted eagles, 17 of which were located in the current SPA. According to the monitoring in 2011-2013 within the LIFE project, a significant drop in pairs occurred in SPA Vihorlatské vrchy Mts, from 17 at the time of the proposed SPA to the current 11 pairs ( 7 confirmed and 4 probable). On the entire territory of the Vihorlatské vrchy Mts in 2013 another 7 pairs occurred outside of the SPA, but their breeding was not monitored. Overall, we recorded 18 pairs, which is a decrease of $22 \%$ versus 2004. By comparing the status in the 1990s and in the first five years of the $21^{\text {st }}$ century and the status by 2013 it is possible to reliably estimate the decline of the breeding population of the lesser spotted eagle in SPA Vihorlatské vrchy Mts at $35 \%$. A larger decline in pairs occurred in the southern part of the SPA. The assumed reason for the decline of the species in the total territory is the strong drop in the population of the common vole (Microtus arvalis), which is a fundamental element of its diet, at hunting grounds in the foothills of the Vihorlatské vrchy Mts in the Sobrance and Michalovce districts, particularly in 2009.

Orographic unit Laborecká vrchovina Upland and the adjacent territory: The territory is among the longterm and systematically monitored territories of Slovakia for the purpose of researching the ecology of the lesser spotted eagle. This includes research of its abundance, distribution, trend of the breeding population and nesting with the aim of identifying threats and ensuring a favourable status of the species population and its habitats by application of conservation management measures. Research began in 1985 and in the past ran predominately in the western part of the original district of Humenné, which included today's districts of Medzilaborce, Humenné and Snina in the orographic units Laborecká vrchovina Upland, Ondavská vrchovina Upland, Beskydské predhorie Foothills and Vihorlatské vrchy Mts, covering an area of $929 \mathrm{~km}^{2}$ (Maderič et al. 1995). Since 2006 research has been concentrated more on the territory of OrU Laborecká vrchovina Upland. Since 2009 the surveyed territory has been defined by the boundaries of the declared SPA Laborecká vrchovina Upland $\left(1029 \mathrm{~km}^{2}\right)$. By 1997 the abundance of the species' breeding population in the surveyed territory was estimated at 54 pairs. For the purpose of the List of Proposed Special Protection Areas (2003), the abundance was estimated at 38-42 pairs. On the basis of continuing intensive monitoring in subsequent periods, and mainly in 2011-2013 performed within the LIFE project, the breeding population abundance of the species in SPA Laborecká vrchovina Upland is estimated at 49 pairs. From the obtained data we can evaluate the overall trend of the lesser spotted eagle breeding population in the surveyed territory in 1997-2013 as stable, with a moderate $9 \%$ decrease. It is therefore possible to consider the breeding population as stable with oscillations in the margins of $\pm 19 \%$. A significant share of this favourable status of the population also unquestionably derives from the gradual application since 1995 of a system of protection zones around the nests of individual pairs, the aim of which is to avoid disturbing or damaging breeding habitats by restricting forest management activities on the eagles' breeding sites.

Orographic unit Volovské vrchy Mts and the adjacent territory: The Volovské vrchy Mts is among those territories with long-term monitoring of the abundance and distribution of the lesser spotted eagle in Slovakia. A description of the territory and a summary of results of the monitoring is given by Dravecký $(2000,2004 a$, b). In this territory covering an area of $1990 \mathrm{~km}^{2}$, by creation of DFS squares 71/88-92, 72/88-92, 73/88-92, $74 / 88-92$ and by extension in the OrU Volovské vrchy Mts, Slovenský kras Mts, Rožňavská kotlina Basin, Košická kotlina Basin, Revúcka vrchovina Upland and Čierna hora Mts in the 1990s, the author estimated the abundance of the breeding population of the lesser spotted eagle at $40-57$ pairs. During intensive monitoring of the species in 2011-2013 within the LIFE project, 33 breeding pairs were found in this same territory. 
Over approximately 20 years a decline of $32 \%$ occurred in the breeding population, which represents a small decrease $-1(20-49 \%)$. A sharper decrease in abundance was recorded in the current SPA Volovské vrchy Mts. Since 2003 a decrease has been recorded, from 26 breeding pairs in this territory to 12 breeding pairs in 2013 , which represents a $54 \%$ drop of the local population over the last 10 years; we can characterise this as a large decrease $-2(\geq 50 \%)$. The primary reason for this significant decline is the disturbance of nesting sites, the violation of forest vegetation integrity at the nesting sites and the overall origin of large deforested surfaces after extensive accidental felling in places of former nesting sites of the lesser spotted eagle. Also contributing in no small extent to the extinction of some breeding pairs of lesser spotted eagles was the occupying of their nesting sites by new breeding pairs of the golden eagle (Aquila chrysaetos) and the impact of interspecific competition. At the beginning of the 21 st century the nesting of the golden eagle was also recorded in the basins or at the interface of mountains and basins which before then were commonly used for breeding only by the lesser spotted eagle.

Orava Region: The Orava Region $\left(1672 \mathrm{~km}^{2}\right)$ ranks among the best- and longest-monitored territories in Slovakia. Monitoring of the lesser spotted eagle began here in 1982 and more intensively from 1986. The most attention to monitoring its population in this territory was paid in the 1990s, when the abundance was estimated at 100-120 occupied nesting sites. Individual nesting sites were stable long-term and they were moved only minimally. As early as the mid-1990s a decline began to show, particularly in the Oravská vrchovina Upland, the Skorušinské vrchy Mts and the Podtatranská brázda Furrow. Since the status of neither nesting sites nor hunting grounds were significantly changed, it is assumed this was an impact of the golden eagle, which settled in the vicinity of the then regularly occupied nesting sites of the lesser spotted eagle. At the beginning of the $21^{\text {st }}$ century, particularly by 2004 , when great windstorm damage to trees occurred that particularly affected the northern part of the region, the spruce vegetation began to dry out more intensively, particularly in the districts of Námestovo and Tvrdošín. Consequently, forest management activities intensified. The result was a wide-ranging removal of older forest vegetation, which in this territory was made up almost exclusively of spruce species. The disturbance by the forestry work was centred on fragments of older forests but also on the pressure of predators and competitors (other raptor species). The result is increased stress and subsequent departure from nesting sites (Karaska 2013). Thus, SPA Horná Orava was the most significantly affected. A three-year monitoring within the LIFE project in the SPA Horná Orava recorded a decline of the breeding population by $40 \%$ from an estimated 60 breeding pairs in the 1990s to the current 36 occupied nesting sites, which represents small decrease $-1(20-49 \%)$. In other territories the decline under the impact of forest management or the breakdown of forest vegetation is considerably less significant, and here the pressure of the golden eagle is more evident. It is possible at present to estimate the total population in the entire Orava Region at 70-90 occupied nesting sites and a decrease of approximately $27 \%$ (Karaska \& Cichocki 2014).

Horné Ponitrie Region: The first data on the lesser spotted eagle from the Horné Ponitrie Region comes from Brtek (1962), who states that several pairs fledge annually in the surroundings of Poruba and Kl'ačno (Prievidza district). Šrank \& Slobodník (1988), who present the observations of foresters from the Malá Magura Hills and the surroundings of the village of $\mathrm{Ni}$ trianské Pravno, assumed the breeding of this species to the north of the Prievidza district. It is interesting that the species is still breeding at these locations today (Šotnár 2006). In the 1990s 15 breeding pairs were estimated in the Horné Ponitrie Region $\left(960 \mathrm{~km}^{2}\right)$ and the nests of 7 of them were observed. In 2013 we estimated 20 breeding pairs for this territory, and nests were observed for 15 of them. For the monitored period the breeding population shows moderate growth of $25 \%$ which occurred approximately after the year 2000. Even though the population in this area is currently stable, for the past three years we recorded low productivity of the breeding pairs. In some of the monitored pairs the females did not sit on the nests at all, while in others females were observed sitting on nests which they later abandoned. We assume that one of the possible reasons for such behaviour is the extreme fluctuations in weather and the deficiency or inaccessibility of the primary prey, the common vole (Microtus arvalis), associated with this. We recorded a similar phenomenon in this region in the population of the common buzzard (Buteo buteo) (Šotnár \& Topercer 2009).

After analysis of the results of monitoring the development of the breeding population abundance of the lesser spotted eagle in long-term and well-monitored 

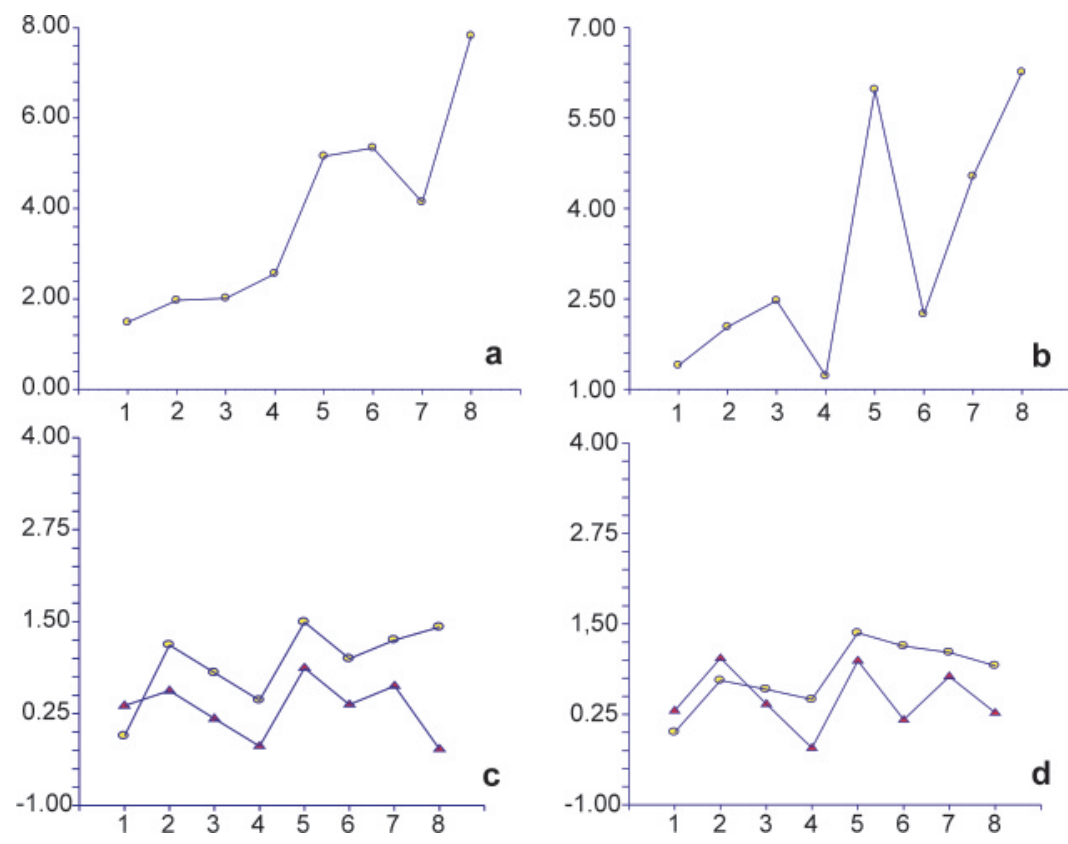

Fig. 20a-d. Average densities of all pairs of the lesser spotted eagle [pairs. $100 \mathrm{~km}^{-2}$ ] in the surveyed SPAs (1 - Nízke Tatry Mts, 2 Tatry Mts, 3 - Slovenský kras Mts, 4 Volovské vrchy Mts, 5 - Slanské vrchy Mts, 6 - Vihorlatské vrchy Mts, 7 - Laborecká vrchovina Upland, 8 - Horná Orava) by 1997 (a) and 2013 (b). Effect of the observer (yellow circle - the same observer, red triangle - different observers) (c) and year (yellow circle - 1997, red triangle - 2013) (d) in the categories of number of all pairs ( $y$ axis) according to individual SPA (x-axis).

Obr. 20a-d. Priemerné hustoty všetkých párov orla krikl'avého [páry.100 km-2] v skúmaných CHVú (1 - Nízke Tatry, 2 - Tatry, 3 - Slovenský kras, 4 - Volovské vrchy, 5 - Slanské vrchy, 6 - Vihorlatské vrchy, 7 Laborecká vrchovina, 8 - Horná Orava) k roku 1997 (a) a 2013 (b). Efekt pozorovatel'a (žltý krúžok - ten istý pozorovatel', červený trojuholník - rozdielni pozorovatelia) (c) a roka (žltý krúžok - 1997, červený trojuholník - 2013) (d) v kategóriach počtu všetkých párov (os y) podla jednotlivých CHVÚ (os x).

regions, we can state that the central tendency in them is about a $20 \%$ decrease, in the category of small decrease -1 (20-49\%) (Appendix 6).

B reeding pair numbers and p o p u lat i o n t r e n d s

Since SPAs may vary in the proportion of "edge" DFS squares (intersected by a SPA boundary), we tested the significance of differences in the proportion of these squares among the surveyed SPAs. Kruskal-Wallis ANOVA showed no significant differences $\left(\mathrm{H}_{0.05,7,111}=\right.$ $3.681 ; p=0.816)$ and indicates that there will be no significant differences also in the strength of edge effect affecting the density of the lesser spotted eagle.

The same ANOVA technique yielded highly significant differences in the densities of all pairs in the DFS squares among the surveyed SPAs by $2014\left(\mathrm{H}_{0.05,7,111}=\right.$ 25.218; $p=0.0007$; Fig. 20b) and by 1997 (Fig. 20a) when, however, the results did not meet the assumption of equal variances (modified Levene test; $\mathrm{W}_{0.05,7,111}=$ 2.905; $\mathrm{p}=0.008$ ). By 2014 the median density in SPA Slanské vrchy Mts - south (6 pairs. $100 \mathrm{~km}^{-2}$ ) was significantly greater than in Nízke Tatry Mts (Kruskal-Wallis multiple comparison $\mathrm{z}$-value test; $\mathrm{z}_{0.05,7,111}=3.536$; $\mathrm{p}<$ $0.05)$ and in Volovské vrchy Mts $\left(\mathrm{z}_{0.05,7,111}=3.286\right.$; $\mathrm{p}<$ $0.05)$. The differences in the numbers of occupied DFS squares between the individual SPAs by 2014 are also significant $\left(\mathrm{H}_{0.05,7,111}=22.127 ; \mathrm{p}=0.002\right)$. The fact that by 1997 this was not the case $\left(\mathrm{H}_{0,05,7,111}=11,873\right.$; $\mathrm{p}=$ 0.105 ) and that by 2014 the median numbers of occupied DFS squares in Slanské vrchy Mts $\left(\mathrm{z}_{0.05,7,111}=\right.$ 3.406; $\mathrm{p}<0.05$ ) and Laborecká vrchovina Upland $\left(\mathrm{z}_{0.05,7,111}=3.343 ; \mathrm{p}<0.05\right)$ were significantly greater just than those in Nízke Tatry Mts may point to either a significant change in the distribution of local population between the reference periods or a significant effect of the interobserver variability. We shall attempt to address this question below.

Agglomerative cluster analysis of the numbers of all pairs (NAP) in both periods using unweighted pair group means (UPG) gave the best results (the largest cophenetic correlation coefficient of 0.93 with relatively smallest distortion $\delta_{0.5}=0.213$ ). At the highest dissimilarity level (2.82) clusters of the most densely inhabited DFS squares from SPA Horná Orava and SPA Laborecká vrchovina Upland separate from other SPAs with markedly lower mutual dissimilarities (1.463 and less), which is supported by the results of divisive fuzzy algorithm. Such a dissimilarity pattern, together with the above Kruskal-Wallis ANOVA tests, allows the analysed set of eight SPAs to be divided into two subsets:

1) the Palaeogene (flysch) mountains of the Nízke Beskydy Mts, Poloniny Mts, Podhale-Magura Area, Východné Beskydy Mts and the Orava part of Stredné Beskydy Mts (Mazúr \& Lukniš 1986), represented by SPA Horná Orava and SPA Laborecká vrchovina Upland; 
2) the other mountains of the Východné and Západné Karpaty Mts, represented by the remaining six SPAs with significantly lower densities and more uneven distribution of the lesser spotted eagle.

These two units along with their utility in stratification and extrapolation of population densities and trends may also have zoogeographical and/or macroecological relevance.

Tests of differences in distributions and numbers between the two reference periods (by 1997 and 2014) were in favour of $1997(1997>2014)$ but gave only marginally significant results, regardless of whether the NAP (Mann-Whitney $U$ test; $\mathrm{z}_{0.05,1,236}=1.452 ; \mathrm{p}=$ $0.07)$, densities $\left(\mathrm{z}_{0.05,1,236}=1.522 ; \mathrm{p}=0.06\right)$ or numbers of occupied DFS squares $\left(\mathrm{z}_{0.05,1,236}=1.553 ; \mathrm{p}=0.06\right)$ were involved. So though the changes appear to be significantly negative (particularly in the distribution), for more conclusive results an even larger and/or more representative sample of SPAs would be needed.

Also loglinear models suggest no significant role of changes between the two periods (by 1997 vs 2014). A model of relationships between the response NAP ( 5 categories) and three predictors (period, observer and site, i.e. SPA) revealed significant effects only in observer $\left(\chi_{0.05,1,2}^{2}=113.33 ; \mathrm{p}<0.001\right)$, site $\left(\chi_{0.05,7,9}^{2}=\right.$ 46.93; $\mathrm{p}<0.001)$ and their interaction $\left(\chi_{0.05,7,16}^{2}=\right.$ $145.92 ; \mathrm{p}<0.001)$, but not in period $\left(\chi_{0.05,1,2}^{2}=1.45\right.$; $\mathrm{p}=0.229$ ). Even a Poisson regression model with the same variables, controlled for a confounding effect of partitioning the SPAs by a DFS grid adequately fitting the data (Pearson lack-of-fit test; $\chi^{2}{ }_{0.05,9,229}=220.66 ; \mathrm{p}=$ 0.642 ) and explaining c. $25 \%$ of variability in the response (pseudo- $\mathrm{R}^{2}=0.251$ ), demonstrated significant effects only in observer (deviance test; $\chi_{0.05,1,3}^{2}=21.35$; $\mathrm{p}<0.001)$ and site $\left(\chi_{0.05,79}^{2}=53.39 ; \mathrm{p}<0.001\right)$. These include inverse relationships in the case of Nízke Tatry Mts (regression coefficient $b_{1}=-1.557$; Wald's $\chi_{0.05,79}^{2}=$ 26.1; $\mathrm{p}<0.001)$, Tatry Mts $\left(\mathrm{b}_{2}=-1.046\right.$; Wald's $\left.\chi_{0.05,7,9}^{2}=11.15 ; \mathrm{p}=0.001\right)$, Slovenský kras Mts $\left(\mathrm{b}_{3}=\right.$ -0639; Wald's $\left.\chi_{0.05,7,9}^{2}=4.85 ; \mathrm{p}=0.028\right)$ and Volovské vrchy Mts $\left(\mathrm{b}_{4}=-1.235\right.$; Wald's $\chi_{0.05,7,9}^{2}=23.73 ; \mathrm{p}<$ $0.001)$. We came to a similar conclusion using general linear models in the form of analysis of covariance (ANCOVA). The same three-predictor model, while controlling for a significant effect of partitioning the SPAs by the DFS grid $\left(\mathrm{F}_{0.05,1,205}=109.94 ; \mathrm{p}=0.000\right)$, assigned significance only to the effect of site $\left(\mathrm{F}_{0.05,7,205}=5.92 ; \mathrm{p}<0.001\right)$, not to period or observer. But as it violates some principal assumptions (particu- larly the normality of residuals), we present here only two figures illustrating the effect sizes of observer (Fig. 20c) and period (Fig. 20d) by the individual SPAs.

When extrapolating the breeding pair numbers, population densities and trends of the lesser spotted eagle by 2014 to its entire breeding range in the Slovak Republic we drew on the data summarised in Tab. 4 (numbers and densities), Appendix 5 (trends) and Appendix 7, on the extent of its range in Slovakia (Fig. 19; c. $28,935 \mathrm{~km}^{2}$ ) and on its stratification relying on the above results. The two already outlined approaches were used. First, for the eight SPAs we calculated interval estimates of the arithmetic mean varying from 0.7 to 6.4 pairs.100 $\mathrm{km}^{-2}$ (mean 2.9, median 2.38), second yielded the interval estimates of the arithmetic mean varying from 1.2 to 6.3 pairs. $100 \mathrm{~km}^{-2}$ (mean 3.27 , weighted arithmetic mean 3.07, median 2.36) and median ranging from 0 to 6.4 pairs. $100 \mathrm{~km}^{-2}$ (mean 2.02, weighted arithmetic mean 1.82, median 0.66). By summarising these estimates and linearly extrapolating to the species' breeding range in Slovakia as a whole or stratified into flysch vs the remaining part (see above) while stepwise increasing sample size $(\mathrm{n}=8,9,11$ and 12 SPAs), the size estimates stabilise at a level of 670 (arithmetic mean with 95\%LCL $=507$ and $95 \% \mathrm{UCL}=$ 834 ) or 765 (median with 95\%LCL $=393$ and $95 \% \mathrm{UCL}=841)$ breeding pairs. The rather wide confidence intervals in both cases reflect the considerable spatial variation in the distribution and density of our breeding population as well as the limited sample size. Since data distribution (particularly due to skewness) slightly departs from normality (D'Agostino-Pearson skewness test; $\left.\mathrm{z}_{0.05,10}=-1.99 ; \mathrm{p}=0.046\right)$ and arithmetic means were less stable as the sample size increased, we take as the most reliable estimate of the breeding population size of the lesser spotted eagle in Slovakia by 2014 the median of 765 pairs with a 95\% confidence interval from 393 to 841 pairs and variability (interquartile range) from 418 to 835 pairs. From this we can get the rough estimate of the breeding population size in Slovakia by 2014 at c. $420-840$ breeding pairs, which is in good agreement with an estimate of $600-800$ breeding pairs derived above.

The summarised trends in the breeding population size of the lesser spotted eagle in Slovakia over the period 2000-2013 exhibit an overall decrease on average of $-23 \%$. In some areas the decreasing trend is even more pronounced (median -35\%, Appendix 5), as in the sample of eight SPAs ranging from $-53.85 \%$ to $50 \%$ 
(arithmetic mean $-20.94 \%$, median $-35.98 \%$ ) and in the sample of 10 SPAs ranging from $-55.56 \%$ to $50 \%$ with the arithmetic mean $-25.38 \%$, weighted arithmetic mean $-24.8 \%$ and median $-35.3 \%$. The first and third of these mean values (i.e. arithmetic mean with $95 \% \mathrm{LCL}=$ $-50.66 \%$ and $95 \% \mathrm{UCL}=-0.11 \%$ and median with $95 \% \mathrm{LCL}=-53.85 \%$ and $95 \% \mathrm{UCL}=25 \%$ ) we regard as minimum bias estimates of the population trend, taking into account the quality of the available data. The not too narrow confidence intervals here also point both to the substantial spatiotemporal variation in the breeding population trends and the restricted sample size. Since data distribution here also departs from normality (D“Agostino-Pearson skewness test; $\mathrm{z}_{0.05,10}=2.08 ; \mathrm{p}=$ 0.038 ) and medians show notably higher stability than the arithmetic means as the sample size increased, we take as the most reliable estimate of the trend in the breeding population size of the lesser spotted eagle in Slovakia over the period 2000-2013 the median trend of $-35 \%$ (small decrease) with the $95 \%$ confidence interval from $-54 \%$ to $+25 \%$.

Abundance, distribution and trend are important and frequently used ecological attributes in research of bird populations. This problem has also been studied longterm with the lesser spotted eagle in Slovakia. From the $1950 \mathrm{~s}$ to the start of the $21^{\text {st }}$ century growth in the abundance of the species' breeding population was recorded in Slovakia (Karaska \& Danko 2002), from 75-120 pairs (Sládek 1955, Mošanský 1972, Voskár 1976, 1977) up to 800-900 pairs after the estimate of abundance by 2000 . The mentioned growth of the breeding population is more associated with a growth in knowledge of the species connected with intensive monitoring, an increased number of observers, the origin of the specialised Group for Research and Protection of Raptors and Owls (SVODAS) or an increased number of observers involved in specialised censuses for the atlas of breeding distribution of species (Danko et al. 2002) than with actual growth of the breeding population by enlarging the distribution range or increased breeding success. Such a trend has also been recorded in other countries. For a comparison of the abundance of the breeding population of the lesser spotted eagle in Slovakia with other countries in the areas of species distribution we can compare data from four published sources from different periods: 1) from 1990-1996, the European action plan for the lesser spotted eagle (Meyburg et al. 2001), 2) from 1990-1996 Meyburg (1996), 3) from 1995-2002 (BirdLife 2004), 4) from 2000-2013 (Krumenacker 2013) (Appendix 8).
In some countries the abundance of the breeding population grew rapidly, e.g. in Romania from an estimate of 100 breeding pairs in 1996 in the European action plan for the lesser spotted eagle (Meyburg et al. 2001), which was doubtful and subsequently modified to 2000 breeding pairs by Meyburg (1996), to the current estimated number of a breeding population of 2500-2800 pairs (BirdLife 2004, Krumenacker 2013). Similarly in Ukraine an estimate of 200-250 pairs in the European action plan for the lesser spotted eagle (Meyburg et al. 2001), modified to 800 pairs by Meyburg (1996), later to $500-1000$ breeding pairs (BirdLife 2004) and finally 1500 breeding pairs (Krumenacker 2013); in Poland an estimate of 1660-1850 breeding pairs in the European action plan (Meyburg et al. 2001), later 1700-1900 (BirdLife 2004) and at present now 2300-2800 breeding pairs (Krumenacker 2013); in Lithuania an estimate of 500-730 in the European action plan (Meyburg et al. 2001), later 900-1200 (BirdLife 2004) and at present 1500-1800 breeding pairs (Krumenacker 2013); in Bulgaria an estimate of $60-120$ breeding pairs in the European action plan (Meyburg et al. 2001), doubtful and subsequently modified to 1300 pairs by Meyburg (1996), later again modified to $120-200$ pairs in 1996-2002 (BirdLife 2004) and finally at present a valid estimate of 500 breeding pairs (Krumenacker 2013). In Latvia by 1996 a total of 2000-2800 breeding pairs was estimated and given in the European action plan (Meyburg et al. 2001). For 1990-2000 the estimate was modified to 2800-5200 (BirdLife 2004) and finally in 2013 a total of 3600 breeding pairs is estimated (Krumenacker 2013).

In all of these presented countries growth was recorded in abundance of the breeding population in 1990-2013, thus, for the past roughly 20 years, which, however, likely coincided, as in Slovakia, with the growth of knowledge of the population of the species due to intensive monitoring. Some countries, however, have maintained approximately the same breeding population size, with possible smaller deviations from 1990-2013, such as, for example, Belarus with an estimated number of pairs at $3250 \pm 100$ by 1996 in the European action plan (Meyburg et al. 2001) and a moderate increase to 3200-3800 pairs (BirdLife 2004, Krumenacker 2013), Armenia with estimates of 35-40 pairs (Meyburg et al. 2001) and 48-52 pairs (Krumenacker 2013), Azerbaijan with an estimated 100 pairs (Meyburg et al. 2001) and 20-100 pairs (BirdLife 2004), and Georgia with an estimate 85 (Meyburg et al. 2001) and 60-70 pairs (BirdLife 2004, Krumenacker 2013). 
Some countries with long-term intensive monitoring, however, give an ongoing gradual decline in the number of breeding pairs and call attention to the overall negative trend in the development of the breeding population of the lesser spotted eagle in the species distribution range in Europe. For example, in Germany from the year 1800 to the present the species distribution range has decreased from $83,000 \mathrm{~km}^{2}$ to the present $10,000 \mathrm{~km}^{2}$. The western boundary of the species distribution range has shifted markedly to the east. In 1996 130 breeding pairs were registered, and later in 2001 only 115 (Meyburg et al. 2004) and in 2013 only 102 breeding pairs (!) (Krumenacker 2013). Meyburg et al. (2008) present for the period 1993-2007 a continuous decline in abundance of the breeding population in Germany by $23 \%$. In the Czech Republic the size of the breeding population was estimated at 2-5 pairs (Meyburg et al. 2001), but later no breeding of the species was recorded and only the occurrence of the lesser spotted eagle was registered (BirdLife 2004); at present just 1 breeding pair is listed (Krumenacker 2013). All of the presented information points to a decrease in the overall species range. In Hungary an even more significant decrease in the abundance of the breeding population was recorded. While in 1996 Haraszthy et al. (1996) and Meyburg et al. (2001) presented the number at 150 pairs, in the subsequent period from 1995-2002 only 30-60 pairs were given, which represents a $50-79 \%$ decrease in the population (BirdLife 2004). By 2013 (Krumenacker 2013, BirdLife 2004) the number of breeding pairs in Hungary was listed at $40-45$ pairs. Szegedi et al. (2010) estimate by 2008 the size of the breeding population of the lesser spotted eagle in Hungary at 37 pairs and Pongrácz et al. (2012) by 2010 at $30-39$ breeding pairs.

In the former Czechoslovakia and subsequently in the Czech and Slovak Republics it is also possible to track the decreasing species breeding distribution range

Fig. 21a-e. Comparison of the boundaries of the breeding distribution range of the lesser spotted eagle population in Slovakia (and in the former Czechoslovakia) in 1970-2013: a 1973/1977 (Št’astný et al. 1987), b - 1970-1990 (Danko et al. 1994), c - 1980-1999 (Karaska \& Danko 2002), d - 1980-2000 (Korňan et al. 2003), e - 2013 (this study).

Obr. 21a-e. Porovnanie hraníc rozšírenia hniezdnej populácie orla kriklavého na Slovensku (a v bývalom Československu) v rokoch 1970-2013: a - 1973/1977 (Štastný et al. 1987), b 1970-1990 (Danko et al. 1994), c - 1980-1999 (Karaska \& Danko 2002), d - 1980-2000 (Korňan et al. 2003), e - 2013 (táto štúdia).
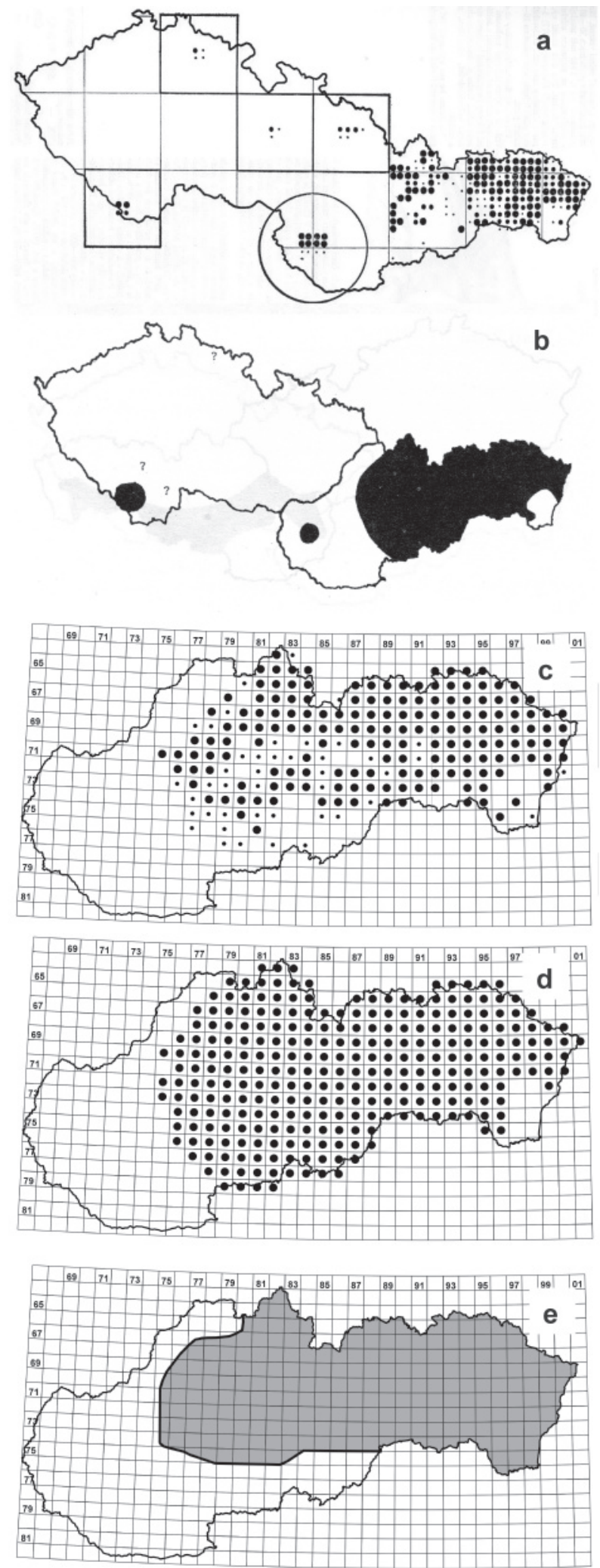
and the shift of its western boundary on the axis of Germany, Czech Republic, Slovakia and Hungary to the east. On a species distribution map from the 1970s in what was then the Czechoslovak Socialist Republic (Št'astný et al. 1987) (Fig. 21a) breeding occurrences in Czech Republic (in the former Czechoslovakia) are shown in the Sumava Mts and at three other sites (Št'astný et al. 1987) and the number of breeding pairs at 4-5 (Meyburg et al. 2001). However, in 2001-2003 no breeding pairs of the species were recorded in Czech Republic, and the lesser spotted eagle is now considered to be regionally extinct (Št'astný \& Bejček 2003, Št’astný et al. 2003). In 2010-2013 the breeding of 1 pair was again recorded in the Czech Republic (Bělka in verb.). Likewise, in Slovakia in the 1970s (Š́tastný et al. 1987) (Fig. 21a) a breeding occurrence of the species is shown in the Malé Karpaty Mts, which was also shown on a map for the years 1980-1990 (Danko et al. 1994) (Fig. 21b). The last confirmed breeding in the Malé Karpaty Mts was recorded at the Zvernica site in the territories of the villages Píla and Kuchyña in 1980 (Chavko in Korñan et al. 2003). Since then, the lesser spotted eagle has not bred in the Malé Karpaty Mts and the boundary of its distribution in Slovakia has shifted further to the east. In the scope of a questionnaire in 1997 a probable breeding of the lesser spotted eagle was recorded in 1986-1996 in the Javorníky and Považský Inovec Mts, that is, on the western-most known breeding sites of this species in Slovakia. By 2013 the species with certainty was not breeding in the Považský Inovec Mts (Prešinský in verb.).

On a map of the species breeding distribution in 1980-1990 (Danko et al. 1994) (Fig 21b), as well as in the Rescue Programme for the Lesser Spotted Eagle (Korňan et al. 2003) (Fig 21d) the boundary of continuous breeding distribution is shown by an arc from Poland in the north down through the Hungarian border to the south of central Slovakia, while also including the orographic units of the Ipelská, Lučenecká and Rimavská kotlina Basins. A map of the distribution of the lesser spotted eagle in Slovakia by 2014 (Fig. 21e, Fig. 19) excludes this territory from the species distribution range in Slovakia. The species breeding distribution in this area has never been sufficiently surveyed exactly and the southern boundary of the species distribution range in central Slovakia was for a long time unclear. By 2014 the southern boundary of the species distribution range is defined by DFS grid squares in lines $75 / 75-84$ and $74 / 85-89$ (Fig. 19). The edges of this line by 2014 were confirmed to the south of central Slovakia by long-term bird monitoring in the Štiavnické vrchy Mts, the Pliešovská kotlina Basin, the Krupinská vrchovina Upland (Krištín in verb.) and the Ipel'ská, Lučenecká and Rimavská kotlina Basins, with the exclusion of breeding at present, but also in the preceding years (Kerestúr \& Mojžiš in verb.). Therefore, the correctness of delinating the boundary of the species distribution also with the whole of south-central Slovakia up to the border with Hungary on the species distribution maps of Danko et al. (1994) (Fig. 21b) and Korňan et al. (2003) (Fig 21d) is questionable. Karaska \& Danko (2002) (Fig. 21c) on a species distribution map in Slovakia present under the line of DFS grid squares $75 / 77-88$ only 1 confirmed breeding, in DFS grid square 76/81, and in another six (DFS grid squares 76/77, 76/79, 77/79-80, 79/82, 79/84) with probable breeding. An observed occurrence of an individual does not necessarily mean breeding, mainly if the observation of the individual occurs during the migratory season or concerns non-breeding adult individuals or immature individuals from this or other regions of the breeding range which are lingering on the territory of Slovakia (Dravecký et al. 2013). Upon comparing a species distribution map from the years 1980-1990 (Danko et al. 1994) (Fig. 21b), (Korňan et al. 2003) (Fig. 21d) with a distribution map by 2013 (Fig. 21e) the boundary of the distribution range in the south of central Slovakia is shifted from the state border with Hungary north to the line of DFS grid squares 75/75-84 and 74/85-89. The boundary of the species distribution range should be concurrently monitored and each breeding beyond this boundary should be thoroughly documented. The shift of the species breeding distribution is closely associated with the trend of development of the local breeding population.

Among the new and interesting findings in this study, besides more accurate and reliable breeding population estimates, one can also include some ecological, zoogeographical and methodological implications:

- The likely differentiation of the West Carpathian part of the species' breeding range into an area of flysch mountains vs other mountains having remarkably lower densities and a more uneven distribution of the population.

- Very wide variability in the breeding pair numbers and densities between the regions (OrU) in contrast to the rather limited variability between the periods by 1997 vs 2014 (we were unable to detect any significant effect of the differences between these periods). 
- Different behaviour of the population metrics used (numbers of occupied DFS grid squares vs numbers and densities of breeding pairs in them) obviously also reflecting differences in the set of factors determining distribution vs abundance of the breeding population.

- To estimate the significance of differences between periods (and perhaps also in trends) more accurately and reliably, even a larger and/or more representative sample of the monitored SPAs would be necessary, taken primarily from other than flysch or east Slovakian volcanic mountains.

By 2014 we estimate the abundance of the lesser spotted eagle breeding population in Slovakia at 600-800 pairs and a declining trend of the population in $2000-2013$ on average by $-23 \%$. Our estimate is substantiated by the results of extrapolation of data obtain in 2011-2013 from the eight selected SPAs in the scope of the LIFE project. We estimate a $23 \%$ decrease in the Slovakia-wide population in 2000-2013, which represents a small decrease $-1(20-49 \%)$.

The given achieved results are in agreement with knowledge on the decline of abundance of breeding populations in the countries on the western boundary of the species distribution range, i. e. in Germany, Czech Republic, Hungary and Slovakia. With respect to the above-given facts, knowledge will be important regarding the development of breeding population abundance and their trends in the core regions of the species distribution range in northern Europe, for example, in Latvia, Belarus, Poland, Lithuania and Estonia, or in southern Europe, in Romania and Ukraine, where there are the most abundant populations of the lesser spotted eagle in the world.

The problem of differences in the numbers of migrating individuals of the species to wintering grounds in central and southern Africa and back obtained by long-term systematic counting from observation outposts in Israel and an estimate of abundance of the species breeding population in Europe has been discussed in several publications - most recently in the paper of Krumenacker $(2012,2013)$. The author points to the fact that from a long-term point of view the average numbers of counted individuals of this species in Israel are higher than the estimated breeding populations in Europe, and that the current estimate of the abundance of the breeding population in Europe at 20,000 pairs (BirdLife 2004) is moderately underestimated (Krumenacker 2012, 2013). The total number of breeding pairs in Europe in 2013 by summation of the num- bers of breeding pairs in individual countries (Appendix 8 ) is estimated at $18,038-23,201$. According to the results obtained by counting individual during migration in Israel in the years 1982-2012, the breeding population abundance of the species in Europe should achieve 25,000-31 000 pairs, which represents 2,000-13,500 pairs more than is the estimate at present (Krumenacker 2012, 2013).

\section{C o n c l u s i o n}

Abundance, distribution and trend of the breeding population are key ecological attributes used in the development of European Species Action Plans, the goal of which is to ensure protection of the endangered species populations and their habitats. The European Union Species Action Plan for the lesser spotted eagle was published in 2001 (Meyburg et al. 2001). In 2013 in Romania the process began of updating this Action Plan as the European Recovery Plan for the lesser spotted eagle, and it continues in 2014. When updating the European Recovery Plan, the focus should be on the most recent knowledge about the ecology and about conservation of the lesser spotted eagle breeding population in Europe. The mentioned update of the strategic document should consider scientific data on abundance, distribution and trend of the breeding populations in the individual countries of Europe, data on factors having a negative impact on the survival of the species and proposals for conservation management measures aimed at eliminating these negative factors not only on a European level, but also in countries outside Europe, where there is continous threat of illegal shooting during migration of the species to its wintering grounds in central and southern Africa. We firmly believe that this study on abundance, distribution and trend of the lesser spotted eagle breeding population in Slovakia in 1980-2013 contributes to a significant extent to knowing and protecting this species not only on a national but also on an international level in the development of an updated European Recovery Plan for the lesser spotted eagle.

\section{References}

Baruš V 1981: Návrh seznamu ohrožených taxonů obratlovců (Vertebrata) fauny ČSSR [Proposal of a List of Endangered Vertebrate Taxa in the Fauna of Czechoslovakia]. Vertebratologické zprávy: 35-42. [In Czech]

Baruš V, Donát P, Trpák P, Zavázal V \& Zima J 1988: Red Data List of Vertebrates of Czechoslovakia. 
Acta scientiarum naturalium Academiae scientiarum bohemoslovacae Brno, series nova, 22(3): 1-33. [In English with Russian summary]

Baruš V, Bauerová Z, Kokeš J, Král B, Lusk S, Pelikán J, Sládek J, Zejda J \& Zima J 1989: Červená kniha 2 - ohrožených a vzácných druhů rostlin a živočichů ČSSR. Kruhoústí, ryby, obojživelníci, plazi, savci. Ptáci. [Red Book 2 - endangered and rare species of flora and fauna of Czechoslovakia. Cyclostomes, fish, amphibians, reptiles, mammals. Birds]. Státní zemědělské nakladatelství, Praha, 136. [In Czech with Russian, English and German summaries]

Bělka T 2014: Orel křiklavý v České republice [Lesser Spotted Eagle in the Czech republic], 13. In: Anonymus (ed), Umíme žít s orly? Aneb jak se daří orlům v Česku a na Slovensku. Sborník př́íspěvků z konference, 12. března 2014, Zoologická zahrada Ostrava, 34. [In Czech]

Bergmanis U, Drobelis E, Karaska D 1997: Aquila pomarina, Lesser Spotted Eagle, 164-165. In: Hagemeijer EJM \& Blair MJ (eds), The EBCC Atlas of European breeding birds - their distribution and abundance. T and AD Poyser, London, 904.

BirdLife International 2004: Birds in Europe: population estimates, trends and conservation status. Cambridge, UK: BirdLife International. (BirdLife Conservation Series No. 12), 374.

BirdLife International (2014) Species factsheet: Aquila pomarina. Downloaded from http://www.birdlife.org on 01/04/2014.

Bohačík L 1976: Výskyt orlov v Turci [Occurrence of eagles in the "Turiec" region]. Kmetianum 4: 271-276. [In Slovak with English summary]

Bohačík L 1988: Š́renie orla krikl’avého (Aquila pomarina Brehm) $\mathrm{v}$ Turci [Extension of the lesser spotted eagle (Aquila pomarina Brehm) in the "Turiec" region]. Správy Slovenskej Zoologickej Spoločnosti SAV 14: 48-49. [In Slovak]

Brtek J \& Vachold J 1962: K výskytu niektorých pozoruhodných živočíchov na Hornej Nitre [The occurrence of some remarkable animals in the Upper Nitra]. Horná Nitra 1: 239-245. [In Slovak]

Bosch J \& Meyburg B-U 2012: The lesser spotted eagle Aquila pomarina in Catalonia (Spain) - Breeding attempt and migration. Vogelwelt 133: 89-97.

Danko Š 1976: Správa o činnosti Skupiny pre výskum dravého vtáctva a sov za r. 1975 [Report on activity of Group for Research of Birds of Prey and Owls in
1975]. Unpublished document, 8. [Depon. in Group for Research of Raptors and Owls, Michalovce]. [In Slovak]

Danko Š 1977a: Správa o činnosti Skupiny pre výskum dravého vtáctva a sov v Československu za roky 1975 a 1976 [Report on activity of Group for Research and Protection of Birds of Prey and Owls in Czechoslovakia in 1975 and 1976], 93-104. In: Randík A (ed), Falconiana I. Súbor referátov zo seminára "Súčasný stav rozšírenia a ochrany dravých vtákov v Československu", Nitra, 24.-25. septembra 1976 [Falconiana I. Proceedings from seminar "Current state of distribution and protection of raptors in Czechoslovakia", Nitra, September 24-25, 1976]. Ústav experimentálnej fytopatológie a entomológie SAV, Sekcia ochrany fauny Slovenskej zoologickej spoločnosti SAV \& Sekcia ochrany vtáctva Československej ornitologickej spoločnosti, Bratislava, 107. [In Slovak with German summary]

Danko Š 1977b: Správa o činnosti Skupiny pre výskum dravého vtáctva a sov v ČSSR za rok 1976 [Report on activity of Group for Research of Birds of Prey and Owls in Czechoslovakia in 1975]. Unpublished document, 9. [Depon. in Group for Research of Raptors and Owls, Michalovce]. [In Slovak]

Danko Š 1978: Správa o činnosti Skupiny pre výskum dravého vtáctva a sov za rok 1977 [Report on activity of Group for Research of Birds of Prey and Owls in Czechoslovakia in 1977]. Unpublished document, 10. [Depon. in Group for Research of Raptors and Owls, Michalovce]. [In Slovak]

Danko Š 1979: Správa o činnosti za rok 1978 [Report on activity in 1978]. Unpublished document, 12. [Depon. In Group for Research of Raptors and Owls, Michalovce]. [In Slovak]

Danko Š 1980: Správa o činnosti za rok 1979 [Report on activity in 1979]. Unpublished document, 11. [Depon. in Group for Research of Raptors and Owls, Michalovce]. [In Slovak]

Danko Š 1987: Správa o činnosti Skupiny pre výskum a ochranu dravcov a sov v ČSSR za rok 1985 [Report on the Activity of the Group for Research and Protection of Birds of Prey and Owls in Czechoslovakia in 1985]. Skupina pro výzkum dravých ptáků a sov, Zprávy 6: 1-25. [In Slovak]

Danko Š 1988: Správa o činnosti Skupiny pre výskum a ochranu dravcov a sov v ČSSR za rok 1986 [Report on the Activity of the Group for Research and Pro- 
tection of Birds of Prey and Owls in Czechoslovakia in 1986]. Buteo 1 [1986]: 3-31. [In Slovak with English summary]

Danko Š 1989: Správa o činnosti Skupiny pre výskum a ochranu dravcov a sov v ČSSR za rok 1987 [Report on the Activity of the Group for Research and Protection of Birds of Prey and Owls in Czechoslovakia in 1987]. Buteo 2 [1987]: 1-36. [In Slovak with English summary]

Danko Š 1990: Správa o činnosti Skupiny pre výskum a ochranu dravcov a sov v ČSSR za rok 1988 [Report on the Activity of the Group for Research and Protection of Birds of Prey and Owls in Czechoslovakia in 1988]. Buteo 3 [1988]: 1-34. [In Slovak with English summary]

Danko Š 1991: Správa o činnosti Skupiny pre výskum a ochranu dravcov a sov v ČSFR za rok 1989 [Report on the Activity of the Group for Research and Protection of Birds of Prey and Owls in Czechoslovakia in 1989]. Buteo 4 [1989]: 1-28. [In Slovak with English summary]

Danko Š 1992a: Správa o činnosti Skupiny pre výskum a ochranu dravcov a sov v ČSFR za rok 1990 [Report on the Activity of the Group for Research and Protection of Birds of Prey and Owls in Czechoslovakia in 1990]. Buteo 5 [1990]: 1-30. [In Slovak with English summary]

Danko Š 1992b: Doterajšie poznatky z výskumu orla krikl'avého (Aquila pomarina) v Československu [The Present Knowledge from the Research of Lesser Spotted Eagle (Aquila pomarina) in Czechoslovakia]. Buteo 5[1990]: 37-48. [In Slovak with English summary]

Danko Š 1994a: Správa o činnosti Skupiny pre výskum a ochranu dravcov a sov v ČSFR za rok 1991 [Report on the Activity of the Group for Research and Protection of Birds of Prey and Owls in Czechoslovakia in 1991]. Buteo 6: 90-120. [In Slovak with English summary]

Danko Š 1994b: Správa o činnosti Skupiny pre výskum a ochranu dravcov a sov v ČSFR za rok 1992 [Report on the Activity of the Group for Research and Protection of Birds of Prey and Owls in Czechoslovakia in 1992]. Buteo 6: 121-151. [In Slovak with English summary]

Danko Š sine anno [1981]: Správa o činnosti Skupiny pre výskum dravého vtáctva a sov v ČSSR za rok 1980 [Report on the Activity of the Group for Research of Birds of Prey and Owls in Czechoslovakia in 1980]. Skupina pro výzkum dravých ptáků a sov, Zprávy 1/80: 3-12. [In Slovak]

Danko Š sine anno [1982]: Správa o činnosti Skupiny pre výskum a ochranu dravých vtákov a sov v ČSSR za rok 1981 [Report on the Activity of the Group for Research and Protection of Birds of Prey and Owls in Czechoslovakia in 1981]. Skupina pro výzkum dravých ptáků a sov, Zprávy 2/81: 1-13. [In Slovak]

Danko Š sine anno [1983]: Správa o činnosti Skupiny pre výskum a ochranu dravého vtáctva a sov v ČSSR za rok 1982 [Report on the Activity of the Group for Research and Protection of Birds of Prey and Owls in Czechoslovakia in 1982]. Skupina pro výzkum dravých ptáků a sov, Zprávy 3/82: 1-13. [In Slovak with English summary]

Danko Š sine anno [1984]: Správa o činnosti Skupiny pre výskum a ochranu dravého vtáctva a sov v ČSSR za rok 1983 [Report on the Activity of the Group for Research and Protection of Birds of Prey and Owls in Czechoslovakia in 1983]. Skupina pro výzkum dravých ptáků a sov, Zprávy 4/83: 1-15. [In Slovak with English summary]

Danko Š sine anno [1985]: Správa o činnosti Skupiny pre výskum a ochranu dravcov a sov v ČSSR za rok 1984 [Report on the Activity of the Group for Research and Protection of Birds of Prey and Owls in Czechoslovakia in 1984]. Skupina pro výzkum dravých ptáků a sov, Zprávy 5/84: 1-20. [In Slovak with English summary]

Danko Š, Chavko J \& Karaska D 1995a: Správa o činnosti Skupiny pre ochranu dravcov a sov SOS za rok 1993 [Report on the Activity of the Group on Protection of Birds of Prey and Owls of the Slovak Ornithological Society in 1993]. Buteo 7: 109-121. [In Slovak with English summary]

Danko Š, Chavko J \& Karaska D 1995b: Správa o činnosti Skupiny pre ochranu dravcov a sov SOS za rok 1994 [Report on the Activity of the Group on Protection of Birds of Prey and Owls of the Slovak Ornithological Society in 1994]. Buteo 7: 132-148. [In Slovak with English summary]

Danko Š, Karaska D \& Chavko J 2000: Správa o činnosti Skupiny pre ochranu dravcov a sov Slovenskej ornitologickej spoločnosti za rok 1995 [Report on the activity of the Group on Protection of Birds of Prey and Owls of the Slovak Ornithological Society in 1995]. Tichodroma 13: 227-250. [In Slovak with English summary]

Danko Š, Diviš T, Dvorská J, Dvorský M, Chavko J, 
Karaska D, Kloubec B, Kurka P, Matušík H, Peške L, Schröpfer L \& Vacík R 1994: Stav poznatkov o početnosti hniezdnych populácií dravcov (Falconiformes) a sov (Strigiformes) v Českej a Slovenskej republike $\mathrm{k}$ roku 1990 a ich populačný trend $\mathrm{v}$ rokoch 1970-1990. The state of knowledge of breeding numbers of birds of prey (Falconiformes) and owls (Strigiformes) in the Czech and Slovak republics as of 1990 and their population trends in 1970-1990. Buteo 6: 1-89.

Danko Š, Darolová A \& Krištín A 2002: Rozšírenie vtákov na Slovensku [Birds Distribution in Slovakia]. Veda, Bratislava, 688. [In Slovak with English summaries]

Danko Š \& Pčola Š 2008: Vtáctvo Vihorlatských vrchov a ich predhorí [Birds of the Vihorlat Mountains and their Foothills]. Správa CHKO Vihorlat Michalovce, 148. [In Slovak with English summary]

Danko Š et al. 2010: Vtáctvo Slanských vrchov a ich predhorí [Birds of the Slanské vrchy Mountains and their Foothills]. Slovenská ornitologická spoločnost'/BirdLife Slovensko Bratislava, 252. [In Slovak with English summary]

Databanka Fauny Slovenska [Databank of Slovak Fauna] Retrieved on April 1, 2014. http://dfs.fns.uniba.sk/mapy/komentar.htm,

Demko M, Krištín A \& Puchala P 2013: Červený zoznam vtákov Slovenska. Red list of birds in Slovakia. Tichodroma 25: 69-78 [In Slovak with English abstract]

Dravecký M 2000: Niekol'ko poznámok k výskytu orlov kriklavých (Aquila pomarina) v centrálnej časti Volovských vrchov [Some notes to occurrence of the Lesser Spotted Eagle (Aquila pomarina) in the central part of the Volovské vrchy Mts]. Natura Carpatica 41: 153-156. [In Slovak with English summary]

Dravecký M 2004a: Poznatky z monitoringu, početnosti a ochrany orla krikl'avého (Aquila pomarina) z východnej časti územia Slovenského krasu [Findings from monitoring, abundance and conservation of the Lesser Spotted Eagle (Aquila pomarina) from eastern part of the Slovak Karst], 145-155. In: Maníková M (ed), 30 rokov výskumu a ochrany prírody Slovenského krasu. Zborník referátov a prezentácí́ z konferencie konanej pri príležitosti 30 . výročia vyhlásenia CHKO Slovenský kras 19.-20. novembra 2003 v Rožňave. ŠOP SR, Správa NP Slovenský kras \& ZO SZOPK Makatanhan Oyate, Brzotín \& Moldava nad Bodvou, 186. [In Slovak with English abstract]

Dravecký M 2004b: Békászó sasok (Aquila pomarina) fészkelésének és a fészkelőhelyekre ható negatív tényezők monitoringja kelet Szlovákiában [Monitoring, breeding and impact of negative factors on breeding biotopes of the lesser spotted eagles (Aquila pomarina) in Eastern Slovakia], 25. In: Anonymus (ed), Absztrakt kötet MME VI. Tudományos Ülése, 2004. Október 29-31, Debrecen. MME HBCS, Debrecen, 116. [In Hungarian]

Dravecký M 2006: Orol krikl’avý (Aquila pomarina). Správa za rok 2005 [Lesser spotted eagle (Aquila pomarina). Report from 2005]. Dravce a sovy 2(2): 15. [In Slovak]

Dravecký M 2007: Orol krikl'avý (Aquila pomarina). Správa za rok 2006 [Lesser spotted eagle (Aquila pomarina). Report from 2006]. Dravce a sovy 3(1): 7. [In Slovak]

Dravecký M 2008: Orol krikl'avý (Aquila pomarina). Správa za rok 2007 [Lesser spotted eagle (Aquila pomarina). Report from 2007]. Dravce a sovy 4(1): 6. [In Slovak]

Dravecký M 2009: Orol krikl'avý (Aquila pomarina). Správa za rok 2008. [Lesser spotted eagle (Aquila pomarina). The Annual report 2008]. Dravce a sovy 5(1): 8. [In Slovak].

Dravecký M 2010: Orol krikl'avý (Aquila pomarina) [Lesser spotted eagle (Aquila pomarina)]. Dravce a sovy 6(1): 5. [In Slovak]

Dravecký M 2011: Orol krikl'avý (Aquila pomarina) [Lesser spotted eagle (Aquila pomarina)]. Dravce a sovy 7(1): 7. [In Slovak]

Dravecký M 2012: Orol kriklavý (Aquila pomarina) [Lesser spotted eagle (Aquila pomarina)]. Dravce a sovy 8(1): 4-5. [In Slovak]

Dravecký M 2013: Orol krikl’avý (Aquila pomarina) [Lesser spotted eagle (Aquila pomarina)]. Dravce a sovy 9(1): 4-5. [In Slovak]

Dravecký M, Danko Š, Hrtan E, Kicko J, Maderič B, Mihók J, Balla M, Bělka T \& Karaska D 2013: Colour ringing programme of the lesser spotted eagle (Aquila pomarina) population in Slovakia and its new results in the period 2009-2012. Slovak Raptor Journal 7, 17-36. DOI: 10.2478/srj-2013-0008.

Dravecký M, Danko Š \& Siryová S 2006: Orol krikl'avý. Lesser spotted eagle. Ochrana dravcov na Slovensku, Bratislava, 24. [In Slovak and English]

François J 2007: L'Aigle pomarin en Lorraine. Ciconia 31: 83-88. 
Hagemeijer EJM \& Blair MJ (eds) 1997: The EBCC Atlas of European breeding birds - their distribution and abundance. T and AD Poyser, London, 904.

Haraszthy L, Bagyura J \& Szitta T 1996: Zur biologie des schreiadlers Aquila pomarina in Ungarn, 305-312. In: Meyburg B-U \& Chancellor RD (eds), Eagle studies. World Working Group on Birds of Prey: Berlin, London \& Paris, 549.

Hintze J L 1997-2001: User's Guide - I, II, IV. NCSS Statistical System. Number Cruncher Statistical Systems, Kaysville, 3492.

Hora J \& Kaňuch P (eds) 1992: Významná ptačí území v Europě, Československo [Important Bird Areas in Europe, Czechoslovakia]. Československá sekce ICBP, Praha, 114. [In Czech]

Hudec K 1979: Červená listina ohrožených ptačích druhů v ČSSR [Red list of endangered bird species in Czechoslovakia], 35-39. In: Foukal J (ed), Právní normy $\mathrm{v}$ ochraně prrírody [Legal standards in nature conservation]. Praha. 325.[In Czech]

Jedlička L, Kocian L', Kadlečík J \& Feráková V 2007: Hodnotenie stavu ohrozenia taxónov fauny a flóry [Evaluation of the threat status of taxa of flora and fauna]. Štátna ochrana prírody, Banská Bystrica, Univerzita Komenského v Bratislave, Faunima, Bratislava, 138. [In Slovak]

Karaska D \& Danko Š 2002: Orol krikl'avý (Aquila pomarina) [Lesser Spotted Eagle], 195-197. In. Danko Š, Darolová A \& Krištín A (eds), Rozšírenie vtákov na Slovensku [Bird distribution in Slovakia]. Veda, Bratislava, 688. [In Slovak with English summary]

Karaska D 2013: Tridsat' rokov s orlom krikl'avým na Orave [Thirty years with lesser spotted eagle in Orava region]. Vtáky, 8 (1): 4-5. [In Slovak]

Karaska D \& Cichocki W 2014: Hniezdne rozšírenie vtáctva Oravy [Birds distribution of Orava region]. Slovenská ornitologická spoločnost'/BirdLife Slovensko, Bratislava, in prep. [In Slovak and Polish with English summary]

Kicko J 2006a: Niekol'ko výsledkov z monitorovania hniezdenia orla krikl'avého v NAPANT-e [Several results from monitoring of the Lesser Spotted Eagle during breeding in the Low Tatras National Park], 24. In: Stloukal E (ed), Zborník abstraktov z konferencie 12. Feriancove dni. Faunima, Bratislava, 61. [In Slovak]

Kicko J 2006b: Prvé výsledky sčítania orla krikl'avého (Aquila pomarina) na strednom a hornom Pohroní [The first results of the Lesser Spotted Eagle's
(Aquila pomarina) census in central and upper "Pohronie" region], 25-26. In: Kropil R (ed): Aplikovaná ornitológia 2005 a 2006. Zborník abstraktov zo 17. a 18. stredoslovenskej ornitologickej konferencie s medzinárodnou účast'ou konanej vo Zvolene 15.-16. 9. 2005 a 8.-9. 9. 2006. Technická univerzita Zvolen v spolupráci so ŠOP SR Banská Bystrica, Zvolen, 52. [In Slovak]

Korňan J, Maderič B \& Siryová S 2003: Program záchrany orla krikl'avého (Aquila pomarina Brehm, 1831) [Rescue Program for the lesser spotted eagle (Aquila pomarina Brehm, 1831)]. Štátna ochrana prírody Slovenskej republiky Banská Bystrica, Správa CHKO Kysuce, Čadca. 25. [In Slovak]

Krištín A, Danko S̆, Darolová A, Kocian L, Kropil R, Murin B, Stollmann A \& Urban P 1998: Červený zoznam a ekosozologický status vtákov (Aves) Slovenska [Red List and ekosozological status of birds (Aves) of Slovakia]. Ochrana prírody 16: 219-232. [In Slovak]

Krištín A 1998: Plazy a vtáky [Reptiles and Birds]: 89-92. In: Sláviková D \& Krajčovič, V (eds), Ochrana biodiverzity a obhospodarovanie trvalých trávnych porastov $\mathrm{CHKO}$ - BR Pol'ana 2 [Protection of biodiversity and maintenance of permanent grassland PLA - BR Pol'ana 2]. Vydalo IUCN, Svetová únia ochrany prírody, Slovensko, Bratislava, v rámci projektu Regionálneho európskeho programu IUCN so sídlom v Cambridge, Vel'ká Británia a Gland, Švajčiarsko, 205. [In Slovak]

Krištín A, Kocian L' \& Rác P 2001: Červený (ekosozologický) zoznam vtákov (Aves) Slovenska [Red (ekosozological) List of Birds (Aves) of Slovakia], 150-153. In: Baláž D, Marhold K \& Urban P (eds): Červený zoznam rastlín a živočíchov Slovenska [Red List of Plants and Animals of Slovakia], Ochrana prírody 20 (Suplement), 160 [In Slovak with English abstract]

Kroupová V 1980: Topografické podklady Databanky fauny Slovenska [Topographic data of Databank of Slovak Fauna]. Správy Slovenskej zoologickej spoločnosti SAV 7: 23-27. [In Slovak]

Krumenacker T 2012: Der Durchzug von Schreiadler Aquila pomarina, Wespenbussard Pernis apivorus, Kurzfangsperber Accipiter brevipes, Weißstorch Ciconia ciconia und Rosapelikan Pelecanus onocrotalusüber Nordisrael - eine Bilanz aus 30 Jahren. Limicola 26 (3): 161-237

Krumenacker T 2013: The migration of Lesser Spotted 
Eagle Aquila pomarina, European Honey Buzzard Pernis apivorus, Levant Sparrowhawk Accipiter brevipes and White Stork Ciconia ciconia over Northern Israel - a balance over 30 years of counts. Studia i Materiały CEPL w Rogowie. R. 15. Zeszyt 36 (3): 247-267.

Maderič B, Mikiara Š \& Pečeňák V 1995: Výskum populačnej hustoty dravcov $\mathrm{v}$ západnej časti okresu Humenné [Research into the population density of birds of prey in the western part of Humenné district (Eastern Slovakia)]. Buteo 7: 169-172. [In Slovak with English summary]

Maderič B 2005: Orol kriklavý (Aquila pomarina). Správa za rok 2004. [Lesser spotted eagle (Aquila pomarina). The Annual report 2004]. Dravce a sovy 1(1): 9. [In Slovak]

Mazúr E \& Lukniš M 1980: Geomorfologické jednotky Slovenska 1:500 000. [Geomorphological units of Slovakia 1:500 000], 54-55. In: Mazúr E (ed), Atlas SSR [Atlas of Slovakia]. SAV a SÚGK, Bratislava. 296. [In Slovak with English and Russian summary]

Meyburg B-U 1996: Der Schreiadler: Bestandssituation und derzeitiger Stand seiner Erforschung, 377-387. In: Meyburg B-U \& Chancellor RD (eds.), Eagle studies. World Working Group on Birds of Prey: Berlin, London \& Paris, 549.

Meyburg B-U, Haraszthy L, Strazds M \& Schäffer N (2001): European Union Species Action Plan for Lesser Spotted Eagle (Aquila pomarina), In: Schäffer N \& Gallo-Orsi U (eds), European Union action plans for eight priority bird species: Bittern (Botaurus stelaris), Ferruginous Duck (Aythya nyroca), Steller's Eider (Polysticta stelleri), Lammergeier (Gypaetus barbatus), Greater Spotted Eagle (Aquila clanga), Lesser Spotted Eagle (Aquila pomarina), Bonelli's Eagle (Hieraaetus fasciatus), Little Bustard (Tetrax tetrax). Office for Official Publications of the European Communities, Luxembourg, 247.

Meyburg B-U, Langgemach T, Graszynski K \& Böhner J 2004: The Situation of the Lesser Spotted Eagle Aquila pomarina in Germany: The need for an Action Plan and active conservation, 601-613. In: Chancellor RD \& Meyburg B-U (eds): Raptors Worldwide. Proceedings of the VI world conference on birds of prey and owls. Budapest, Hungary 18-23 May 2003. World Working Group on Birds of Prey and Owls \& MME/BirdLife Hungary, Berlin \& Budapest, 867.
Meyburg B-U, Graszynski K, Langgemach T, Sömmer P \& Bergmanis U 2008: Cainism, nestling management in Germany in 2004-2007 and satellite tracking of juveniles in the Lesser Spotted Eagle (Aquila pomarina). Slovak Raptor Journal 2: 53-72. DOI: 10.2478/v10262-012-0018-2.

Michelat D 2005 : Une nouvelle espèce nicheuse pour l'avifaune française: l'Aigle pomarin Aquila pomarina. Ornithos 12: 310-320.

Mošanský A 1972: Dravce (Falconiformes) východného Slovenska I. Supy, orly, myšiaky, jastraby a haje [Birds of prey (Falconiformes) of Eastern Slovakia. Vultures, buzzards, hawks and kites]. Zborník Východoslovenského Múzea, Zoológia - Botanika 11-12B[1970-1971]: 39-125. [In Slovak with German summary]

Mrlík V \& Danko Š 1989: Stavy hnízdících párů dravců v Československu (stav k roku 1988) [Numbers of breeding pairs of raptors in Czechoslovakia in 1988]. Buteo 2[1987]: 37-40. [In Czech with English summary]

Mrlík V \& Danko Š 1990: Počty hnízdících párů dravců v Československu (stav k roku 1988) [Numbers of breeding pairs of raptors in Czechoslovakia in 1988]. Sylvia 27: 71-78. [In Czech with English summary]

Murin B, Krištín A, Darolová A, Danko Š \& Kropil R 1994: Početnost' hniezdnych populácií vtákov na Slovensku [Breeding bird population sizes in Slovakia]. Sylvia 30(2): 97-105. [In Slovak with English abstract]

Polák P \& Saxa A (eds) 2005: Priaznivý stav biotopov a druhov európskeho významu [The favorable status of habitats and species of European importance]. ŠOP SR, Banská Bystrica, 736. [In Slovak]

Pongrácz Á, Szegedi Z, Kováts L, Szinai P \& Bank L 2012: Békászó sas állományadatok - 2010. Lesser spotted eagle population data 2010. Heliaca 8: 46-47. [In Hungarian with English summary]

Potočný R 1991: Početnost' a charakter výskytu orla krikl'avého (Aquila pomarina) v okrese Prešov v rokoch 1988-1990 [Abundance and distribution pattern of the Lesser Spotted Eagle (Aquila pomarina) in the Prešov district in 1988-1990]. Buteo 4[1989]: 73-78. [In Slovak with English summary]

Rybanič R, Šutiaková T \& Benko Š (eds) 2004: Významné vtáčie územia na Slovensku. Územia významné z pohl'adu Európskej únie. Important Bird Areas of European Union Importance in Slovakia. Spoločnost' pre ochranu vtáctva na Slovensku, 
Bratislava, 219. [In Slovak with English summary] Sedláček K, Donát P, Št’astný K, Randík A, Hudec K \& Varga J 1988: Červená kniha 1 - ohrožených a vzácných druhů rostlin a živočichů ČSSR. Ptáci. [Red Book 1 - endangered and rare species of flora and fauna of Czechoslovakia. Birds]. Státní zemědělské nakladatelství, Praha, 180. [In Czech with Russian, English and German summaries]

Szegedi Z, Szitta T, Kováts L \& Bank L 2010: Békászó sas (Aquila pomarina) állomány adatok - 2008. Data on breeding populations of Lesser-spotted eagle - 2008. Heliaca 6: 42-43. [In Hungarian with English summary]

Sládek J 1955: K ochrane orla krikl'avého (Aquila pomarina Brehm) na Slovensku [About conservation of the Lesser Spotted Eagle (Aquila pomarina Brehm) in Slovakia]. Ochrana Př́rody 10(6): 176-181. [In Slovak with Russian and German summaries]

Schäffer N \& Gallo-Orsi U 2001: European Union action plans for eight priority bird species: Bittern (Botaurus stelaris), Ferruginous Duck (Aythya nyroca), Steller's Eider (Polysticta stelleri), Lammergeier (Gypaetus barbatus), Greater Spotted Eagle (Aquila clanga), Lesser Spotted Eagle (Aquila pomarina), Bonelli's Eagle (Hieraaetus fasciatus), Little Bustard (Tetrax tetrax). Office for Official Publications of the European Communities, Luxembourg, 247.

Stloukal E 2001: Databanka Fauny Slovenska - stav a nové prírastky databáz v roku 2001 [Current status and new data in Databank of Slovak fauna in year 2001]. Folia faunistica slovaca 6: 145-168. [In Slovak with English abstract]

Stloukal E \& Grujbárová Z 2004. Databáza lokalít pre mapovanie fauny na území Slovenska [Database sites for mapping Fauna in Slovakia]. http://dfs.fns.uniba.sk/

ŠOP SR 2014: Natura 2000. Retrieved July 15, 2014, from http://www.sopsr.sk/natura/index1.php? $\mathrm{p}=4 \&$ lang $=\mathrm{sk} \& \mathrm{sec}=1 \& \mathrm{cpt}=1$.

Šotnár K 2006: Orol skalný (Aquila chrysaetos) a orol krikl'avý (Aquila pomarina) v Chránenej krajinnej oblasti Ponitrie [Golden Eagle (Aquila chrysaetos) and lesser spotted eagle (Aquila pomarina) in the Landscape protected area Ponitrie]. Rosalia (Nitra) 18: 217-224. [In Slovak with English abstract]

Šotnár K \& Topercer J 2009: Estimating density, population size and dynamics of Common Buzzard (Bu- teo buteo) in a West Carpathian region by a new method. Slovak Raptor Journal 3: 1-12. DOI:10.2478/v10262-012-0027-1.

Šrank V \& Slobodník V 1988: Príspevok ku skladbe vtáctva v širšom okolí Prievidze [Contribution to the species composition of birds in the surroundings Prievidza]. Horná Nitra 13: 119-159. [In Slovak]

Št’astný K, Randík A \& Hudec K 1987: Atlas hnízdního rozšíření ptáků v ČSSR 1973-1977 [Atlas of breeding birds in ČSSR in 1973/1977]. Academia, Praha, 483. [In Czech]

Št’astný K \& Bejček V 2003: Červený seznam ptáků České republiky [The Red List of birds of the Czech Republic], 95-121. In: Plesník J, Hanzal J \& Brejšková L (eds), Červený seznam ohrožených druhu České republiky. Obratlovci [Red List of Threatened Species in the Czech Republic. Vertebrates]. Prríroda 22, Praha. 184. [In Czech with English and German summaries]

Št’astný K, Bejček V \& Hudec K 2006: Atlas hnízdního rozšíření ptáků v České republice 2001-2003 [Atlas of breeding birds in ČSSR 2001-2003], Aventinum, Praha, 463. [In Czech with English summary]

Tucker GM \& Heath MF (1994): Birds in Europe: their conservation status. Cambridge, U. K.: BirdLife International (BirdLife Conservation Series no. 3), 600.

Voskár J 1976: Populačná hustota a ochrana dravých vtákov na východnom Slovensku od roku 1965 do roku 1973 [Population density and protection of raptors in eastern Slovakia in 1965-1973]. Polovnícky zborník 5-6: 368-397. [In Slovak with Russian, German and Hungarian summaries]

Voskár J 1977: Súčasné stavy, populačná hustota a ochrana dravých vtákov na východnom Slovensku [Current numbers, population density and protection of raptors in eastern Slovakia], 21-22. In: Randík A (ed), Falconiana I. Súbor referátov zo seminára "Súčasný stav rozšírenia a ochrany dravých vtákov v Československu", Nitra, 24.-25. septembra 1976 [Falconiana I. Proceedings from seminar "Current state of distribution and protection of raptors in Czechoslovakia ", Nitra, September 24-25, 1976]. Ústav experimentálnej fytopatológie a entomológie SAV, Sekcia ochrany fauny Slovenskej zoologickej spolocnosti SAV \& Sekcia ochrany vtáctva Československej ornitologickej spoločnosti, Bratislava, 107. [In Slovak and German] 


\section{Appendix 1.}

Abundance and density of the lesser spotted eagle breeding population according to administrative regions by 1997 (evaluated period: 1986-1996)

Početnost' a hustota hniezdnej populácie orla kriklavého na Slovensku podla správnych regiónov k roku 1997 (hodnotené obdobie rokov 1986-1996)

\begin{tabular}{|c|c|c|c|c|c|c|c|}
\hline \multirow{2}{*}{\multicolumn{2}{|c|}{ 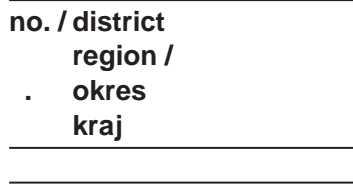 }} & \multirow{2}{*}{$\begin{array}{l}\text { area / } \\
\text { rozloha } \\
{\left[\mathrm{km}^{2}\right]} \\
\end{array}$} & \multirow{2}{*}{$\begin{array}{l}\text { confirmed } \\
\text { pairs / } \\
\text { zistené } \\
\text { páry } \\
(\mathrm{CP}) \\
\end{array}$} & \multirow{2}{*}{$\begin{array}{l}\text { probable } \\
\text { pairs / } \\
\text { predpokladané } \\
\text { páry } \\
(P P) \\
\end{array}$} & \multirow{2}{*}{$\begin{array}{l}\text { possible } \\
\text { pairs / } \\
\text { odhadované } \\
\text { páry } \\
(\mathrm{PoP}) \\
\end{array}$} & \multirow{2}{*}{\multicolumn{2}{|c|}{$\begin{array}{l}\text { density / } \\
\text { denzita } \\
{\left[p .100 \mathrm{~km}^{-2}\right]} \\
\end{array}$}} \\
\hline & & & & & & & \\
\hline 1. & Trebišov & 1322 & 4 & 3 & 4 & 11 & 0.83 \\
\hline 2. & Michalovce & 1310 & 20 & 3 & 2 & 25 & 1.91 \\
\hline 3. & Humenné & 1909 & 60 & 30 & 11 & 101 & 5.29 \\
\hline 4. & Vranov n. Topl'ou & 846 & 19 & 12 & 5 & 36 & 4.26 \\
\hline 5. & Svidník & 862 & 10 & 22 & 13 & 45 & 5.22 \\
\hline 6. & Bardejov & 1014 & 4 & 26 & 15 & 45 & 4.44 \\
\hline 7. & Stará L'ubovňa & 624 & 28 & 13 & 9 & 50 & 8.01 \\
\hline 8. & Prešov & 1418 & 25 & 11 & 0 & 36 & 2.54 \\
\hline 9. & Košice $(m+v)$ & 1777 & 31 & 7 & 6 & 44 & 2.48 \\
\hline 10. & Rožňava & 1621 & 6 & 18 & 7 & 31 & 1.91 \\
\hline 11. & Spišská N. Ves & 1529 & 13 & 2 & 10 & 25 & 1.64 \\
\hline 12. & Poprad & 1963 & 28 & 13 & 15 & 56 & 2.85 \\
\hline $\bar{\Sigma}$ & $\begin{array}{l}\text { Vých. Slovensko / } \\
\text { Eastern Slovakia }\end{array}$ & 16195 & 248 & 160 & 97 & 505 & 3.12 \\
\hline 13. & Dolný Kubín & 1660 & 41 & 67 & 9 & 117 & 7.05 \\
\hline & Liptovský Mikuláš & 1969 & 28 & 5 & 5 & 38 & 2.29 \\
\hline & Banská Bystrica & 2075 & 6 & 3 & 1 & 10 & 0.48 \\
\hline & Rimavská Sobota & 1823 & 3 & 2 & 8 & 13 & 0.71 \\
\hline 17. & Lučenec & 1304 & 0 & 3 & 5 & 8 & 0.61 \\
\hline & Vel'ký Krtíš & 848 & 0 & 5 & 1 & 6 & 0.70 \\
\hline & Zvolen & 1721 & 5 & 7 & 4 & 16 & 0.93 \\
\hline 20. & Žiar nad Hronom & 1264 & 2 & 4 & 0 & 6 & 0.47 \\
\hline 21. & Prievidza & 960 & 7 & 5 & 3 & 15 & 1.56 \\
\hline 22. & Martin & 1128 & 6 & 8 & 0 & 14 & 1.24 \\
\hline 23. & Žilina & 1097 & 4 & 3 & 0 & 7 & 0.64 \\
\hline 24. & Čadca & 934 & 0 & 0 & 0 & 0 & 0.00 \\
\hline 25. & Považská Bystrica & 1197 & 0 & 2 & 0 & 2 & 0.17 \\
\hline $\bar{\Sigma}$ & $\begin{array}{l}\text { Stredné Slovensko / } \\
\text { Central Slovakia }\end{array}$ & 17980 & 102 & 114 & 36 & 252 & 1.40 \\
\hline 26. & Trenčín & 1310 & 0 & 1 & 0 & 1 & 0.08 \\
\hline 27. & Topol'čany & 1361 & 1 & 0 & 0 & 1 & 0.07 \\
\hline & Nitra & 1443 & 0 & 0 & 0 & 0 & 0.00 \\
\hline & Levice & 1551 & 2 & 1 & 0 & 3 & 0.19 \\
\hline 30. - & -36. $(* 1)$ & 9196 & 0 & 0 & 0 & 0 & 0.00 \\
\hline $\bar{\Sigma}$ & $\begin{array}{l}\text { Západné Slovensko / } \\
\text { Western Slovakia }\end{array}$ & 14861 & 3 & 2 & 0 & 5 & 0.03 \\
\hline \multirow[t]{2}{*}{$\sum \Sigma$} & Slovensko / Slovakia & 49036 & 353 & 276 & 133 & 762 & \\
\hline & & & 629 & & 133 & 762 & \\
\hline
\end{tabular}

(*1) 30 Trnava, 31 Senica, 32 Bratislava, 33 Galanta, 34 Dunajská Streda, 35 Komárno, 36 Nové Zámky 
Slovak Raptor Journal 2015, 9: 7-44. DOI: 10.1515/srj-2015-0001.

(C) Raptor Protection of Slovakia (RPS)

\section{Appendix 2.}

Areas of administrative regions, elevation of hunting grounds, nesting sites and nests found of the lesser spotted eagle in Slovakia by 1997 (evaluated period: 1986-1996)

Rozlohy správnych regiónov, nadmorská výška lovísk, hniezdisk a zistených hniezd orla kriklavého na Slovensku k roku 1997 (hodnotené obdobie rokov 1986-1996)

\begin{tabular}{|c|c|c|c|c|c|c|c|c|}
\hline \multirow[t]{2}{*}{$\begin{array}{l}\text { no. / } \\
\text { č. }\end{array}$} & \multirow[t]{2}{*}{$\begin{array}{l}\text { district } \\
\text { region / } \\
\text { okres } \\
\text { kraj } \\
\end{array}$} & \multirow{2}{*}{$\begin{array}{l}\text { area / } \\
\text { rozloha } \\
\mathrm{km}^{2}\end{array}$} & \multirow{2}{*}{$\begin{array}{l}\text { region } \\
\text { min-max / } \\
\text { región } \\
\text { min-max } \\
\mathrm{m}\end{array}$} & \multirow{2}{*}{$\begin{array}{l}\begin{array}{l}\text { hunting } \\
\text { grounds / } \\
\text { loviská }\end{array} \\
\mathrm{m}\end{array}$} & \multirow{2}{*}{$\begin{array}{l}\text { nesting } \\
\text { sites / } \\
\text { hniezdiská }\end{array}$} & \multirow{2}{*}{$\begin{array}{l}\text { found } \\
\text { nests / } \\
\text { nájdené } \\
\text { hniezda } \\
\mathrm{m}\end{array}$} & $\begin{array}{l}\text { fores } \\
\text { lesy }\end{array}$ & region / \\
\hline & & & & & & & $\mathrm{km}^{2}$ & $\%$ \\
\hline 1. & Trebišov & 1322 & $96-850$ & $100-250$ & $100-850$ & $100-440$ & 161 & 12 \\
\hline 2. & Michalovce & 1310 & $97-1024$ & $100-500$ & $140-1024$ & $148-630$ & 292 & 22 \\
\hline 3. & Humenné & 1909 & $143-1221$ & $142-600$ & $200-1221$ & $160-700$ & 1109 & 58 \\
\hline 4. & Vranov n. Topl'ou & 846 & $110-1092$ & $110-600$ & 200-1092 & $210-750$ & 330 & 39 \\
\hline 5. & Svidník & 862 & $150-705$ & $150-600$ & $150-705$ & $350-500$ & 417 & 48 \\
\hline 6. & Bardejov & 1014 & $200-1157$ & $200-600$ & $300-1157$ & $300-700$ & 411 & 41 \\
\hline 7. & Stará L'ubovňa & 624 & $380-1150$ & $400-900$ & $400-1150$ & $450-750$ & 253 & 41 \\
\hline 8. & Prešov & 1418 & $200-1171$ & $200-900$ & $300-1171$ & $300-800$ & 518 & 37 \\
\hline 9. & Košice $(m+v)$ & 1777 & $160-1186$ & $160-500$ & $250-1186$ & $300-600$ & 720 & 41 \\
\hline 10. & Rožňava & 1621 & $200-1476$ & $200-700$ & $300-1476$ & $400-750$ & 1115 & 63 \\
\hline 11. & Spišská N. Ves & 1529 & $350-1322$ & $350-900$ & $450-1322$ & $500-700$ & 882 & 58 \\
\hline 12. & Poprad & 1963 & $450-2655$ & $500-750$ & $650-1000$ & $670-950$ & 1226 & 62 \\
\hline$\sum$ & $\begin{array}{l}\text { Vých. Slovensko / } \\
\text { Eastern Slovakia }\end{array}$ & 16195 & $96-2655$ & $100-900$ & $100-1476$ & $100-950$ & 7335 & 45 \\
\hline 13. & Dolný Kubín & 1660 & $427-2178$ & $430-1000$ & $500-1725$ & $580-840$ & 738 & 44 \\
\hline 14. & Liptovský Mikuláš & 1969 & $430-2248$ & $470-1000$ & $450-1600$ & $650-900$ & 1203 & 61 \\
\hline 15. & Banská Bystrica & 2075 & $300-2043$ & $300-900$ & $450-1100$ & - & 1322 & 64 \\
\hline 16. & Rimavská Sobota & 1823 & $200-1338$ & $200-700$ & $300-1338$ & - & 709 & 39 \\
\hline 17. & Lučenec & 1304 & $200-1111$ & $250-900$ & $250-1111$ & - & 567 & 44 \\
\hline 18. & Vel'ký Krtíš & 848 & $135-643$ & $250-400$ & $300-557$ & - & 257 & 30 \\
\hline 19. & Zvolen & 1721 & $140-1458$ & $400-700$ & $450-1458$ & $440-650$ & 722 & 42 \\
\hline 20. & Žiar nad Hronom & 1264 & $250-1265$ & $250-700$ & $400-1265$ & $350-800$ & 731 & 58 \\
\hline 21. & Prievidza & 960 & $181-1351$ & $200-500$ & $300-1351$ & $300-780$ & 523 & 54 \\
\hline 22. & Martin & 1128 & $380-1709$ & $400-800$ & $450-1709$ & $600-780$ & 639 & 57 \\
\hline 23. & Žilina & 1097 & $250-1709$ & $250-800$ & $400-1709$ & $450-500$ & 601 & 55 \\
\hline 24. & Čadca & 934 & $350-1236$ & - & - & - & 545 & 58 \\
\hline 25. & Považská Bystrica & 1197 & 224-1213 & $224-650$ & $500-1200$ & - & 672 & 56 \\
\hline$\sum$ & $\begin{array}{l}\text { Stredné Slovensko / } \\
\text { Central Slovakia }\end{array}$ & 17981 & $135-2248$ & $200-1000$ & $250-1725$ & $300-900$ & 9229 & 51 \\
\hline 26. & Trenčín & 1310 & $170-1042$ & $200-400$ & $250-1042$ & - & 538 & 41 \\
\hline 27. & Topol'čany & 1361 & $190-1010$ & $200-450$ & $200-1010$ & 400 & 542 & 40 \\
\hline 28. & Nitra & 1443 & $120-829$ & - & - & - & 300 & 21 \\
\hline 29. & Levice & 1551 & $150-757$ & $200-400$ & $200-757$ & $400-500$ & 290 & 19 \\
\hline $30 .-$ & 36. $(* 1)$ & 9196 & $107-768$ & - & - & - & 1681 & 18 \\
\hline$\sum$ & $\begin{array}{l}\text { Západné Slovensko / } \\
\text { Western Slovakia }\end{array}$ & 14860 & 107-1042 & $200-450$ & 200-1042 & $400-500$ & 3351 & 23 \\
\hline$\sum \sum$ & Slovensko / Slovakia & 49036 & $96-2655$ & $100-1000$ & $100-1725$ & $100-950$ & 19915 & 4 \\
\hline
\end{tabular}

(*1) 30 Trnava, 31 Senica, 32 Bratislava, 33 Galanta, 34 Dunajská Streda, 35 Komárno, 36 Nové Zámky 


\section{Appendix 3.}

Abundance and density of confirmed and probable pairs of the lesser spotted eagle in the orographic units of Slovakia by 1997 in descending arrangements according to abundances (evaluated period: 1986-1996)

Početnost' a hustota zistených a predpokladaných párov orla kriklavého v orografických celkoch Slovenska k roku 1997 v zostupnom usporiadaní podla početností (hodnotené obdobie rokov 1986-1996)

\begin{tabular}{|c|c|c|c|c|c|c|c|}
\hline$\overline{\text { no. I }}$ & $\begin{array}{l}\text { orographic unit / } \\
\text { orografický celok }\end{array}$ & $\begin{array}{l}\text { code / } \\
\text { kód }\end{array}$ & $\begin{array}{l}\text { confirmed } \\
\text { pairs / } \\
\text { zistené } \\
\text { páry }\end{array}$ & $\begin{array}{l}\text { probable } \\
\text { pairs / } \\
\text { predpoklad. } \\
\text { páry }\end{array}$ & $\sum$ & $\begin{array}{l}\text { area / } \\
\text { rozloha }\end{array}$ & $\begin{array}{l}\text { density / } \\
\text { denzita }\end{array}$ \\
\hline & (OrU) & & $(\mathrm{CP})$ & (PP) & (CP \& PP) & {$\left[\mathrm{km}^{2}\right]$} & [p.100 km-2] \\
\hline$\overline{1 .}$ & Laborecká vrchovina Upland & 750 & 36 & 24 & 60 & 1163.17 & 5.15 \\
\hline 2. & Ondavská vrchovina Upland & 740 & 20 & 40 & 60 & 1847.17 & 3.25 \\
\hline 3. & Slanské vrchy Mts & 440 & 27 & 7 & 34 & 534.25 & 6.36 \\
\hline 4. & Oravská vrchovina Upland & 590 & 16 & 14 & 30 & 279.50 & 10.73 \\
\hline 5. & Vihorlatské vrchy Mts & 710 & 20 & 4 & 24 & 360.18 & 6.66 \\
\hline 6. & Beskydské predhorie Mts & 760 & 17 & 6 & 23 & 636.64 & 3.61 \\
\hline 7. & Skorušinské vrchy Mts & 640 & 5 & 15 & 20 & 193.97 & 10.31 \\
\hline 8. & Oravská kotlina Basin & 630 & 6 & 12 & 18 & 229.02 & 7.86 \\
\hline 9. & Podbeskydská vrchovina Upland & 570 & 5 & 13 & 18 & 247.84 & 7.26 \\
\hline 10. & Spišská Magura Mts & 660 & 11 & 7 & 18 & 340.16 & 5.29 \\
\hline 11. & Bukovské vrchy Mts & 720 & 12 & 5 & 17 & 392.63 & 4.33 \\
\hline 12. & Popradská kotlina Basin & 252 & 11 & 5 & 16 & 570.19 & 2.81 \\
\hline 13. & Spišsko-šarišské medzihorie Mts & 690 & 13 & 2 & 15 & 521.34 & 2.88 \\
\hline 14. & L'ubovnianska vrch. Upland (west / záp.) & 610 & 6 & 8 & 14 & 161.91 & 8.65 \\
\hline 15. & Volovské vrchy Mts & 070 & 11 & 3 & 14 & 1349.61 & 1.04 \\
\hline 16. & Kozie chrbty Mts & 200 & 10 & 2 & 12 & 172.38 & 6.96 \\
\hline 17. & Levočské vrchy Mts & 670 & 11 & 1 & 12 & 622.45 & 1.93 \\
\hline 18. & Liptovská kotlina Basin & 251 & 10 & 2 & 12 & 650.42 & 1.85 \\
\hline 19. & Čergov Mts & 620 & 0 & 11 & 11 & 302.31 & 3.64 \\
\hline 20. & Strážovské vrchy Mts & 120 & 5 & 5 & 10 & 1144.94 & 0.87 \\
\hline 21. & Podbeskydská brázda Furrow & 560 & 2 & 7 & 9 & 135.21 & 6.66 \\
\hline 22. & Slovenský kras Mts & 060 & 3 & 6 & 9 & 483.12 & 1.86 \\
\hline 23. & Ďumbierske Tatry Mts & 190 & 8 & 0 & 8 & 673.07 & 1.19 \\
\hline 24. & Šarišská vrchovina Upland & 700 & 5 & 2 & 7 & 277.68 & 2.52 \\
\hline 25. & Hornádska kotlina Basin & 260 & 5 & 2 & 7 & 485.71 & 1.44 \\
\hline 26. & Východoslovenská pahorkatina Hills & 810 & 6 & 1 & 7 & 728.96 & 0.96 \\
\hline 27. & Stiavnicke vrchy Mts & 300 & 3 & 4 & 7 & 852.76 & 0.82 \\
\hline 28. & Košická kotlina Basin & 400 & 6 & 1 & 7 & 1161.72 & 0.60 \\
\hline 29. & Žiar Mts & 130 & 5 & 1 & 6 & 147.63 & 4.06 \\
\hline 30. & Vtáčnik Mts & 280 & 3 & 3 & 6 & 359.23 & 1.67 \\
\hline 31. & Malá Fatra Mts & 140 & 3 & 3 & 6 & 547.72 & 1.10 \\
\hline 32. & Vel'ká Fatra Mts & 150 & 3 & 3 & 6 & 775.01 & 0.77 \\
\hline 33. & Revúcka vrchovina Upland & 040 & 1 & 5 & 6 & 965.74 & 0.62 \\
\hline 34. & Slovenský raj Mts & 022 & 4 & 1 & 5 & 188.63 & 2.65 \\
\hline 35. & Čierna hora Mts & 080 & 4 & 1 & 5 & 249.19 & 2.01 \\
\hline 36. & Král'ovohol'ské Tatry Mts & 190 & 3 & 2 & 5 & 583.52 & 0.86 \\
\hline 37. & Krupinská planina Plateau & 350 & 0 & 5 & 5 & 858.37 & 0.58 \\
\hline 38. & Pieniny Mts & 600 & 4 & 0 & 4 & 53.00 & 7.55 \\
\hline 39. & Busov Mts & 730 & 1 & 3 & 4 & 105.12 & 3.81 \\
\hline 40. & Bachureň Mts & 680 & 3 & 1 & 4 & 126.13 & 3.17 \\
\hline 41. & Oravské Beskydy Mts & 550 & 0 & 4 & 4 & 131.61 & 3.04 \\
\hline 42. & Západné Tatry Mts & 181 & 0 & 4 & 4 & 306.20 & 1.30 \\
\hline 43. & Horehronské podolie Basin & 270 & 1 & 3 & 4 & 318.17 & 1.26 \\
\hline 44. & Kremnické vrchy Mts & 310 & 1 & 3 & 4 & 487.83 & 0.82 \\
\hline 45. & Podtatranská brázda Furrow (west / záp.) & 650 & 0 & 3 & 3 & 67.21 & 4.46 \\
\hline 46. & Oravská Magura Mts & 580 & 2 & 1 & 3 & 173.55 & 1.73 \\
\hline 47. & Stolické vrchy Mts & 030 & 2 & 1 & 3 & 608.35 & 0.49 \\
\hline 48. & Zvolenská kotlina Basin & 360 & 0 & 3 & 3 & 621.83 & 0.48 \\
\hline 49. & Veporské vrchy Mts & 010 & 2 & 1 & 3 & 856.50 & 0.35 \\
\hline
\end{tabular}


Slovak Raptor Journal 2015, 9: 7-44. DOI: 10.1515/srj-2015-0001.

(C) Raptor Protection of Slovakia (RPS)

\section{Appendix 3.}

Continuation

Pokračovanie

\begin{tabular}{|c|c|c|c|c|c|c|c|}
\hline 50. & Chočské vrchy Mts & 170 & 2 & 0 & 2 & 115.90 & 1.73 \\
\hline 51. & Pol'ana Mts & 320 & 1 & 1 & 2 & 180.05 & 1.11 \\
\hline 52. & Javorie Mts & 340 & 2 & 0 & 2 & 228.92 & 0.87 \\
\hline 53. & Žilinská kotlina Basin & 220 & 2 & 0 & 2 & 269.75 & 0.74 \\
\hline 54. & Hornonitrianska kotlina Basin & 230 & 1 & 1 & 2 & 425.94 & 0.47 \\
\hline 55. & Rimavská kotlina Basin & 393 & 0 & 2 & 2 & 823.34 & 0.24 \\
\hline 56. & Východoslovenská rovina Plain & 820 & 1 & 1 & 2 & 1697.52 & 0.12 \\
\hline 57. & L'ubovnianska vrc Upland (east / vých.) & 610 & 0 & 1 & 1 & 42.78 & 2.34 \\
\hline 58. & Rožňavská kotlina Basin & 050 & 0 & 1 & 1 & 68.35 & 1.46 \\
\hline 59. & Branisko Mts & 210 & 0 & 1 & 1 & 82.74 & 1.21 \\
\hline 60. & Zemplínske vrchy Mts & 450 & 0 & 1 & 1 & 100.38 & 1.00 \\
\hline 61. & Muránska planina Plateau & 021 & 1 & 0 & 1 & 161.78 & 0.62 \\
\hline 62. & Starohorské vrchy Mts & 160 & 0 & 1 & 1 & 179.25 & 0.56 \\
\hline 63. & Turčianska kotlina Basin & 240 & 0 & 1 & 1 & 417.83 & 0.24 \\
\hline 64. & Považský Inovec Mts & 100 & 1 & 0 & 1 & 463.60 & 0.22 \\
\hline 65. & Ipel'ská kotlina Basin & 391 & 0 & 1 & 1 & 567.75 & 0.17 \\
\hline 66. & Biele Karpaty Mts & 460 & 0 & 1 & 1 & 656.18 & 0.15 \\
\hline 67. & Ipel'ská pahorkatina Hills & 805 & 0 & 1 & 1 & 971.69 & 0.10 \\
\hline 68. & Jablunkovské medzihorie Mts & 520 & 0 & 0 & 0 & 61.24 & 0.00 \\
\hline 69. & Moravsko-sliezske Beskydy Mts & 500 & 0 & 0 & 0 & 21.94 & 0.00 \\
\hline 70. & Turzovská vrchovina Upland & 510 & 0 & 0 & 0 & 222.07 & 0.00 \\
\hline 71. & Kysucké Beskydy Mts & 530 & 0 & 0 & 0 & 156.40 & 0.00 \\
\hline 72. & Javorníky Mts & 470 & 0 & 0 & 0 & 885.30 & 0.00 \\
\hline 73. & Kysucká vrchovina Upland & 540 & 0 & 0 & 0 & 395.71 & 0.00 \\
\hline 74. & Podtatranská brázda Furrow (east / vých.) & 650 & 0 & 0 & 0 & 26.02 & 0.00 \\
\hline 75. & Považské podolie Basin & 490 & 0 & 0 & 0 & 557.29 & 0.00 \\
\hline 76. & Belianske Tatry Mts & 183 & 0 & 0 & 0 & 68.45 & 0.00 \\
\hline 77. & Vysoké Tatry Mts & 182 & 0 & 0 & 0 & 175.94 & 0.00 \\
\hline 78. & Dolnomoravský úval Dale & 900 & 0 & 0 & 0 & 59.91 & 0.00 \\
\hline 79. & Chvojnická pahorkatina Hills & 780 & 0 & 0 & 0 & 369.89 & 0.00 \\
\hline 80. & Borská nížina Lowlands & 770 & 0 & 0 & 0 & 1157.90 & 0.00 \\
\hline 81. & Nitrianska pahorkatina Hills & 802 & 0 & 0 & 0 & 1905.39 & 0.00 \\
\hline 82. & Myjavská pahorkatina Hills & 480 & 0 & 0 & 0 & 369.56 & 0.00 \\
\hline 83. & Trnavská pahorkatina Hills & 801 & 0 & 0 & 0 & 1327.83 & 0.00 \\
\hline 84. & Malé Karpaty Mts & 090 & 0 & 0 & 0 & 826.82 & 0.00 \\
\hline 85. & Dolnomoravský úval Dale & 900 & 0 & 0 & 0 & 19.93 & 0.00 \\
\hline 86. & Žiarska kotlina & 380 & 0 & 0 & 0 & 138.80 & 0.00 \\
\hline 87. & Tribeč Mts & 110 & 0 & 0 & 0 & 487.62 & 0.00 \\
\hline 88. & Pliešovská kotlina Basin & 370 & 0 & 0 & 0 & 108.08 & 0.00 \\
\hline 89. & Bodvianska pahorkatina Hills (east / vých.) & 410 & 0 & 0 & 0 & 39.83 & 0.00 \\
\hline 90. & Bodvianska pahorkatina Hills (west / záp.) & 410 & 0 & 0 & 0 & 98.53 & 0.00 \\
\hline 91. & Pohronský Inovec Mts & 290 & 0 & 0 & 0 & 141.90 & 0.00 \\
\hline 92. & Ostrôžky Mts & 330 & 0 & 0 & 0 & 254.71 & 0.00 \\
\hline 93. & Žitavská pahorkatina Hills & 803 & 0 & 0 & 0 & 447.22 & 0.00 \\
\hline 94. & Lučenecká kotlina Basin & 392 & 0 & 0 & 0 & 428.20 & 0.00 \\
\hline 95. & Hronská pahorkatina Hills & 804 & 0 & 0 & 0 & 1766.61 & 0.00 \\
\hline 96. & Cerová vrchovina Upland & 430 & 0 & 0 & 0 & 494.56 & 0.00 \\
\hline 97. & Podunajská rovina Plain & 790 & 0 & 0 & 0 & 3492.44 & 0.00 \\
\hline 98. & Burda Mts & 420 & 0 & 0 & 0 & 26.24 & 0.00 \\
\hline
\end{tabular}




\section{Appendix 4.}

Abundance and density of confirmed and probable pairs of the lesser spotted eagle in the orographic units of Slovakia by 1997 in descending arrangements according to densities (evaluated period: 1986-1996)

Početnost' a hustota zistených a predpokladaných párov orla kriklavého v orografických celkoch Slovenska k roku 1997 v zostupnom usporiadaní podl'a hustôt (hodnotené obdobie rokov 1986-1996)

\begin{tabular}{|c|c|c|c|c|c|c|c|}
\hline no. & orografický celok & $\begin{array}{l}\text { code / } \\
\text { kód }\end{array}$ & $\begin{array}{l}\text { confirmed } \\
\text { pairs / } \\
\text { zistené } \\
\text { páry }\end{array}$ & $\begin{array}{l}\text { probable } \\
\text { pairs / } \\
\text { predpokladané } \\
\text { páry }\end{array}$ & $\Sigma$ & $\begin{array}{l}\text { area / } \\
\text { rozloha }\end{array}$ & $\begin{array}{l}\text { density / } \\
\text { denzita }\end{array}$ \\
\hline & (OrU) & & $(\mathrm{CP})$ & $(\mathrm{PP})$ & (CP \& PP) & {$\left[\mathrm{km}^{2}\right]$} & [p.100 km-2] \\
\hline 1. & Oravská vrchovina Upland & 590 & 16 & 14 & 30 & 279.50 & 10.73 \\
\hline 2. & Skorušinské vrchy Mts & 640 & 5 & 15 & 20 & 193.97 & 10.31 \\
\hline 3. & L’ubovnianska vrch. Upland (west / záp.) & 610 & 6 & 8 & 14 & 161.91 & 8.65 \\
\hline 4. & Oravská kotlina Basin & 630 & 6 & 12 & 18 & 229.02 & 7.86 \\
\hline 5. & Pieniny Mts & 600 & 4 & 0 & 4 & 53.00 & 7.55 \\
\hline 6. & Podbeskydská vrchovina Upland & 570 & 5 & 13 & 18 & 247.84 & 7.26 \\
\hline 7. & Kozie chrbty Mts & 200 & 10 & 2 & 12 & 172.38 & 6.96 \\
\hline 8. & Vihorlatské vrchy Mts & 710 & 20 & 4 & 24 & 360.18 & 6.66 \\
\hline 9. & Podbeskydská brázda Furrow & 560 & 2 & 7 & 9 & 135.21 & 6.66 \\
\hline 10. & Slanské vrchy Mts & 440 & 27 & 7 & 34 & 534.25 & 6.36 \\
\hline 11. & Spišská Magura Mts & 660 & 11 & 7 & 18 & 340.16 & 5.29 \\
\hline 12. & Laborecká vrchovina Upland & 750 & 36 & 24 & 60 & 1163.17 & 5.15 \\
\hline 13. & Podtatranská brázda Furrow (west / záp.) & 650 & 0 & 3 & 3 & 67.21 & 4.46 \\
\hline 14. & Bukovské vrchy Mts & 720 & 12 & 5 & 17 & 392.63 & 4.33 \\
\hline 15. & Žiar Mts & 130 & 5 & 1 & 6 & 147.63 & 4.06 \\
\hline 16. & Busov Mts & 730 & 1 & 3 & 4 & 105.12 & 3.81 \\
\hline 17. & Čergov Mts & 620 & 0 & 11 & 11 & 302.31 & 3.64 \\
\hline 18. & Beskydské predhorie Mts & 760 & 17 & 6 & 23 & 636.64 & 3.61 \\
\hline 19. & Ondavská vrchovina Upland & 740 & 20 & 40 & 60 & 1847.17 & 3.25 \\
\hline 20. & Bachureň Mts & 680 & 3 & 1 & 4 & 126.13 & 3.17 \\
\hline 21. & Oravské Beskydy Mts & 550 & 0 & 4 & 4 & 131.61 & 3.04 \\
\hline 22. & Spišsko-šarišské medzihorie Mts & 690 & 13 & 2 & 15 & 521.34 & 2.88 \\
\hline 23. & Popradská kotlina Basin & 252 & 11 & 5 & 16 & 570.19 & 2.81 \\
\hline 24. & Slovenský raj Mts & 022 & 4 & 1 & 5 & 188.63 & 2.65 \\
\hline 25. & Šarišská vrchovina Upland & 700 & 5 & 2 & 7 & 277.68 & 2.52 \\
\hline 26. & L’ubovnianska vrch. Upland (east / vých.) & 610 & 0 & 1 & 1 & 42.78 & 2.34 \\
\hline 27. & Čierna hora Mts & 080 & 4 & 1 & 5 & 249.19 & 2.01 \\
\hline 28. & Levočské vrchy Mts & 670 & 11 & 1 & 12 & 622.45 & 1.93 \\
\hline 29. & Slovenský kras Mts & 060 & 3 & 6 & 9 & 483.12 & 1.86 \\
\hline 30. & Liptovská kotlina Basin & 251 & 10 & 2 & 12 & 650.42 & 1.85 \\
\hline 31. & Oravská Magura Mts & 580 & 2 & 1 & 3 & 173.55 & 1.73 \\
\hline 32. & Chočské vrchy Mts & 170 & 2 & 0 & 2 & 115.90 & 1.73 \\
\hline 33. & Vtáčnik Mts & 280 & 3 & 3 & 6 & 359.23 & 1.67 \\
\hline 34. & Rožňavská kotlina Basin & 050 & 0 & 1 & 1 & 68.35 & 1.46 \\
\hline 35. & Hornádska kotlina Basin & 260 & 5 & 2 & 7 & 485.71 & 1.44 \\
\hline 36. & Západné Tatry Mts & 181 & 0 & 4 & 4 & 306.20 & 1.30 \\
\hline 37. & Horehronské podolie Basin & 270 & 1 & 3 & 4 & 318.17 & 1.26 \\
\hline 38. & Branisko Mts & 210 & 0 & 1 & 1 & 82.74 & 1.21 \\
\hline 39. & Ďumbierske Tatry Mts & 190 & 8 & 0 & 8 & 673.07 & 1.19 \\
\hline 40. & Pol'ana Mts & 320 & 1 & 1 & 2 & 180.05 & 1.11 \\
\hline 41. & Malá Fatra Mts & 140 & 3 & 3 & 6 & 547.72 & 1.10 \\
\hline 42. & Volovské vrchy Mts & 070 & 11 & 3 & 14 & 1349.61 & 1.04 \\
\hline 43. & Zemplínske vrchy Mts & 450 & 0 & 1 & 1 & 100.38 & 1.00 \\
\hline 44. & Východoslovenská pahorkatina Hills & 810 & 6 & 1 & 7 & 728.96 & 0.96 \\
\hline 45. & Strážovské vrchy Mts & 120 & 5 & 5 & 10 & 1144.94 & 0.87 \\
\hline 46. & Javorie Mts & 340 & 2 & 0 & 2 & 228.92 & 0.87 \\
\hline 47. & Král'ovohol'ské Tatry Mts & 190 & 3 & 2 & 5 & 583.52 & 0.86 \\
\hline 48. & Štiavnické vrchy Mts & 300 & 3 & 4 & 7 & 852.76 & 0.82 \\
\hline 49. & Kremnické vrchy Mts & 310 & 1 & 3 & 4 & 487.83 & 0.82 \\
\hline
\end{tabular}


Slovak Raptor Journal 2015, 9: 7-44. DOI: 10.1515/srj-2015-0001.

(C) Raptor Protection of Slovakia (RPS)

\section{Appendix 4.}

Continuation

Pokračovanie

\begin{tabular}{|c|c|c|c|c|c|c|c|}
\hline$\overline{50 .}$ & Vel'ká Fatra Mts & 150 & 3 & 3 & 6 & 775.01 & 0.77 \\
\hline 51. & Žilinská kotlina Basin & 220 & 2 & 0 & 2 & 269.75 & 0.74 \\
\hline 52. & Revúcka vrchovina Upland & 040 & 1 & 5 & 6 & 965.74 & 0.62 \\
\hline 53. & Muránska planina Plateau & 021 & 1 & 0 & 1 & 161.78 & 0.62 \\
\hline 54. & Košická kotlina Basin & 400 & 6 & 1 & 7 & 1161.72 & 0.60 \\
\hline 55. & Krupinská planina Plateau & 350 & 0 & 5 & 5 & 858.37 & 0.58 \\
\hline 56. & Starohorské vrchy Mts & 160 & 0 & 1 & 1 & 179.25 & 0.56 \\
\hline 57. & Stolické vrchy Mts & 030 & 2 & 1 & 3 & 608.35 & 0.49 \\
\hline 58. & Zvolenská kotlina Basin & 360 & 0 & 3 & 3 & 621.83 & 0.48 \\
\hline 59. & Hornonitrianska kotlina Basin & 230 & 1 & 1 & 2 & 425.94 & 0.47 \\
\hline 60. & Veporské vrchy Mts & 010 & 2 & 1 & 3 & 856.50 & 0.35 \\
\hline 61. & Rimavská kotlina Basin & 393 & 0 & 2 & 2 & 823.34 & 0.24 \\
\hline 62. & Turčianska kotlina Basin & 240 & 0 & 1 & 1 & 417.83 & 0.24 \\
\hline 63. & Považský Inovec Mts & 100 & 1 & 0 & 1 & 463.60 & 0.22 \\
\hline 64. & Ipel'ská kotlina Basin & 391 & 0 & 1 & 1 & 567.75 & 0.17 \\
\hline 65. & Biele Karpaty Mts & 460 & 0 & 1 & 1 & 656.18 & 0.15 \\
\hline 66. & Východoslovenská rovina Plain & 820 & 1 & 1 & 2 & 1697.52 & 0.12 \\
\hline 67. & Ipel'ská pahorkatina Hills & 805 & 0 & 1 & 1 & 971.69 & 0.10 \\
\hline 68. & Jablunkovské medzihorie Mts & 520 & 0 & 0 & 0 & 61.24 & 0.00 \\
\hline 69. & Moravsko-sliezske Beskydy Mts & 500 & 0 & 0 & 0 & 21.94 & 0.00 \\
\hline 70. & Turzovská vrchovina Upland & 510 & 0 & 0 & 0 & 222.07 & 0.00 \\
\hline 71. & Kysucké Beskydy Mts & 530 & 0 & 0 & 0 & 156.40 & 0.00 \\
\hline 72. & Javorníky Mts & 470 & 0 & 0 & 0 & 885.30 & 0.00 \\
\hline 73. & Kysucká vrchovina Upland & 540 & 0 & 0 & 0 & 395.71 & 0.00 \\
\hline 74. & Podtatranská brázda Furrow (east / vých.) & 650 & 0 & 0 & 0 & 26.02 & 0.00 \\
\hline 75. & Považské podolie Basin & 490 & 0 & 0 & 0 & 557.29 & 0.00 \\
\hline 76. & Belianske Tatry Mts & 183 & 0 & 0 & 0 & 68.45 & 0.00 \\
\hline 77. & Vysoké Tatry Mts & 182 & 0 & 0 & 0 & 175.94 & 0.00 \\
\hline 78. & Dolnomoravský úval Dale & 900 & 0 & 0 & 0 & 59.91 & 0.00 \\
\hline 79. & Chvojnická pahorkatina Hills & 780 & 0 & 0 & 0 & 369.89 & 0.00 \\
\hline 80. & Borská nížina Lowlands & 770 & 0 & 0 & 0 & 1157.90 & 0.00 \\
\hline 81. & Nitrianska pahorkatina Hills & 802 & 0 & 0 & 0 & 1905.39 & 0.00 \\
\hline 82. & Myjavská pahorkatina Hills & 480 & 0 & 0 & 0 & 369.56 & 0.00 \\
\hline 83. & Trnavská pahorkatina Hills & 801 & 0 & 0 & 0 & 1327.83 & 0.00 \\
\hline 84. & Malé Karpaty Mts & 090 & 0 & 0 & 0 & 826.82 & 0.00 \\
\hline 85. & Dolnomoravský úval Dale & 900 & 0 & 0 & 0 & 19.93 & 0.00 \\
\hline 86. & Žiarska kotlina Basin & 380 & 0 & 0 & 0 & 138.80 & 0.00 \\
\hline 87. & Tribeč Mts & 110 & 0 & 0 & 0 & 487.62 & 0.00 \\
\hline 88. & Pliešovská kotlina Basin & 370 & 0 & 0 & 0 & 108.08 & 0.00 \\
\hline 89. & Bodvianska pahorkatina Hills (east / vých.) & 410 & 0 & 0 & 0 & 39.83 & 0.00 \\
\hline 90. & Bodvianska pahorkatina Hills (west / záp.) & 410 & 0 & 0 & 0 & 98.53 & 0.00 \\
\hline 91. & Pohronský Inovec Mts & 290 & 0 & 0 & 0 & 141.90 & 0.00 \\
\hline 92. & Ostrôžky Mts & 330 & 0 & 0 & 0 & 254.71 & 0.00 \\
\hline 93. & Žitavská pahorkatina Hills & 803 & 0 & 0 & 0 & 447.22 & 0.00 \\
\hline 94. & Lučenecká kotlina Basin & 392 & 0 & 0 & 0 & 428.20 & 0.00 \\
\hline 95. & Hronská pahorkatina Hills & 804 & 0 & 0 & 0 & 1766.61 & 0.00 \\
\hline 96. & Cerová vrchovina Upland & 430 & 0 & 0 & 0 & 494.56 & 0.00 \\
\hline 97. & Podunajská rovina Plain & 790 & 0 & 0 & 0 & 3492.44 & 0.00 \\
\hline 98. & Burda Mts & 420 & 0 & 0 & 0 & 26.24 & 0.00 \\
\hline
\end{tabular}



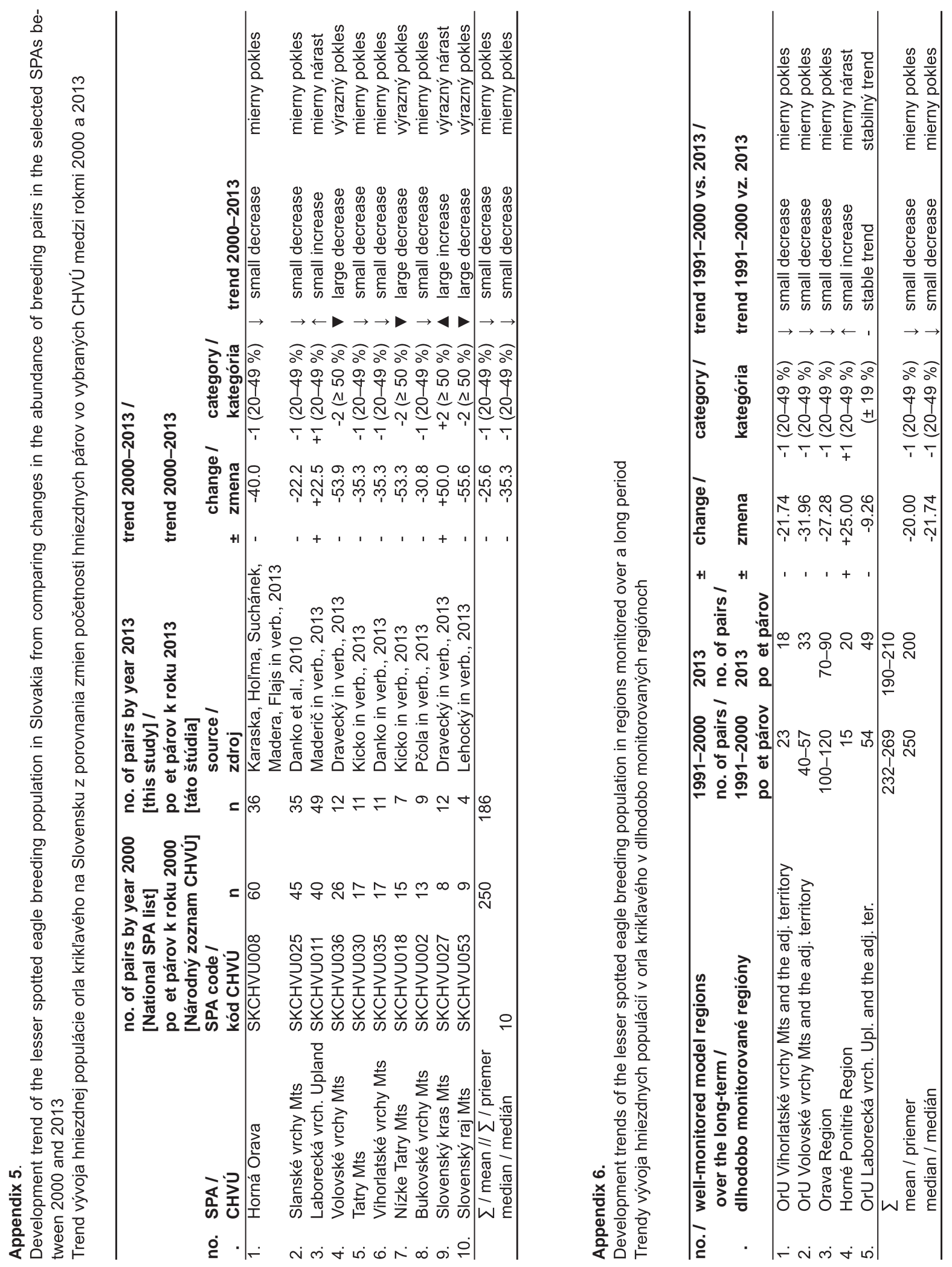
Slovak Raptor Journal 2015, 9: 7-44. DOI: 10.1515/srj-2015-0001.

(C) Raptor Protection of Slovakia (RPS)

\section{Appendix 7.}

Summary statistics and interval estimates of densities of the lesser spotted eagle in eight SPAs by 2013 (calculated in the DFS grid squares; $n=119$ )

Sumárna štatistika a intervalové odhady denzít orla kriklavého v 8 CHVÚ v roku 2013 (počítané v sieti kvadrátov DFS; $n=119$ )

\begin{tabular}{|c|c|c|c|c|c|c|}
\hline SPA / CHVÚ & mean / priemer & 95\%LCL & 95\%UCL & median / medián & 95\%LCL & 95\%UCL \\
\hline Laborecká vrchovina Upland & 4.5 & 1.7 & 7.4 & 2.9 & 0.0 & 5.4 \\
\hline Horná Orava & 6.3 & 1.0 & 11.6 & 6.4 & 0.0 & 8.0 \\
\hline Slanské vrchy Mts - south / juh & 6.0 & 3.1 & 8.9 & 5.6 & 3.3 & 9.6 \\
\hline Slovenský kras Mts & 2.5 & 0.0 & 5.0 & 1.3 & 0.0 & 3.3 \\
\hline Volovské vrchy Mts & 1.2 & 0.1 & 2.4 & 0.0 & 0.0 & 1.0 \\
\hline Tatry Mts & 2.0 & -1.2 & 5.3 & 0.0 & 0.0 & 2.3 \\
\hline Vihorlatské vrchy Mts & 2.3 & 0.2 & 4.3 & 0.0 & 0.0 & 5.6 \\
\hline Nízke Tatry Mts & 1.4 & -0.1 & 2.9 & 0.0 & 0.0 & 0.0 \\
\hline mean/ priemer & 3.3 & 0.6 & 5.9 & 2.2 & 0.4 & 4.4 \\
\hline $95 \%$ LCL & 1.6 & & & -0.2 & & \\
\hline $95 \%$ UCL & 5.0 & & & 4.3 & & \\
\hline weighted mean / vážený priemer & 3.1 & & & 1.8 & & \\
\hline median / medián & 2.4 & & & 0.7 & & \\
\hline $95 \% L C L$ & 1.2 & & & 0.0 & & \\
\hline $95 \%$ UCL & 6.0 & & & 5.6 & & \\
\hline
\end{tabular}

Legend / Vysvetlivky:

$95 \%$ LCL - lower $95 \%$ confidence limit / dolná medza $95 \%$-ného intervalu spol'ahlivosti

$95 \%$ UCL - upper $95 \%$ confidence limit / horná medza $95 \%$-ného intervalu spol'ahlivosti 


\section{Appendix 8.}

Sources of comparison of the number of breeding pairs in individual countries of the lesser spotted eagle breeding distribution range in Europe.

Zdroje porovnávania počtu hniezdnych párov v jednotlivých krajinách areálu hniezdneho rozšírenia orla kriklavého v Európe.

\begin{tabular}{|c|c|c|c|c|}
\hline source / zdroj & $\begin{array}{c}1 \\
\text { Meyburg et al. (2001) }\end{array}$ & $\begin{array}{c}2 \\
\text { Meyburg (1996) }\end{array}$ & $\begin{array}{c}3 \\
\text { BirdLife (2004) }\end{array}$ & $\begin{array}{c}4 \\
\text { Krumenacker (2013) }\end{array}$ \\
\hline country / krajina & $\begin{array}{l}\text { no. of pairs / } \\
\text { počet párov }\end{array}$ & $\begin{array}{l}\text { no. of pairs / } \\
\text { počet párov }\end{array}$ & $\begin{array}{l}\text { no. of pairs / } \\
\text { počet párov }\end{array}$ & $\begin{array}{l}\text { no. of pairs / } \\
\text { počet párov }\end{array}$ \\
\hline Albania & & & $2-10$ & $2-10$ \\
\hline Armenia & $35-40$ & 50 & $20-30$ & $48-52$ \\
\hline Azerbaijan & 100 & & $20-100$ & $20-100$ \\
\hline Belarus & $3,250 \pm 100$ & & $3,200-3,800$ & $3,200-3,800$ \\
\hline Bosnia & 10 & & & $1-10(B+H)$ \\
\hline Bulgaria & $60-120 ?$ & & $120-200$ & 500 \\
\hline Croatia & 200 & & $60-70$ & $50-70$ \\
\hline Czech Republic & $2-5$ & & present & 1 \\
\hline Estonia & 375 & & $480-600$ & $500-600$ \\
\hline Georgia & 85 & & $10-70$ & $60-70$ \\
\hline Germany & 130 & & $134-143$ & 102 \\
\hline Greece & $60-80$ & & $67-90$ & $67-90$ \\
\hline Hungary & 150 & & $30-60$ & $40-45$ \\
\hline Iran & no data / žiadne údaje & 500 & & \\
\hline Latvia & $2,000-2,800$ & & $2,800-5,200$ & 3,600 \\
\hline Lithuania & $500-730$ & & $900-1,200$ & $1,500-1,800$ \\
\hline Macedonia & $1-2$ & & $3-10$ & $5-10$ \\
\hline Moldova & 10 & & $2-5$ & $2-5$ \\
\hline Poland & $1,660-1,850$ & & $1,700-1,900$ & $2,300-2,800$ \\
\hline Romania & $100 ?$ & & $2,500-2,800$ & $2,500-2,800$ \\
\hline Russia (European) & $\min .300 ?$ & & $300-400$ & $350-400$ \\
\hline of which Kaliningrad & $20-200$ & 200 & & $100-150$ \\
\hline North Caucasus & 50 & 500 & & $200-250$ \\
\hline Serbia and Montenegro & $23-26$ & & $20-25$ & 10-30 (Serbia) \\
\hline Slovakia & more than / viac ako 700 & & $800-900$ & $800-900$ \\
\hline Slovenia & 3 & & $2-4$ & $0-5$ \\
\hline Turkey & $300-500$ & & $80-120$ & $80-3,000$ \\
\hline Ukraine & $200-250$ & 800 & $500-1,000$ & 1,500 \\
\hline France & & & & $0-1$ \\
\hline & approximately / približne & & Total / Spolu & Total / Spolu \\
\hline$\Sigma$ & 20,000 & & $14,000-19,000$ & $18,000-23,200$ \\
\hline
\end{tabular}

